\title{
ANÁLISE DA ATIVIDADE DE ALGUMAS ENZIMAS ANTIOXIDANTES EM PLANTAS DE SOJA (Glycine max L. Merr.) SOB NÍVEIS DE MANGANÊS, EM FUNÇÃO DA MICORRIZA ARBUSCULAR
}

\section{Giuliana Castro Magalhães}

\author{
Dissertação apresentada à Escola Superior de Agricultura \\ "Luiz de Queiroz", Universidade de São Paulo, para \\ obtenção do título de Mestre em Agronomia, Área de \\ Concentração: Microbiologia Agrícola.
}

\author{
P I R A C I C A B A \\ Estado de São Paulo - Brasil \\ Julho - 2002
}




\title{
ANÁLISE DA ATIVIDADE DE ALGUMAS ENZIMAS ANTIOXIDANTES EM PLANTAS DE SOJA (Glycine max L. Merr.) SOB NÍVEIS DE MANGANÊS, EM FUNÇÃO DA MICORRIZA ARBUSCULAR
}

\section{Giuliana Castro Magalhães Bióloga}

\author{
Orientadora: Profa. Dra. ELKE J. B. N. CARDOSO
}

\begin{abstract}
Dissertação apresentada à Escola Superior de Agricultura "Luiz de Queiroz", Universidade de São Paulo, para obtenção do título de Mestre em Agronomia, Área de Concentração: Microbiologia Agrícola.
\end{abstract}

P I R A C I C A B A

Estado de São Paulo - Brasil

Julho - 2002 
Dados Internacionais de Catalogação na Publicação (CIP)
DIVISÃO DE BIBLIOTECA E DOCUMENTAÇÃO - ESALO/USP

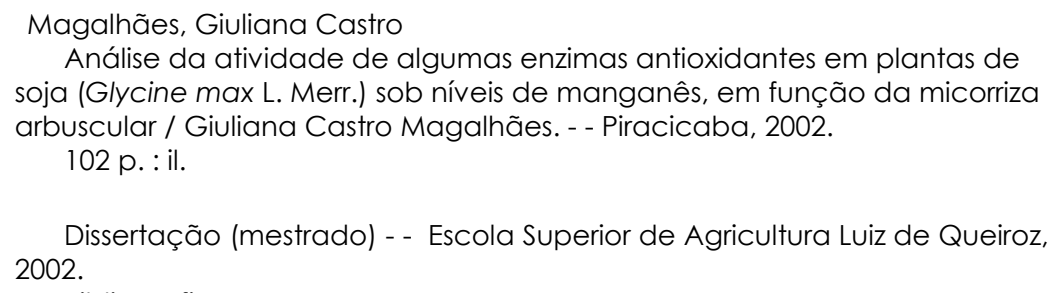

1. Enzimas 2. Manganês 3. Micorriza 4. Soja 5. Toxicidade do solo I. Título

CDD 633.34

\section{"Permitida a cópia total ou parcial deste documento, desde que citada a fonte - $\mathrm{O}$ autor"}


Aos meus queridos pais e irmã, pelo amor, apoio, dedicação, compreensão e total incentivo para realizar este trabalho.

\section{OFEREÇO}

Ao meu grande amor, pelo incentivo, apoio e compreensão. 


\section{AGRADECIMENTOS}

À Profa. Dra. Elke J.B.N. Cardoso, pela orientação, paciência e apoio durante a realização deste trabalho;

A todo Corpo Docente e demais funcionários da ESALQ/USP que proporcionaram minha formação acadêmica em Microbiologia Agrícola.

À coordenação do curso de pós-graduação em Agronomia: Microbiologia agrícola, representado pelo Prof. Flávio Cesar Almeida Tavares pela atenção, apoio e colaboração no decorrer do curso.

Ao Prof. Marcio Rodrigues Lambais pela colaboração para utilização dos equipamentos e dependências do laboratório.

Ao Prof. Ricardo Antunes de Azevedo e Prof. Luiz Antonio Gallo pelas sugestões, auxilio e contribuições.

Aos docentes, funcionários e alunos do Departamento de Solos e Nutrição de Plantas, em especial Peterson e Rogério, mesmo que de forma indireta para, pela contribuição e colaboração na realização deste trabalho no Laboratório de Microbiologia. 
Aos alunos de pós-graduação Renato, Ricardo (Depto. de Genética) e Amaral (Depto. CEBTEC) e Beto (Depto. de Genética) pelo auxílio e sugestões.

Aos amigos Marco, Lúcia e Beatriz, pelo total apoio, ensinamento, paciência e humildade.

Aos amigos do laboratório Milene, Paulo, Pereira, Denise, Leandra, Daniele, Simão, Juliano e Bete pelo companheirismo e colaboração.

Aos amigos e técnicos do Laboratório de Microbiologia Denise e Fernando, pelo auxílio, colaboração, paciência, ensinamento, confiança, companheirismo e amizade.

Ao Conselho Nacional de Pesquisas (CNPq) pela concessão da bolsa de estudo.

À minha família: pais, irmã e companheiro pelo amor, carinho, compreensão, ajuda, paciência e essencialmente o incentivo. 


\section{SUMÁRIO}

LISTA DE FIGURAS ......................................................................... ix

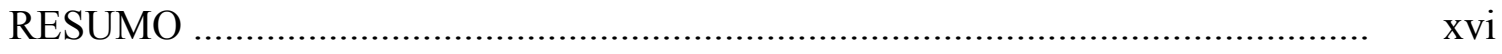

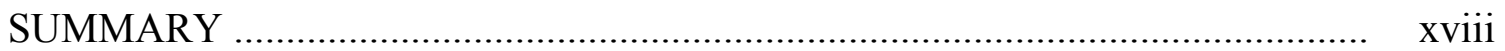

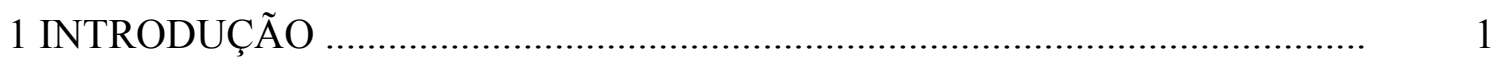

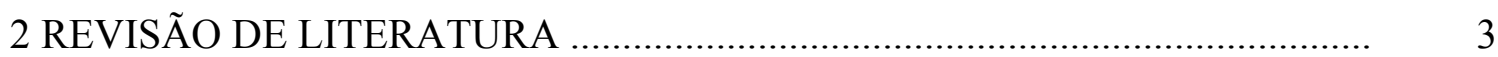

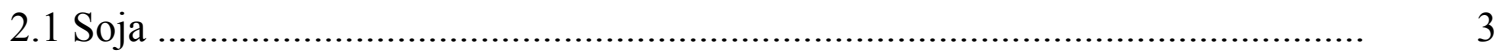

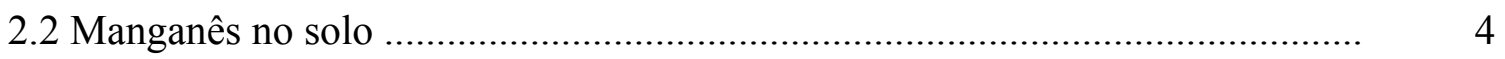

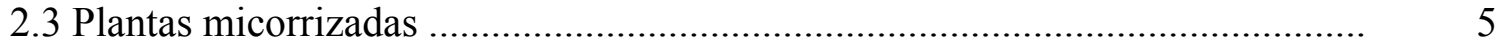

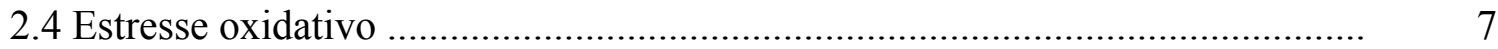

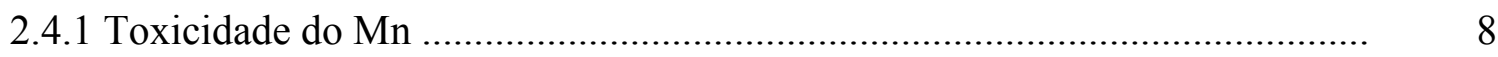

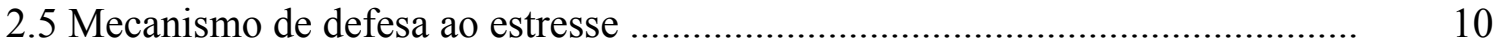

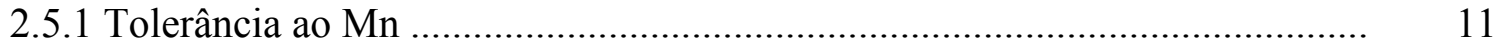

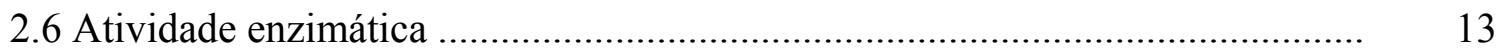

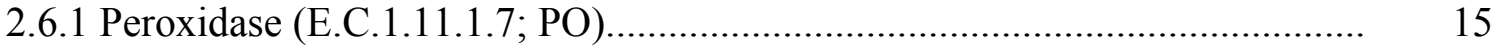

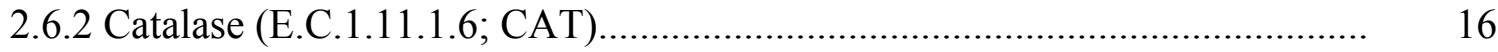

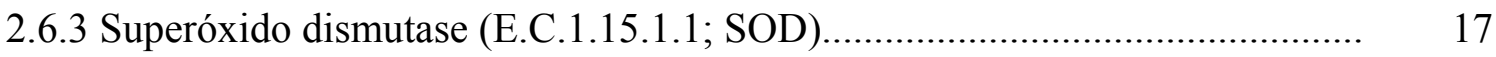

2.6.4 Oxidase de ácido indolacético (AIA- oxidase) ........................................... 19

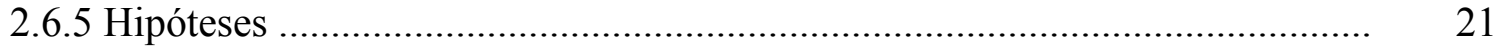

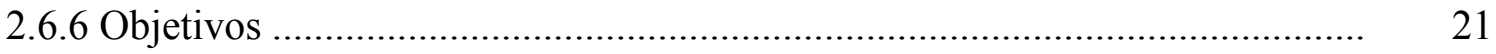

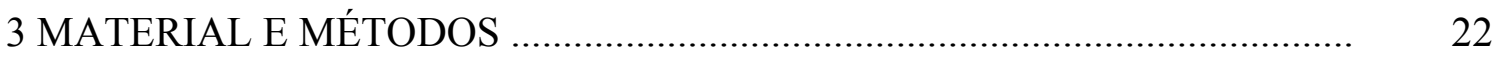

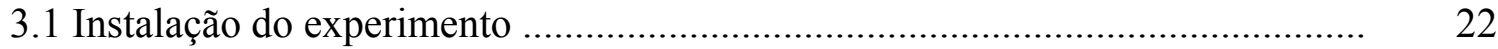

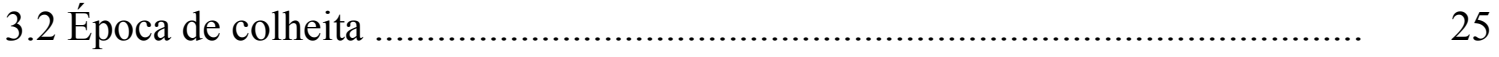


3.3 Análises laboratoriais ............................................................................... 25

3.3.1 Massa do material seco da parte aérea (MSPA) e raiz (MSR) ......................... 25

3.3.2 Determinação da concentração de nutrientes ................................................... 26

3.3.3 Porcentagem de colonização radicular ............................................................ 26

3.3.4 Extração e quantificação do micélio externo total .......................................... 27

3.3.5 Colheita do material vegetal, estocagem e extração de proteínas ................... 27

3.3.6 Determinação de proteínas .............................................................................. 28

3.3.7 Atividade enzimática ................................................................................ 28

3.3.7.1 Catalase (E.C.1.11.1.6; CAT) ............................................................. 28

3.3.7.2 Oxidase do ácido indolácético (AIA- oxidase).............................................. 29

3.3.7.3 Peroxidase (E.C.1.11.1.7; PO) .............................................................. 29

3.3.7.4 Superóxido dismutase (E.C.1.15.1.1; SOD) ............................................. 30

3.4 Análise estatística ..................................................................................... 30

4 RESULTADOS E DISCUSSÃO ................................................................ 31

4.1 Sintomas de toxicidade de $\mathrm{Mn}$.................................................................. 31

4.2 Massa do material seco da parte aérea e raiz ……………………………........ 35

4.3 Colonização radicular ............................................................................... 38

4.4 Comprimento do micélio extrarradicular (MET) …………............................. 40

4.5 Análise dos nutrientes ............................................................................ 42

4.5.1 Fósforo na parte aérea e raiz.........................................................................

4.5.2 Cálcio na parte aérea e raiz........................................................................... 44

4.5.3 Ferro na parte aérea e raiz....................................................................... 46

4.5.4 Manganês na parte aérea e raiz.................................................................... 48

4.6 Análise da atividade enzimática ................................................................... 54

4.6.1 Atividade de Peroxidase ............................................................................. 54

4.6.1.1 Folha ..........................................................................................

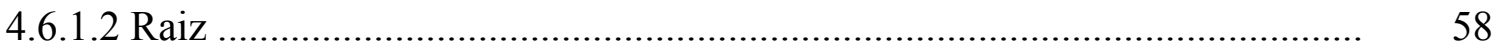

4.6.2 Atividade de oxidase de ácido indolacético .................................................... 66

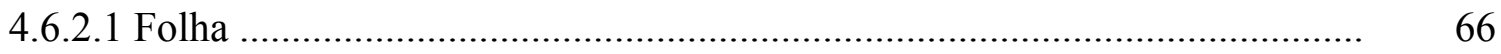


4.6.2.2 Raiz 70

4.6.3 Atividade de superóxido dismutase 74

4.6.4 Atividade de catalase 81 5 CONCLUSÕES 82 REFERÊNCIAS BIBLIOGRÁFICAS 84 


\section{LISTA DE FIGURAS}

Página

1 Aspecto da face adaxial e abaxial de trifólios de soja sadios (da esquerda) e lesionados (da direita) com sintomas de toxidez de Mn dez dias após o plantio.

2 Aspecto da manifestação dos sintomas de toxidez de Mn em plantas de soja aos 45 dias ( $1^{\text {a }}$ colheita), de acordo com os tratamentos de micorrização e não micorrização nas cinco doses de Mn adicionadas ao substrato (mg $\left.\mathrm{kg}^{1}\right)$.

3 Aspecto da manifestação dos sintomas de toxidez de Mn em plantas de soja aos 90 dias ( $2^{\text {a }}$ colheita), de acordo com os tratamentos de micorrização e não micorrização nas cinco doses de Mn adicionadas ao substrato (mg $\left.\mathrm{kg}^{1}\right)$

4 Análise de regressão polinomial para matéria seca total (MST) de plantas de soja inoculadas ou não com FMAs e submetidas a doses crescentes de Mn, respectivamente aos 45 e 90 dias.

5 Matéria seca total de plantas de soja inoculadas ou não com FMAs e submetidas a doses crescentes de Mn aos 90 dias. Letras diferentes indicam diferenças significativas pelo teste de Tukey (5\%) 
6 Colonização radicular de plantas de soja inoculadas com FMAs e submetidas a doses crescentes de $\mathrm{Mn}$ aos 45 e 90 dias. Letras diferentes

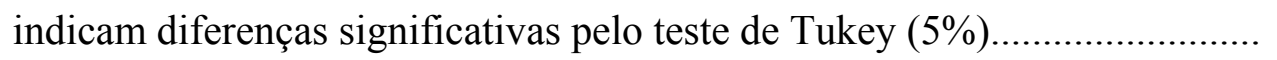

7 Análise de regressão polinomial para colonização radicular de plantas de soja inoculadas com FMAs e submetidas a doses crescentes de Mn aos 45 dias e 90 dias.

8 Comprimento de micélio extrarradicular total (MET) de plantas de soja inoculadas ou não com FMAs e submetidas a doses crescentes de Mn aos 45 dias. Letras diferentes indicam diferenças significativas pelo teste de Tukey $(5 \%)$

9 Análise de regressão polinomial para o comprimento de micélio extrarradicular total (MET) de plantas de soja inoculadas ou não com FMAs e submetidas a doses crescentes de Mn aos 45 dias

10 Concentração de P na parte aérea de plantas de soja inoculadas ou não com FMAs e submetidas a doses crescentes de Mn aos 90 dias. Letras diferentes indicam diferenças significativas pelo teste de Tukey $(5 \%)$

11 Análise de regressão polinomial para a concentração de $\mathrm{P}$ na parte aérea de plantas de soja inoculadas ou não com FMAs e submetidas a doses crescentes de Mn aos 45 e 90 dias.

12 Análise de regressão polinomial para a concentração de Ca na parte aérea de plantas de soja inoculadas ou não com FMAs e submetidas a doses crescentes de Mn aos 90 dias 
13 Concentração de Fe na parte aérea de plantas de soja inoculadas ou não com FMAs e submetidas a doses crescentes de Mn aos 90 dias. Letras diferentes indicam diferenças significativas pelo teste de Tukey $(5 \%)$

14 Análise de regressão polinomial para a concentração de Fe na parte aérea de plantas de soja inoculadas ou não com FMAs e submetidas a doses crescentes de $\mathrm{Mn}$ aos 45 dias e 90 dias.

15 Concentração de Mn na parte aérea de plantas de soja inoculadas ou não com FMAs e submetidas a doses crescentes de Mn aos 45 dias. Letras diferentes indicam diferenças significativas pelo teste de Tukey $(5 \%)$

16 Análise de regressão polinomial para a concentração de Mn na parte aérea de plantas de soja inoculadas ou não com FMAs e submetidas a doses crescentes de Mn aos 45 dias.

17 Concentração de Mn na parte aérea de plantas de soja inoculadas ou não com FMAs e submetidas a doses crescentes de Mn aos 90 dias. Letras diferentes indicam diferenças significativas pelo teste de Tukey $(5 \%)$

18 Análise de regressão polinomial para a concentração de Mn na parte aérea de plantas de soja inoculadas ou não com FMAs e submetidas a doses crescentes de Mn aos 90 dias. 
19 Análise de regressão polinomial para a concentração de Mn na raiz de plantas de soja inoculadas ou não com FMAs e submetidas a doses crescentes de Mn aos 45 dias

20 Análise de regressão polinomial para a concentração de $\mathrm{Mn}$ na raiz de plantas de soja inoculadas ou não com FMAs e submetidas a doses crescentes de Mn aos na 90 dias

21 Concentração de $\mathrm{Mn}$ na raiz de plantas de soja inoculadas ou não com FMAs e submetidas a doses crescentes de Mn aos 90 dias. Letras diferentes indicam diferenças significativas pelo teste de Tukey $(5 \%)$

22 Padrão eletroforético em gel de poliacrilamida para peroxidase com extrato foliar de plantas de soja, que receberam duas doses de P (controles P1 e P2) e inoculadas com os FMAs Glomus etunicatum (Ge) e Glomus macrocarpum $(\mathrm{Gm})$ em dose P1, após 45 dias de crescimento nas doses 0 , 20 e $40 \mathrm{mg} \mathrm{kg}^{-1}$ de $\mathrm{Mn}$ adicionado ao substrato. As setas indicam a posição das principais isoformas

23 Padrão eletroforético em gel de poliacrilamida para peroxidase com extrato foliar de plantas de soja, que receberam duas doses de P (controles P1 e P2) e inoculadas com os FMAs Glomus etunicatum (Ge) e Glomus macrocarpum $(\mathrm{Gm})$ em dose $\mathrm{P} 1$, após 90 dias de crescimento nas doses 0 , 20 e $40 \mathrm{mg} \mathrm{kg}^{-1}$ de $\mathrm{Mn}$ adicionado ao substrato. As setas indicam a posição das principais isoformas...... 
24 Padrão eletroforético em gel de poliacrilamida para peroxidase com extrato de raiz de plantas de soja, que receberam duas doses de P (controles P1 e P2) e inoculadas com os FMAs Glomus etunicatum (Ge) e Glomus macrocarpum $(\mathrm{Gm})$ em dose P1, após 45 dias de crescimento nas doses 0 , 20 e $40 \mathrm{mg} \mathrm{kg}^{-1}$ de $\mathrm{Mn}$ adicionado ao substrato. As setas indicam a posição das principais isoformas

25 Padrão eletroforético em gel de poliacrilamida para peroxidase com extrato de raiz de plantas de soja, que receberam duas doses de P (controles P1 e P2) e inoculadas com os FMAs Glomus etunicatum (Ge) e Glomus macrocarpum $(\mathrm{Gm})$ em dose P1, após 90 dias de crescimento nas doses 0 , 20 e $40 \mathrm{mg} \mathrm{kg}^{-1}$ de $\mathrm{Mn}$ adicionado ao substrato. As setas indicam a posição das principais isoformas

26 Padrão eletroforético em gel de poliacrilamida para oxidase de AIA com extrato foliar de plantas de soja, que receberam duas doses de $\mathrm{P}$ (controles P1 e P2) e inoculadas com os FMAs Glomus etunicatum (Ge) e Glomus macrocarpum $(\mathrm{Gm})$ em dose P1, após 45 dias de crescimento nas doses 0 , 20 e $40 \mathrm{mg} \mathrm{kg}^{-1}$ de $\mathrm{Mn}$ adicionado ao substrato. As setas indicam a posição das principais isoformas......

27 Padrão eletroforético em gel de poliacrilamida para oxidase de AIA com extrato foliar de plantas de soja, que receberam duas doses de $\mathrm{P}$ (controles P1 e P2) e inoculadas com os FMAs Glomus etunicatum (Ge) e Glomus macrocarpum $(\mathrm{Gm})$ em dose P1, após 90 dias de crescimento nas doses 0 , 20 e $40 \mathrm{mg} \mathrm{kg}^{-1}$ de $\mathrm{Mn}$ adicionado ao substrato. As setas indicam a posição das principais isoformas 
28 Padrão eletroforético em gel de poliacrilamida para oxidase de AIA com extrato de raiz de plantas de soja, que receberam duas doses de $\mathrm{P}$ (controles P1 e P2) e inoculadas com os FMAs Glomus etunicatum (Ge) e Glomus macrocarpum $(\mathrm{Gm})$ em dose $\mathrm{P} 1$, após 45 dias de crescimento nas doses 0 , 20 e $40 \mathrm{mg} \mathrm{kg}^{-1}$ de $\mathrm{Mn}$ adicionado ao substrato. As setas indicam a posição das principais isoformas

29 Padrão eletroforético em gel de poliacrilamida para oxidase de AIA com extrato de raiz de plantas de soja, que receberam duas doses de $\mathrm{P}$ (controles P1 e P2) e inoculadas com os FMAs Glomus etunicatum (Ge) e Glomus macrocarpum $(\mathrm{Gm})$ em dose P1, após 90 dias de crescimento nas doses 0 , 20 e $40 \mathrm{mg} \mathrm{kg}^{-1}$ de $\mathrm{Mn}$ adicionado ao substrato. As setas indicam a posição das principais isoformas

30 Padrão eletroforético em gel de poliacrilamida para superóxido dismutase com extrato foliar de plantas de soja, que receberam duas doses de $\mathrm{P}$ (controles P1 e P2) e inoculadas com os FMAs Glomus etunicatum (Ge) e Glomus macrocarpum (Gm) em dose P1, após 45 dias de crescimento nas doses 0,20 e $40 \mathrm{mg} \mathrm{kg}^{-1}$ de $\mathrm{Mn}$ adicionado ao substrato. As setas indicam a posição das principais isoformas.

31 Padrão eletroforético em gel de poliacrilamida para superóxido dismutase com extrato de raiz de plantas de soja, que receberam duas doses de $\mathrm{P}$ (controles P1 e P2) e inoculadas com os FMAs Glomus etunicatum (Ge) e Glomus macrocarpum (Gm) em dose P1, após 45 dias de crescimento nas doses 0,20 e $40 \mathrm{mg} \mathrm{kg}^{-1}$ de $\mathrm{Mn}$ adicionado ao substrato. As setas indicam a posição das principais isoformas 
32 Padrão eletroforético em gel de poliacrilamida para superóxido dismutase com extrato foliar de plantas de soja, que receberam duas doses de $\mathrm{P}$ (controles P1 e P2) e inoculadas com os FMAs Glomus etunicatum (Ge) e Glomus macrocarpum (Gm) em dose P1, após 90 dias de crescimento nas doses 0,20 e $40 \mathrm{mg} \mathrm{kg}^{-1}$ de $\mathrm{Mn}$ adicionado ao substrato. As setas indicam

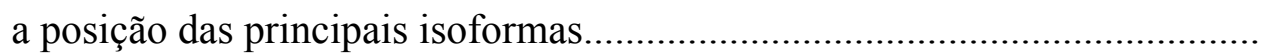

33 Padrão eletroforético em gel de poliacrilamida para superóxido dismutase com extrato de raiz de plantas de soja, que receberam duas doses de $\mathrm{P}$ (controles P1 e P2) e inoculadas com os FMAs Glomus etunicatum $(\mathrm{Ge})$ e Glomus macrocarpum (Gm) em dose P1, após 90 dias de crescimento nas doses 0,20 e $40 \mathrm{mg} \mathrm{kg}^{-1}$ de $\mathrm{Mn}$ adicionado ao substrato. As setas indicam

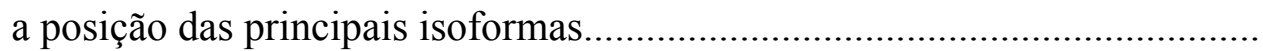




\title{
ANÁLISE DA ATIVIDADE DE ALGUMAS ENZIMAS ANTIOXIDANTES EM PLANTAS DE SOJA (Glycine max L. Merr.) SOB NÍVEIS DE MANGANÊS, EM FUNÇÃO DA MICORRIZA ARBUSCULAR
}

\author{
Autora: GIULIANA CASTRO MAGALHÃES \\ Orientadora: Profa. Dra. ELKE J.B.N. CARDOSO
}

\section{RESUMO}

Os solos brasileiros são predominantemente ácidos, ocorrência comum nas regiões tropicais. Esta condição, aliada a outros fatores abióticos e bióticos, pode resultar em toxicidade de manganês $(\mathrm{Mn})$ às plantas, o que limita o seu desenvolvimento. A utilização de práticas agrícolas convencionais propicia o aumento da toxidez de $\mathrm{Mn}$, à medida que reduz o teor de matéria orgânica. Para atenuar este problema, algumas práticas como a calagem e o melhoramento genético são amplamente utilizados. Entretanto, a utilização de alternativas de manejo da cultura através do uso da simbiose micorrízica, para induzir maior resistência das plantas a altos níveis de Mn, parece bastante promissora. Para investigar possíveis mecanismos de indução da resistência e interações de nutrientes no controle da toxicidade de Mn em soja, foram avaliados o crescimento, a absorção e a acumulação de $\mathrm{Mn}, \mathrm{Fe}, \mathrm{P}$ e Ca e a atividade de catalase, peroxidase, superóxido dismutase e oxidase de AIA, nas folhas e raízes das plantas micorrizadas e não micorrizadas, além do nível de colonização de raízes pelo fungo micorrízico arbuscular (FMA). A planta teste foi a soja (Glycine max L. Merr. CV. IAC 8-2). O experimento foi executado em casa de vegetação, em vasos 
preenchidos com $4 \mathrm{Kg}$ de solo classificado como Neossolo Quartzarênico típico, previamente autoclavado para eliminar fungos micorrízicos arbusculares. $\mathrm{O}$ delineamento foi inteiramente casualizado, em esquema fatorial, 4x5: dois isolados de FMA, Glomus etunicatum e Glomus macrocarpum, cada qual com $30 \mathrm{mg} \mathrm{kg}^{-1} \mathrm{de} \mathrm{P}$ adicionado ao substrato e dois controles não inoculados, sendo um com $30 \mathrm{mg} \mathrm{kg}^{-1} \mathrm{e}$ outro com $50 \mathrm{mg} \mathrm{kg}^{-1}$ de $\mathrm{P}, 5$ níveis de $\mathrm{Mn}\left(0,5,10,20,40 \mathrm{mg} \mathrm{kg}^{-1}\right)$. Foram realizadas duas épocas distintas de colheita, aos 45 e 90 dias. As atividades enzimáticas foram avaliadas pelo método PAGE não-denaturante através de análise visual. Os resultados demonstram que níveis de $\mathrm{Mn}$ entre 10 e $40 \mathrm{mg} \mathrm{kg}^{-1}$ no substrato podem induzir respostas de toxidez de $\mathrm{Mn}$ em plantas de soja, acompanhadas de redução de crescimento e alterações no padrão de absorção de vários nutrientes vegetais. $\mathrm{O}$ aumento da dose de $\mathrm{P}$ e a presença da micorriza são fatores de atenuação da toxidez de $\mathrm{Mn}$ em soja, visto que plantas micorrizadas contêm menor concentração de Mn em seus tecidos e, de uma maneira geral, menor atividade enzimática de peroxidase (PO) e oxidase do ácido-indolacético (AIA) do que as plantas controles. Aumentos no nível de Mn do substrato podem causar um aumento da atividade de PO e de oxidase de AIA nas plantas, sendo que as plantas mais estressadas quase sempre apresentam maior atividade dessas enzimas. Apesar da superóxido dismutase (SOD) ser também enzima antioxidativa, apresenta um padrão eletroforético diferenciado da PO, sendo que na raiz sua maior atividade está correlacionada com a presença do FMA. 


\title{
ACTIVITY ANALIYSIS OF SOME ANTIOXIDANT ENZYMES IN SOYBEAN PLANTS (Glycine max L. Merr.) UNDER LEVELS OF MANGANESE, IN FUNCTION OF ARBUSCULAR MYCORRHIZAE
}

\author{
Author: GIULIANA CASTRO MAGALHÃES
}

Adviser: Prof. ELKE J.B.N. CARDOSO

\section{SUMMARY}

Brazilian soils are predominantly acid, which is considered a common incident in tropical regions. Soil acidity in combination with biotic and non-biotic factors can result manganese toxicity in plants, limiting their development. The use of conventional agricultural practices promotes an increase in Mn toxicity, as it reduces the soil content of organic matter. This problem can be minimized by the use of some tilling practicies like liming and breeding, which are widely used. However, crop management alternatives through the use of mycorrhizae to induce greater Mn tolerance in plants under high levels of $\mathrm{Mn}$ seem to be promising. In this work, plant growth, the absorption, distibution of $\mathrm{Mn}, \mathrm{Fe}, \mathrm{P}, \mathrm{Ca}$ and activity of catalase, peroxidase, superoxide dismutase and indolacetic acid oxidase were evaluated in leaves and roots of plants inoculated with mycorrhizal fungi and non-inoculated ones, to invetigate a possible resistance induction mechanism and nutrient interactions in control of toxic levels of Mn. A greenhouse experiment was conducted with soybean plant (Glycine max L. Merr. $\mathrm{CV}$. IAC 8-2) in a completely randomized factorial design $4 \times 5$ : inoculation of two 
different arbuscular mycorrhizal fungi (AMF): Glomus etunicatum and Glomus macrocarpum, which received $30 \mathrm{mg} \mathrm{kg}^{-1}$ of $\mathrm{P}$, and two non-inoculated controls, one that received $30 \mathrm{mg} \mathrm{kg}^{-1}$ and the other with $50 \mathrm{mg} \mathrm{kg}^{-1}$ of $\mathrm{P} ; 5$ levels of $\mathrm{Mn}(0,5,10$, 20, $40 \mathrm{mg} \mathrm{kg}^{-1}$ ). There were two harvest periods, 45 and 90 days. The enzymatic activities were evaluated in non-denaturing polyacrilamyde gel eletrophoresis (PAGE). Manganese levels between 10 and $40 \mathrm{mg} \mathrm{kg}^{-1}$ in the substrate can induce Mn toxicity in soybean plants, that results in a growth reduction and in alterations in the nuttrient absorption alterations of the plants. The increase of $\mathrm{P}$ and the presence of mycorrhizae result in the alleviation of $\mathrm{Mn}$ toxicity in soybean plants. Micorrhizal plants present lower Mn concentration and generally less enzymatic activity of indolacetic acid oxidase and peroxidase than control plants. Although both, peroxidase and superoxide dismutase are antioxidant enzymes, they present differentiated electrophoretic standards. Most of the time peroxidase and indolacetic acid oxidase activities increase due to increasing $\mathrm{Mn}$ levels. Superoxide dismutase activity, however, is higher in the shoots of micorrhizal plants when compared to control plants. 


\section{INTRODUÇÃO}

Os solos ácidos, que são predominantes no Brasil, dependendo da interação entre fatores abióticos e bióticos, podem resultar em toxicidade de manganês $(\mathrm{Mn})$ às plantas, o que limita o desenvolvimento vegetal.

O manganês na planta é um cofator e ativador de várias enzimas que participam em diferentes processos metabólicos. A sua toxicidade pode torná-lo um fator estressante, provocando a formação de radicais livres, que causam alterações na atividade metabólica (como na absorção e na distribuição de nutrientes) e induzem a ativação de processos antioxidativos com alterações das atividades enzimáticas nas plantas.

As condições nutricionais e ambientais influenciam diretamente o desenvolvimento das plantas. Plantas em interação com fungos micorrízicos arbusculares (FMAs) apresentam padrão diferencial de desenvolvimento anatômico, fisiológico, de atividade enzimática, de absorção, distribuição de $\mathrm{Mn}$ e de outros nutrientes quando comparadas a plantas sem FMAs. Na maioria dos casos relatados em literatura, as plantas micorrizadas absorvem maior quantidade de $\mathrm{P}$ e apresentam concentrações de Mn significativamente mais baixas.

Especificamente no caso do $\mathrm{P}$, em experimentos que visem avaliações fisiológicas da planta, recomenda-se que se adicione ao controle sem FMA, maior dose de $\mathrm{P}$, para que sejam compensados os efeitos causados pela micorrização sobre a absorção de $\mathrm{P}$, eliminando assim o efeito de melhor estado nutricional e conseqüentemente maior crescimento de plantas micorrizadas (Pacovsky et al., 1986). Pode-se inferir, então, que o estado fisiológico e bioquímico da planta poderá ser 
diferenciado de acordo com o seu estado de micorrização, em função da influência dos fungos micorrízicos.

A cultura da soja tem sido considerada como exigente em altos investimentos na melhoria da fertilidade do solo. Hoje a biotecnologia e prática de manejo ideal para uma agricultura sustentável estão assumindo maior importância na agricultura. Para isto estão sendo conduzidos programas de melhoramento genético e práticas de manejo alternativo, como a reposição e o acréscimo da matéria orgânica do solo, como uma forma de atenuar os problemas de toxidez de Mn.

De fato, os mecanismos envolvidos na tolerância ao Mn são determinados geneticamente e, portanto, germoplasma de importância agrícola que não possua estes genes será suscetível a altos níveis de Mn no solo. No caso da matéria orgânica, como é fonte de energia para os microrganismos do solo, seu teor pode apresentar um efeito indireto sobre a disponibilidade de $\mathrm{Mn}$, por influenciar a atividade dos microrganismos envolvidos na sua oxi-redução e o efeito direto por formar complexos de Mn com a matéria orgânica do solo, tornando-o menos disponível para as plantas. Visto que em práticas de agricultura convencional, o conteúdo de matéria orgânica dos solos é reduzido, a toxidez de $\mathrm{Mn}$ pode tornar-se mais acentuada na maioria dos solos agrícolas de uso intensivo.

Uma possibilidade de atenuação do efeito da toxicidade de Mn é a inoculação de plantas com um isolado apropriado de fungo micorrízico arbuscular (FMA), que seja compatível com a espécie ou a cultivar, de modo a aumentar sua resistência a altos níveis de Mn no solo (Cardoso, 1996a). Portanto, parece ser bastante promissora a prática de manejo da cultura através do uso da simbiose micorrízica, para induzir maior resistência das plantas a altos níveis de Mn. 


\section{REVISÃO DE LITERATURA}

\subsection{Soja}

A soja, é uma espécie diplóide (2n) com 40 cromossomos, autógama, anual (Kiang \& Gorman, 1983), herbácea, cuja posição taxonômica se insere na subdivisão Angiospermae, classe Dicotyledoneae, ordem Rosales, família Leguminosae, subfamília Papilionaceae, tribo Phaseoleae, gênero Glycine L. e a espécie estudada foi Glycine max (L.) Merrill (Carlson, 1973). É uma planta de grande importância econômica, apresentando inúmeras utilizações, como adubação verde, alimentação humana, nutrição animal e usos industriais.

Tem como centro de origem a China, tendo sido primeiramente introduzida no Brasil, na Bahia, em 1882, sem sucesso. À medida que se constataram as excelentes possibilidades para a cultura no sul do país, intensificaram-se as pesquisas (Câmara, 1998). Atualmente, a produção de soja concentra-se na região Sudeste, Sul (São Paulo, Paraná, Santa Catarina e Rio Grande do Sul) e região Centro-Oeste (Minas Gerais, Goiás, Mato Grosso do Sul, Mato Grosso e Distrito Federal) (Embrapa, 1999).

O Brasil é o segundo maior produtor de soja do mundo, sendo superado apenas pelos EUA (Embrapa, 1999). Além disso, a soja é o principal produto nas exportações de produtos agropecuários (Margarido \& Souza, 1998). 


\subsection{Manganês no solo}

A toxidez de Mn pode ser um fator limitante para o desenvolvimento de plantas em solos ácidos (Foy, 1984). Isto ocorre predominantemente em regiões tropicais (Camargo, 1988), mas também pode aparecer em solos com aeração deficiente, úmidos ou compactados, de clima temperado. O teor total de manganês é variado em diferentes solos e ocorre em diversas formas de minerais, como pirolusita $\left(\mathrm{MnO}_{2}\right)$ e manganita $(\mathrm{MnO}(\mathrm{OH}))$. Apenas uma pequena fração do manganês total no solo está disponível para as plantas (Miyazawa et al., 1993). O manganês divalente geralmente é a forma prevalente na solução do solo, sendo a mais assimilada pelas plantas (Marschner, 1986).

O manganês interage com vários outros elementos minerais na nutrição vegetal, especialmente o P (Olsen, 1972), que tem grande efeito no estabelecimento e no funcionamento de simbioses micorrízicas (Cardoso, 1996a). Neste caso, a diferença na assimilação e utilização de $\mathrm{P}$ afetaria a assimilação de Mn. Por estas razões, é interessante trabalhar com diferentes níveis de $\mathrm{P}$ para determinar se estas variáveis interferem diretamente na acumulação de $\mathrm{Mn}$.

As características do solo, como pH (Adams, 1984), conteúdo de matéria orgânica, atividade microbiana (Cardoso, 1996b) e umidade (Lumbanraja \& Evangelou, 1991), podem influenciar na disponibilidade do Mn. A sua disponibilidade aumenta com o decréscimo do pH (Lucas \& Knezek, 1972) e da matéria orgânica (Foy et al., 1978), podendo atingir níveis tóxicos para as plantas nestas condições. Outro fator importante para o aumento da disponibilidade do Mn é a própria planta, pois a exsudação de compostos orgânicos pelas raízes, como o ácido málico, e sua oxidação podem aumentar a solubilidade de $\mathrm{Mn}$ pela redução de $\mathrm{Mn}^{+4}\left(\mathrm{MnO}_{2}\right)$ e formação de $\mathrm{Mn}^{+2}$ (Godo \& Reisenauer, 1980).

Em solos calcáreos, em reposta ao estresse de Fe, algumas plantas eliminam $\mathrm{H}^{+}$e compostos reduzidos, aumentando as taxas de redução de $\mathrm{Fe}^{3+}$ a $\mathrm{Fe}^{2+}$, o que também levaria a um aumento da disponibilidade de $\mathrm{Mn}^{2+}$ (Moraghan, 1979). Em solos ácidos, íons $\mathrm{Mn}^{+3}$ e $\mathrm{Mn}^{+4}$ são liberados pelos óxidos, sesquióxidos e dióxidos de 
Mn, predominando o $\mathrm{Mn}^{+2}$ (Horst, 1988). Em solos encharcados, onde predominam os processos redutores, se houver altos teores de Mn total, a sua disponibilidade pode facilmente atingir níveis tóxicos (Adams, 1984; Horst, 1988).

O Mn também forma complexos com a matéria orgânica do solo, o que o torna menos disponível para as plantas. Visto que o conteúdo de matéria orgânica dos solos é reduzido pela maioria das práticas de agricultura convencional, a toxidez de $\mathrm{Mn}$ pode tornar-se mais acentuada na maioria dos solos agrícolas de uso intensivo (Adams, 1984). A maioria dos solos cultivados apresentam subsolo ácido, com restrição ao desenvolvimento do sistema radicular e à fixação simbiótica do nitrogênio, conseqüentemente causando um aproveitamento inadequado da água e dos nutrientes pela planta. Em solos ácidos, a toxidez do Al e do Mn é contornada com aplicações de calcário, o que também atua como suplementação de Ca e Mg. A correção de acidez nas camadas mais profundas do solo apresenta dificuldades de cunho prático, permanecendo o subsolo em condições inaptas ao crescimento das raízes para cultivares susceptíveis (Câmara, 1998).

Tipos de manejo mais modernos, como o plantio direto e a agricultura sustentável de baixo impacto, estão assumindo maior importância para a conservação, reposição e mesmo o acréscimo da matéria orgânica, como uma forma de atenuar os

problemas de toxidez de Mn. Como a matéria orgânica é fonte de energia para os microrganismos do solo, seu teor pode apresentar ainda um efeito indireto sobre a disponibilidade do $\mathrm{Mn}$, por influenciar a atividade dos microrganismos envolvidos na sua oxi-redução.

\subsection{Plantas micorrizadas}

Plantas colonizadas por fungos micorrízicos arbusculares (FMA) mostram um padrão diferencial de absorção de nutrientes quando comparadas a plantas não micorrizadas (Marschner \& Dell, 1994). Os FMAs têm impacto na fisiologia da planta hospedeira (Fries et al., 1996), com efeitos sobre a fotossíntese (Sena, 1998), 
respiração (Peng et al., 1993), função estomatal (Safir, 1987), acúmulo de C e uso de água na folha (Schwab et al., 1991).

A maioria dos trabalhos publicados enfoca a questão de efeitos no crescimento (Gilmore, 1971) ou na maior absorção de minerais pouco móveis da solução do solo (Kucey \& Janzen, 1987). A colonização micorrízica aumenta a assimilação de $\mathrm{Cu}$ (Pacovsky, 1986), Zn (Gilmore, 1971; Cardoso, 1986) e outros metais pesados (Pacovsky et al., 1985). Entretanto, vários autores demonstraram que plantas micorrizadas podem conter menores concentrações de outros nutrientes (Cardoso, 1986; 1996a; Stribley, 1987), dentre eles o Mn que, em altas concentrações, é tóxico às plantas (Marschner, 1986).

Aparentemente, o primeiro trabalho que reportou um decréscimo no teor de Mn em plantas micorrizadas foi a publicação clássica de Barbara Mosse (1957), embora o principal enfoque do trabalho tenha sido a assimilação de P. Diversos autores têm estudado mudanças na fisiologia do hospedeiro e expressão gênica decorrentes da simbiose. Pacovsky (1989) observou mudanças bioquímicas em carboidratos, proteínas, lipídios e aminoácidos em soja colonizada por FMA e sugeriu que estas mudanças estão relacionadas a variações na concentração de nutrientes.

Em solos calcáreos, onde a disponibilidade de Mn estava limitada pelo alto valor de pH, a concentração de Mn aumentou em soja micorrizada (Ross, 1971). Em outros casos, com solos arenosos (Raju et al., 1990), ácidos (Medeiros et al., 1992 a), ou em sistema hidropônico com altos níveis de Mn em solução (Medeiros et al., 1992b), a micorriza não afetou a aquisição de Mn pela planta. Entretanto, na maioria dos casos relatados na literatura, a colonização por FMAs resultou em concentrações de Mn mais baixas (Cardoso, 1986). Em soja, plantas micorrizadas acumularam significantemente menos Mn do que os controles não colonizados (Cardoso, 1985; 1996b; Pacovsky et al., 1985). 


\subsection{Estresse oxidativo}

A atmosfera da Terra com o decorrer da evolução biológica tornou-se progressivamente mais rica em $\mathrm{O}_{2}$, permitindo a evolução dos organismos aeróbios, os quais utilizam o $\mathrm{O}_{2}$ como aceptor final de elétrons durante a respiração (Scandalios, 1990; Elstner \& Osswald, 1994). Embora o $\mathrm{O}_{2}$ não seja uma molécula tão reativa, pode dar origem a estados excitados, como radicais livres, com reatividade muito maior.

O principal elemento que dá origem aos radicais livres no sistema biológico é o dioxigênio $\left(\mathrm{O}_{2}\right)$, que é uma molécula muito reativa e, embora seja essencial à vida dos organismos superiores, é um elemento perigoso se em excesso. Os radicais superóxido $\left(\mathrm{O}_{2}{ }^{\bullet-}\right)$ e hidroxila $\left(\mathrm{OH}^{\bullet}\right)$ são as espécies ativas de oxigênio (EAOs) mais importantes (Rice-Evans et al., 1991; Scandalios, 1993).

Radicais livres são essenciais para muitos processos biológicos e estão envolvidos no ciclo da oxigenase e da lipogênese. São intermediários ou produtores de reações enzimáticas, principalmente na respiração e fotossíntese e também fazem parte do evento em cascata formado em resposta a uma invasão microbiana (Rice-Evans et al., 1991). Porém, se a produção dos radicais não é controlada, podem tornar-se destrutivos para células e tecidos, podendo reagir com ácidos graxos insaturados das membranas e alterar a sua funcionalidade, diminuir a capacidade de fixação de carbono em cloroplastos, promover peroxidação de lipídios, inativação de enzimas e degradação de ácidos nucléicos (Rice-Evans et al., 1991; Sacandalios, 1993; Goodman, 1994; Mehdy, 1994).

Alguns oxidantes biologicamente importantes não são radicais, como peróxido de hidrogênio $\left(\mathrm{H}_{2} \mathrm{O}_{2}\right)$, ozônio $\left(\mathrm{O}_{3}\right)$ e oxigênio $\left(\mathrm{O}_{2}\right)$ (Bentivenga et al., 1999), mas apesar disso, podem produzir danos oxidativos em seres vivos como forma de proteção a um estresse. Tanto os radicais livres como estas espécies são denominados de espécies ativas de oxigênio (EAOs) (Rice-Evans et al., 1991).

Levitt (1972) utiliza o termo estresse para qualquer fator ambiental potencialmente desfavorável à vida de um organismo, o qual tem capacidade de resistir a 
este fator. Elstner \& Osswald (1994) utilizam o termo para descrever processos e sintomas decorrentes da exposição do indivíduo a uma situação crítica, a qual pode ou não ser tolerada. Lagriffoul et al. (1998) definiram estresse oxidativo como a somatória de todos os efeitos causados pelas EAOs.

Os radicais livres podem ser formados por fatores estressantes como radiações ultravioletas, radiações iônicas, campos magnéticos, fatores químicos (desordem nutricional e redistribuição de íons metálicos), fatores mecânicos (impacto osmótico, mudanças drásticas de temperatura e pressão) e influências biológicas que induzem a ativação dos processos oxidativos e antioxidativos (Rice-Evans et al., 1991; Elstner \& Osswald, 1994; Goodman, 1994).

A suscetibilidade ao $\mathrm{O}_{2}$ depende do organismo em estudo, de sua idade, estado fisiológico e nutricional. Os principais alvos celulares ou extracelulares para radicais reativos são as proteínas, os ácidos graxos insaturados ou os compostos lipoprotéicos, carboidratos e constituintes de DNA. Nas proteínas ocorrem a agregação e ligação cruzada, fragmentação e quebra, modificações do grupo tiol e conseqüente modificação no transporte iônico e modificação na atividade enzimática (Rice-Evans et al., 1991).

Elstner \& Osswald (1994) concluíram que radicais livres derivados de $\mathrm{O}_{2}$, como superóxido $\left(\mathrm{O}_{2}{ }^{-}\right)$, hidroxila $\left(\mathrm{OH}^{\bullet}\right)$ e o peróxido de hidrogênio $\left(\mathrm{H}_{2} \mathrm{O}_{2}\right)$ são importantes interventores da injúria celular, destruição de membranas ou alterações no sistema enzimático, pois, o $\mathrm{O}_{2}$ em suas diversas formas está diretamente envolvido com o substrato ou produto de reações controladas por enzimas (Rice-Evans et al., 1991; Goodman, 1994).

\subsubsection{Toxicidade de Mn}

Um elemento é dito tóxico quando interfere no crescimento ou metabolismo de um organismo. Todos elementos são tóxicos em alta concentração ou quando são supridos em excesso (Bowen, 1966). 
Os elementos podem ser classificados de acordo com a concentração que causa efeitos tóxicos. O Mn é classificado como moderadamente tóxico entre as concentrações de 1 e 100 ppm ( $\mathrm{mg} \mathrm{kg}^{-1}$ ) (Bowen, 1966).

Uma ação importante dos elementos tóxicos é de interferir nas enzimas. Os metais mais eletronegativos, como $\mathrm{Hg}, \mathrm{Cu}, \mathrm{Sn}, \mathrm{Pb}, \mathrm{Ni}, \mathrm{Ca}, \mathrm{Cd}, \mathrm{Fe}, \mathrm{Zn}$ e $\mathrm{Mn}$ possuem grande afinidade por grupos amino, imino e sulfidrilas, locais reativos de algumas enzimas. Os metais também podem agir em enzimas inativas, sendo absorvidos mais facilmente e utilizados para bloquear sítios ativos. Outra função essencial dos metais nas catálises bioquímicas é a redução do nitrato, a qual requer $\mathrm{Cu}, \mathrm{Fe}, \mathrm{Mn}$ e Mo e, no ciclo de Krebs, que requer $\mathrm{Fe}, \mathrm{Mg}$ e $\mathrm{Mn}$. Especificamente, o Mn é um metal ativo de fosfatotransferases, descarboxilases e ativador ou inibidor enzimático, notavelmente utilizado no ciclo de Krebs, permanece no estado divalente e não ativa oxidase ou redutase (Hewitt \& Nicholas, 1963; Bowen, 1966).

Os principais sintomas de toxicidade de $\mathrm{Mn}$ em plantas freqüentemente resultam em injúrias às paredes celulares, com o aparecimento de áreas necróticas marrons nas folhas, pecíolos e nervuras, encarquilhamento das folhas, queima das pontas das folhas e flores e rachaduras dos frutos (Hewitt \& Nicholas, 1963; Foy, 1984). Alguns sintomas de toxidez de Mn freqüentemente são observados em situações nas quais o crescimento vegetativo não chega a ser afetado. Entretanto, quando ocorre interferência neste crescimento, a parte aérea é muito mais afetada do que as raízes (Macfie et al., 1989). Os sintomas estão associados à liberação de fenóis, os quais são substratos de reações de pigmentação na presença de enzimas. Com a morte celular as fenolases latentes se tornam ativas, causando escurecimento localizado. O Mn em contato com o cloroplasto ou absorvido in vivo por plantas, pode ser oxidado ao estado mais alto de valência (Hewitt \& Nicholas, 1963).

A toxidez de Mn tem sido associada a várias alterações bioquímicas na planta, incluindo diminuição da capacidade fotossintética e crescimento retardado (Foy, 1984; Nogueira \& Cardoso, 2000), diminuição dos níveis de ácido indolacético (AIA) pelo aumento da atividade da oxidase de AIA (Morgan et al., 1976), aumento da atividade da peroxidase (Gaspar et al., 1985), desbalanço de aminoácidos (Leidi et al., 
1986), diminuição das atividades de catalase e oxidases do ácido ascórbico, menores teores de ATP e taxas de respiração (Foy, 1984).

\subsection{Mecanismos de defesa ao estresse}

Um dos problemas com que se deparam os organismos aeróbicos é a necessidade de eliminar efetivamente as EAOs, geradas durante a atividade metabólica normal e aquelas induzidas por agentes estressantes. As plantas superiores, ao longo do processo evolutivo, desenvolveram numerosos mecanismos de defesa não enzimáticos e enzimáticos eficazes na proteção de suas células contra os danos oxidativos provocados pelas EAOs (Bowler et al., 1992; Scandalios, 1993; Prasad \& Rengel, 1998). Em

processos de desintoxicação ativa, reações intermediárias do metabolismo com a desintoxicação de espécies reativas de $\mathrm{O}_{2}$ ou derivados, enzimas desintoxicantes e antioxidantes orgânicos podem ser ativados (Elstner \& Osswald, 1994).

Um dos mecanismos enzimáticos é o processo bioquímico para oxidação

do $\mathrm{Mn}^{+2}$ a $\mathrm{Mn}^{+3}$ in vivo, que visa uma paralisação dos radicais livres e pode ter várias hipóteses. Uma delas é através do sistema de peroxidase, que pode causar oxidação enzimática do $\mathrm{Mn}$ do estado divalente ou trivalente. O mecanismo está representado na reação a seguir (Hewitt \& Nicholas, 1963):

$$
\mathrm{H}_{2} \mathrm{O}_{2}+2 \mathrm{H}^{+}+2 \mathrm{Mn}^{2+} \longrightarrow 2 \mathrm{Mn}^{3+}+2 \mathrm{H}_{2} \mathrm{O}
$$

Íons livres de $\mathrm{Mn}^{3+}$ não apresentam longevidade e são rapidamente reduzidos por difenóis, catecol, pirogalol, guaiacol e ácido cafeico, voltando para o estado divalente $\left(\mathrm{Mn}^{2+}\right)$.

Entre os mecanismos não enzimáticos estão os compostos de baixa massa molecular, como glutationa reduzida (GSH), ascorbato (AsA) (Prasad \& Rengel, 1998; Asada, 1999), flavonóides, pigmentos carotenóides (Foyer et al., 1994) e fenóis (Nicholson \& Hammerschmidt, 1992 apud Elstner \& Osswald, 1994), que agem como indutores e, no caso dos compostos fenólicos, agem como cofatores dos mecanismos 
enzimáticos para regulação da atividade enzimática através da geração de enzimas antioxidantes (Scandalios, 1993; Elstner \& Osswald, 1994).

No decorrer do desenvolvimento do estresse, o limite das atividades metabólicas pode ser atingido, envolvendo estabelecimento de tolerância e desintoxicação (Elstner \& Osswald, 1994). Se o estresse é mantido por um longo período, este pode conduzir a mudanças no metabolismo, regulação e sintomas morfológicos, indicando mudanças no limite das vias anabólicas e catabólicas, podendo levar à acumulação de substâncias tóxicas ou levar à deficiência de substâncias essenciais, à injúria ou morte do organismo. Um organismo adaptado, por outro lado, pode prevenir a injúria do estresse que é removido ou diminuído a níveis que permitam o seu crescimento e desenvolvimento até completar o ciclo de vida ou se regenerar na presença deste estresse. Este tipo de adaptação é denominado "capacidade de adaptação" (Levitt, 1972).

O grau de resistência que pode ser desenvolvido de acordo com o organismo. Um dos tipos é o estresse "evitado" (“avoidance stress"), no qual a planta é capaz de excluir o estresse, parcialmente ou completamente, com a formação de uma barreira física, química ou metabólica que exclui o estresse. Outro tipo é a tolerância ao estresse, onde a planta é capaz de gerar resistência a este, podendo prevenir, diminuir ou reparar os estresses, mas sem excluí-los (Levitt, 1972).

\subsubsection{Tolerância ao Mn}

As plantas micorrizadas diferem das não-micorrizadas em aspectos fisiológicos (Peng et al., 1993) e bioquímicos (Pacovsky, 1989). Nessa simbiose também é alterada a atividade enzimática das raízes (Rosendahl, 1992), a distribuição de carboidratos (Buwalda \& Goh, 1982) e de metabólitos (Pacovsky, 1989). O decremento da assimilação de Mn (Cardoso, 1985) por plantas micorrizadas é um efeito interessante, cujo mecanismo ainda não foi explicado (Kothari et al., 1990). 
Vários mecanismos foram propostos para explicar a tolerância de $\mathrm{Mn}$ pelas plantas. Um deles envolve a compartimentalização, que sugere que os íons de Mn são depositados em compartimentos celulares menos ativos no metabolismo, tais como vacúolos e tricomas (Memon et al., 1981). Um outro mecanismo desintoxificante é a acumulação de Mn em paredes celulares secundárias (Verkleij \& Schat, 1990).

Ainda, um mecanismo de tolerância em plantas envolve a absorção e o transporte seletivo de íons, modificações nas membranas plasmáticas das raízes, ou da taxa de difusão do Mn no apoplasto, que podem limitar a absorção excessiva desse nutriente (Allan \& Jarrell, 1989). As paredes celulares de plantas micorrizadas diferem das plantas controles (Bonfante-Fasolo, 1984). Se considerarmos que é a carboximetilcelulose das paredes celulares que se liga inicialmente aos metais em solução (Allan \& Jarrell, 1989), é possível inferir que as paredes celulares de plantas micorrizadas são menos seletivas para $\mathrm{Mn}$.

Outro possível mecanismo seria a ocorrência de uma zona de alcalinização, quando as hifas absorvem $\mathrm{H}_{2} \mathrm{PO}_{4}{ }^{-}$e repõem este ânion com hidroxilas $\left(\mathrm{OH}^{-}\right)$. A condição alcalina tornaria o Mn menos disponível (Biermann \& Linderman, 1983).

Quellette \& Dessureaux (1958) apud Levitt (1972) relataram que a resistência de um clone de alfafa à toxicidade de $\mathrm{Mn}$ e de Al estaria relacionada com a retenção destes metais nas raízes. Navarro \& Cardoso (1992) observaram que, em soja cultivada em solução nutritiva com níveis crescentes de $\mathrm{Mn}$, as plantas micorrizadas apresentaram diminuição do teor desse elemento na parte aérea e aumento nas raízes. Quanto à concentração de $\mathrm{P}$, Cardoso (1996a) sugeriu que existe uma forte evidência que a concentração de $\mathrm{P}$ na parte aérea de plantas de soja pode ser um fator fundamental de interferência na acumulação de Mn nas plantas.

A cultura da soja tem sido considerada como exigente em altos investimentos na melhoria da fertilidade do solo, conduzindo os programas de melhoramento a concentrarem esforços na obtenção de genótipos mais produtivos (Câmara, 1998). De fato, os mecanismos envolvidos na tolerância ao Mn são determinados geneticamente (Kennedy \& Jones, 1991) e, portanto, germoplasma de 
importância agrícola que não possua estes genes será suscetível a altos níveis de Mn no solo. Uma possibilidade de melhoramento de germoplasma sem tolerância ao Mn é através da inoculação de plantas com um isolado apropriado de fungo micorrízico arbuscular (FMA), que seja compatível com a espécie ou a cultivar (Graham \& Sylvertsen, 1985) de modo a aumentar sua resistência a altos níveis de Mn no solo.

\subsection{Atividade Enzimática}

A toxicidade de manganês está associada a inúmeros problemas, como disfunções, distúrbios, alterações no desenvolvimento da planta e na atividade de enzimas relacionadas a estresses oxidativos (Heylar, 1978).

No processo de desintoxicação celular, a ação combinada dos sistemas enzimáticos e não enzimáticos é importante para evitar danos oxidativos celulares prejudiciais aos organismos vivos submetidos a variadas condições de estresse, pois converte os produtos potencialmente perigosos aos sistemas biológicos das EAOs (Scandalios, 1993).

O sistema de defesa enzimático é formado por enzimas capazes de remover, neutralizar ou limpar as EAOs do interior das células de organismos vivos (Scandalios, 1993). Dentre as principais enzimas antioxidantes podemos destacar a superóxido dismutase (SOD), a catalase (CAT), a peroxidase (PO) (investigadas neste trabalho) e outras, como ascorbato peroxidase (APX) e mondeidroascorbato redutase (MDAR) (Elstner \& Osswald, 1994; Prasad \& Rengel, 1998).

O manganês na planta é um cofator e ativador da atividade de várias enzimas que participam no ciclo de Krebs, de oxidases e redutases do nitrato (Helyar, 1978), dos processos de absorção iônica, fotossíntese, respiração, controle hormonal e síntese de proteínas (Malavolta et al., 1989). A atividade enzimática pode variar com a concentração do $\mathrm{Mn}$, na célula ou nas organelas de plantas, podendo controlar a atividade de absorção, excreção e transporte de outros nutrientes (Atkinson, 1966; Foy, 1984). 
O uso de isoenzimas no estudo de situações de estresse está relacionado ao entendimento das mudanças metabólicas e mecanismos de defesa, os quais ocorrem em plantas (Burdon \& Marhall, 1983).

A hipersensibilidade é um processo de infecção, no qual as células das plantas resistentes morrem e, por meio disso, isola-se o patógeno. Cada célula necrótica é comumente associada com acumulação de compostos fenólicos, aumentando a atividade de enzimas oxidativas e originando diferenças qualitativas e quantitativas no número de isoenzimas. Em estudos representativos envolvendo ataque de fungos em cevada (Savo et al., 1972 apud Burdon \& Marshall, 1983), feijão (Burdon \& Marshall, 1983) e milho (Jennings et al., 1969 apud Burdon \& Marshall, 1983) foram investigados os diferentes sistemas isoenzimáticos. Os resultados foram variados, bandas de peroxidases aumentaram em quantidade e intensidade ou não foram afetadas (Burdon \& Marshall, 1983). O aumento das atividades de enzimas relacionadas com as reações de defesa vegetal durante fase inicial da colonização intrarradicular por FMAs é acompanhado da observação dos seus transcritos (Lambais \& Mehdy, 1993; 1998), indicando ativação dos mecanismos de defesa.

Em plantas superiores, algas e cianobactérias, a superóxido dismutase, ascorbato peroxidase, glutationa peroxidase, glutationa redutase, catalase e guaiacol peroxidase podem individualmente ou cooperativamente remover o $\mathrm{O}_{2}$ reativo das espécies (Elstner \& Osswald, 1994).

Rosendahl (1992), em estudo da influência da micorriza na atividade enzimática da malato desidrogenase, glucose-6-fosfato desidrogenase, glutamatooxaloacetato transaminase e desidrogenase do glutamato, em raízes de pepino, observou, através da densitometria, que após inoculação do fungo micorrízico do gênero Glomus, ocorreram mudanças na atividade enzimática de raízes. Tanto o fungo quanto o fósforo estimularam a atividade de glucose-6-fosfato e uma das espécies de Glomus causaram diminuição da atividade da desidrogenase do glutamato na planta micorrizada.

Como a atividade enzimática é alterada pela toxicidade de manganês e esta, por sua vez, pode ser regulada pela presença de micorrizas em plantas (Rosendahl 1992; Cardoso, 1996b), pode-se inferir, então, que o padrão da atividade enzimática 
poderá ser diferenciado de acordo com o estado de micorrização da planta, em função da influência dos fungos micorrízicos.

\subsubsection{Peroxidase (E.C. 1.11.1.7; PO)}

Peroxidases (PO) são hemeproteínas de oxidorredutase, específicas para aceptor de hidrogênio (Alfenas, 1998), e estão presentes em certas células animais, em microrganismos e em tecidos vegetais. Ocorrem em diversos componentes celulares, como núcleo, mitocôndrios, ribossomos, paredes celulares e membranas celulares (Fric, 1976; Hoagland, 1990).

A reação das POs consiste de dois passos sucessivos, envolvendo um elétron cada. Uma equação geral para reações catalisadas por POs não pode ser formulada, pois o curso da reação depende do tipo de substrato, como fenóis, aminofenóis, diaminas, indofenóis, ascorbatos e diferentes aminoácidos (Bergmeyer et al., 1974). No caso em que a mesma molécula orgânica é doadora de elétrons para ambos os passos, a equação seria:

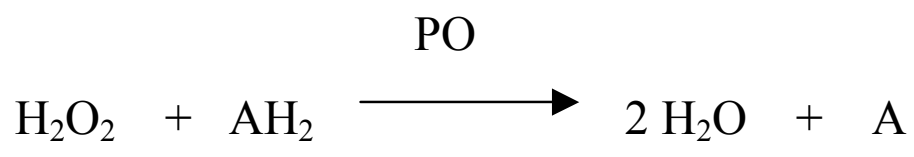

Apesar da função ainda não ser elucidada, as POs desempenham funções como a catálise da oxidação e biossíntese de lignina, gerando $\mathrm{H}_{2} \mathrm{O}_{2}$ a partir de NADH (Goldberg et al., 1985), oxidação de compostos fenólicos (Fry, 1986) e inibição do crescimento através da oxidação do ácido indol-3-acético (Hoagland, 1990).

Entre os trabalhos relacionados com a atividade de POs na presença de micorrizas, durante desenvolvimento da mesma, pode-se citar a análise de raízes de Allium porrum, as quais revelaram um incremento de atividade enzimática nas etapas 
iniciais da colonização micorrízica por Glomus versiforme (Spanu \& Bonfante-Fasolo, 1988). Fries et al. (1996) encontraram resultados semelhantes na interação Zea mays e Glomus intraradices. Mathur \& Vyas (1995) avaliaram a interação Ziziphus e Glomus fasciculatum e observaram aumentos nas atividades de POs em resposta ao incremento de $\mathrm{P}$ disponível para as plantas e à indução de isoformas presentes em vegetais e específicas pelo FMA. McArthur \& Knowles (1992; 1993), estudando padrão de atividade de POs em raízes de batata, em condições de baixo e alto $\mathrm{P}$ no solo, observaram baixo nível de atividade em raízes sob baixo $\mathrm{P}$ e indução em condições de alto $\mathrm{P}$.

\subsubsection{Catalase (E.C. 1.11.1.6; CAT)}

As CATs são enzimas de oxidorredutase, proteínas tetraédricas, constituídas de 4 grupos heme. Estão presentes em todas as células de plantas, animais e microrganismos aeróbicos (Scandalios, 1990). Podem ser encontradas no citoplasma, mitocôndrios, peroxissomos de folhas, glioxissomos de tecidos (Frugoli et al., 1996). São importantes catalisadores que atuam como reguladoras dos níveis de $\mathrm{H}_{2} \mathrm{O}_{2}$ e sua atividade consiste na conversão de $\mathrm{H}_{2} \mathrm{O}_{2}$ em $\mathrm{H}_{2} \mathrm{O}$ e $\mathrm{O}_{2}$, segundo a reação:

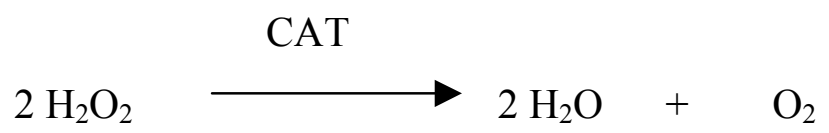

As CATs utilizam o $\mathrm{H}_{2} \mathrm{O}_{2}$ para oxidação de toxinas, incluindo compostos fenólicos, ácido fórmico, formaldeídos e álcoois (Rice-Evans et al., 1991), removem o $\mathrm{H}_{2} \mathrm{O}_{2}$ gerado nos peroxissomos foliares, pela oxidação do glicolato na fotorrespiração em plantas $\mathrm{C} 3$, e atuam também nos glioxissomos e nos mitocôndrios, combatendo o $\mathrm{H}_{2} \mathrm{O}_{2}$ produzido na $\beta$-oxidação dos ácidos graxos e na cadeia transportadora de elétrons (Frugoli et al., 1996; Pimentel, 1998). 
Em plantas superiores, as CATs representam um importante papel no mecanismo de defesa antioxidante e de transduções de sinais, que responde aos estresses ambientais (Léon et al., 1995).

As CATs parecem ser sensíveis à fotoinativação, especialmente em baixa temperatura, levando a uma severa inibição da fotossíntese (Elstner \& Osswald, 1994). As reações de catalase tornam-se mais importantes quando a concentração de $\mathrm{H}_{2} \mathrm{O}_{2}$ aumenta, pois em concentração normal de $\mathrm{H}_{2} \mathrm{O}_{2}$, este é reduzido pela glutationa e peroxidase (Rice-Evans et al., 1991).

O número de isoenzimas de CAT em vegetais é variável (Havir \& McHale, 1989; Ota et al., 1992). Vitória et al. (2001) observaram aumento da atividade de catalase em raízes e folhas de Raphanus sativus submetidas a doses crescentes de $\mathrm{Cd}$ em sistema hidropônico. Vanacker et al. (1998), estudando a associação entre cevada e o fungo fitopatogênico Blumeria gramminis, observaram o incremento da atividade de catalase em associações compatíveis em relação ao controle não-infectado.

\subsubsection{Superóxido dismutase (E.C.1.15.1.1; SOD)}

Superóxido dismutase é uma enzima de oxidorredutase e pode ligar-se a um composto metálico, denominando-se metaloenzima, sendo encontrada em três diferentes formas, de acordo com o componente metálico associado. Assim existem SODs contendo cobre e zinco ( $\mathrm{Cu} / \mathrm{Zn}$-SOD), manganês (Mn-SOD) ou ferro (Fe-SOD) (Rice-Evans et al., 1991).

As isoenzimas da SOD estão presentes em seres aeróbios, anaeróbios facultativos e alguns anaeróbios obrigatórios (Scandalios, 1990; Rice-Evans et al., 1991). As $\mathrm{Cu} / \mathrm{Zn}$-SODs são geralmente encontradas no citoplasma ou ligadas à membrana dos tilacóides dos cloroplastos de células eucarióticas. As Mn-SODs são encontradas na matriz de mitocôndrios, associadas à membrana nos cloroplastos de algumas plantas (Fridovich, 1986; Bowler et al., 1992; Sehmer \& Dizengremel, 1998) e em procariotos. As Fe-SODs são encontradas em procariotos e em algumas plantas, 
presentes no estroma dos cloroplastos, peroxissomos e mitocôndrios de tecidos não fotossintetizantes (Scandalios, 1993; Becana et al., 1998). A massa molecular dessas isoformas, dependendo da estrutura dimérica ou tetraédrica que apresentam, varia entre 30 e $90 \mathrm{~Kb}$ (Scandalios, 1990).

Esta enzima catalisa a conversão de radicais livres de $\mathrm{O}_{2}{ }^{\bullet-}$ a $\mathrm{H}_{2} \mathrm{O}_{2}$ e $\mathrm{O}_{2}$, segundo a reação:

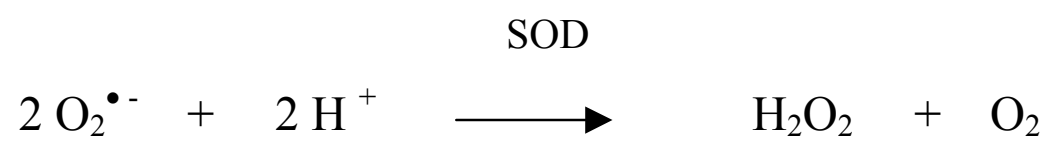

apresentando-se na forma de isoenzimas, as quais têm como função remover o radical superóxido ativo para proteger e levar as plantas a um estado de equilíbrio contra danos celulares causados pelas EAOs (Vallejos, 1983; Rice-Evans et al., 1991; Bowler et al., 1992; Elstner \& Osswald, 1994).

Diferentes estudos têm sido realizados para se compreender a função das SODs no metabolismo de EAOs em plantas, sob diferentes condições, como estresse de metais (Cakmak \& Horst, 1991; Vitória et al., 2001), estresse hídrico (Gogorcena et al., 1995) e outros. Também têm sido utilizadas em pesquisas envolvendo manipulação genética, na tentativa de obtenção de fenótipos tolerantes ao estresse (Bowler et al., 1992). Em todos estes casos foi observada a participação das EAOs nos danos celulares e a indução das SODs como importante mecanismo de proteção das plantas.

Poucos estudos foram relacionados à atividade da enzima em FMAs. Arines et al. (1994), estudando o sistema simbiótico de Pisum sativum e Glomus mosseae, avaliaram os padrões eletroforéticos e atividades de SODs em raízes micorrizadas e não micorrizadas, e os resultados mostraram que isoformas de SOD eram expressas preferencialmente em raízes micorrizadas. Palma et al. (1993) observaram que certas isoenzimas de SOD são induzidas pelo FMA em sistemas de Trifolium pratense com Glomus mosseae. 
A atividade específica de SOD em plantas de alface (Lactuca sativa) colonizadas com G. mosseae e Glomus deserticola e sujeitas a estresse hídrico foi maior em relação aos controles não micorrizados, concluindo-se que a indução de SODs em plantas micorrizadas estaria relacionada aos mecanismos de interação entre FMAs e a planta, em resposta ao estresse hídrico (Ruiz-Lozano et al., 1996).

\subsubsection{Oxidase do ácido-indolacético (AIA-oxidase)}

A oxidase do ácido-indolacético é uma pequena proteína com carga positiva fraca, constituída por um sistema complexo de enzimas: uma oxigenase, a qual é uma flavoproteína foto-ativa, que produz peróxido a partir de um substrato e uma peroxidase, a qual utiliza o $\mathrm{O}_{2}$ do peróxido para oxidar o ácido-indolacético (AIA). É considerada uma enzima de oxirredutase, pois não é degradada na ausência de oxigênio (Hare, 1964; Schneider \& Wightman, 1974). Essas enzimas são importantes na regulação do crescimento celular, pois regulam os níveis de hormônios vegetais como AIA, apresentando uma correlação inversa com a enzima. (Haard \& Marshal, 1976; Alfenas, 1998). Segundo Hare (1964), Burdon \& Marshall (1983) e Hoagland (1990) a oxidase de AIA, juntamente com a peroxidase, pode inibir o crescimento e o florescimento de plantas, através da oxidação do ácido indol-3-acético.

A enzima está presente nas células vegetais (Alfenas, 1998) e só está ativa na presença de oxigênio. Sua distribuição e atividade variam de acordo com a espécie, idade e exposição à luz. As raízes geralmente mostram alta atividade e esta também aumenta com o envelhecimento celular e perda do crescimento da planta (Gortner \& Kent, 1953).

Existem vários fatores que promovem a destruição da oxidase de AIA, como a concentração da enzima e do substrato, a temperatura, a presença de $\mathrm{O}_{2}$, o tempo de reação, pH, luminosidade e a presença de certos cofatores e inibidores (Hare, 1964).

Teoricamente, em locais onde são detectadas atividades de oxidase e peroxidase, considera-se que existe atividade da oxidase de AIA (Benes \& Seidlová, 
1978). A reação da oxidase de AIA ocorre junto à peroxidase e consiste em oxidar em várias etapas o hormônio de crescimento ácido-indolacético (AIA). As duas atividades residem na mesma molécula da enzima e se manifestam no mesmo sentido, ou seja, a maior atividade de peroxidase corresponde à maior atividade de oxidase de AIA (Alfenas, 1998). O efeito enzimático está relacionado com a obrigatoriedade da presença de peroxidase e $\mathrm{Mn}^{2+}$ no extrato, pois junto a fenóis e substratos da peroxidase agem como cofatores na oxidação do AIA (Hare, 1964).

A atividade das duas enzimas geralmente aumenta com a idade da planta e situações de estresse, como presença de ferimentos, invasão de patógenos e exposição ao etileno (Hare, 1964).

Bohnsack \& Albert (1977), em estudos do efeito da deficiência de boro em raízes de abóbora, sobre os níveis de oxidase de AIA, mostraram que o crescimento de raízes foi inibido antes que o aumento da atividade de oxidase de AIA fosse detectado. Plantas com aplicação de AIA e deficiência de B apresentaram aumento na atividade de oxidase de AIA e o crescimento da raiz foi inibido. Concluíram então que altos níveis de AIA podem inibir a divisão celular e conduzir à indução da enzima oxidase de AIA.

Morgan et al. (1976), em estudo com plantas de algodão colocadas em solução nutritiva, com diferentes níveis de $\mathrm{Mn}^{+2}$, observaram que plantas inicialmente deficientes em $\mathrm{Mn}^{+2}$ apresentaram alta atividade da oxidase de AIA e pouco desenvolvimento. Quando trocada a solução para níveis de $\mathrm{Mn}^{+2}$ normais, as plantas recuperaram o crescimento e declinaram na atividade da oxidase de AIA. Em altas concentrações de $\mathrm{Mn}^{+2}$, a planta sofreu severa inibição de crescimento, mas manteve atividade enzimática normal. Portanto não houve indução pelo aumento dos níveis de Mn na planta. 


\subsubsection{Hipóteses}

- As atividades das enzimas catalase, peroxidase, superóxido dismutase e oxidase de AIA aumentam em função da disponibilidade de Mn, mas o aumento da atividade é menor nas plantas micorrizadas.

- As plantas micorrizadas apresentam alterações nos padrões de enzimas catalase, peroxidase, superóxido dismutase e oxidase de AIA em épocas distintas do estabelecimento da simbiose. Espera-se que, nas fases iniciais, as atividades dessas enzimas sejam maiores nas plantas micorrizadas, pois nessa fase, o fungo constitui um dreno de $\mathrm{C}$ da planta e um fator de estresse. Após o estabelecimento da simbiose, esperase que as atividades enzimáticas sejam menores nas plantas micorrizadas, em virtude do seu efeito protetor contra o excesso de Mn.

- A diminuição das atividades enzimáticas em decorrência da alteração da toxidez de Mn nas plantas micorrizadas é um fator intrínseco à presença do FMA e não apenas um efeito do aumento da absorção de $\mathrm{P}$ pelas plantas micorrizadas.

\subsubsection{Objetivos}

- Avaliar as atividades da catalase, peroxidase, oxidase do AIA e superóxido dismutase, as quais, à exceção da oxidase do AIA, são enzimas relacionadas aos estresses oxidativos, os quais podem ser desencadeados durante a toxicidade causada pelo excesso de Mn.

- Relacionar os padrões de atividades enzimáticas com os teores de P, Ca, Fe e Mn na parte aérea e raízes das plantas de soja, na presença e ausência de fungos micorrízicos.

-Verificar, através dos resultados obtidos, se a atenuação da toxidez de Mn é devido a um efeito direto da micorrização ou se indireto, devido ao aumento da absorção de $\mathrm{P}$ pelas plantas micorrizadas. 


\section{MATERIAL E MÉTODOS}

\subsection{Instalação do experimento}

O experimento foi instalado e conduzido em casa de vegetação nas dependências do Departamento de Solos e Nutrição de Plantas da Escola Superior de Agricultura "Luiz de Queiroz", em Piracicaba, Estado de São Paulo, sob condições controladas de temperatura e umidade. Durante o experimento foram utilizadas iluminação natural e lâmpadas incandescentes para aumentar o fotoperíodo (das 5:30 às 8:00 h e das 17:00 às 20:00 h) e a radiação. A temperatura foi controlada por meio de aquecedores e exaustores. Através de termostatos os aparelhos foram acionados quando a temperatura atingia, respectivamente, $18^{\circ} \mathrm{C}$ e $32^{\circ} \mathrm{C}$.

O delineamento experimental utilizado foi inteiramente casualizado, em esquema fatorial, $4 \times 5$, com 5 repetições, sendo 4 os níveis do fator de tratamento com dois isolados de FMA, Glomus etunicatum (Ge) e Glomus macrocarpum (Gm), cada qual com $30 \mathrm{mg} \mathrm{kg}^{-1}$ de $\mathrm{P}$ adicionado ao substrato, e dois controles não inoculados,

sendo um com $30 \mathrm{mg} \mathrm{kg}^{-1}$ de P (CtP1) e outro com $50 \mathrm{mg} \mathrm{kg}^{-1}$ de P (CtP2), 5 níveis de Mn $\left(0,5,10,20,40 \mathrm{mg} \mathrm{kg}^{-1}\right)$. Foram realizadas duas épocas distintas de colheita, a primeira aos 45 dias e a segunda aos 90 dias.

É de grande importância a avaliação de plantas micorrizadas em pelo menos duas épocas distintas de acordo com as duas fases da simbiose, visto que, dependendo do seu estádio de crescimento, as respostas das plantas poderão ser diferenciadas e levar a interpretações equivocadas. 
O substrato utilizado foi o solo classificado como Neossolo Quartzarênico típico, previamente autoclavado por 2 horas a $121^{\circ} \mathrm{C}(1 \mathrm{~atm})$, com o intuito de eliminar FMAs nativos. Amostras do substrato foram retiradas antes e depois da autoclavagem para análise química e em seguida foram feitos os cálculos de calagem e adubação.

Os recipientes experimentais foram vasos de plástico, previamente lavados com solução Lysoform ${ }^{\circledR}$ e enxaguados em água de torneira e água destilada. Os vasos foram preenchidos com $4 \mathrm{~kg}$ de solo devidamente corrigidos e adubados de acordo com o resultado da análise química e adubação recomendada para a cultura da soja de São Paulo (Raij et al., 1985).

Para correção do valor de $\mathrm{pH}$ foi feita calagem com base em uma curva de neutralização, utilizando-se $\mathrm{CaCO}_{3}$, para evitar excessivo aumento do $\mathrm{pH}$ e conseqüente indisponibilidade do $\mathrm{Mn}$. $\mathrm{O}$ valor de $\mathrm{pH}$ utilizado para cálculo foi de 5,2 (valores estáveis de $\mathrm{pH}$ na dose $0,15 \mathrm{~g}$ de $\mathrm{Ca} \mathrm{CO}_{3}$ ), resultando na aplicação de $2,25 \mathrm{~g}$ $\mathrm{CaCO}_{3} /$ vaso.

Como nesse experimento foram empregadas 2 doses de $\mathrm{P}$ nas plantas controles para compensar as diferenças de crescimento entre as plantas micorrizadas e não micorrizadas, aplicaram-se nos vasos com $30 \mathrm{mg} \mathrm{kg}^{-1}, 0,667 \mathrm{~g}$ de $\mathrm{P}$ e nos vasos com $50 \mathrm{mg} \mathrm{kg}{ }^{-1}, 1,11 \mathrm{~g}$ de $\mathrm{P}$, ambos na forma de superfosfato triplo. Também foram aplicados por vasos $1,341 \mathrm{~g}$ de $\mathrm{K}$ na forma de $\mathrm{KNO}_{3}, 1,183 \mathrm{~g}$ de $\mathrm{N}$ na forma de $\mathrm{NH}_{4} \mathrm{NO}_{3}$, considerando o $\mathrm{N}$ aplicado na forma de $\mathrm{KNO}_{3}, 4,612 \mathrm{~g}$ de $\mathrm{Mg}$ na forma de $\mathrm{MgSO}_{4} \cdot 7 \mathrm{H}_{2} \mathrm{O}$, o que também forneceu o $\mathrm{S}$ para a cultura. Antes do plantio, foram fornecidos apenas $44 \%$ da dose de N, $50 \%$ do Mg e o restante em cobertura após 30 dias do transplantio.

Os micronutrientes foram empregados nas seguintes quantidades por vaso: 1,429g de $\mathrm{B}$ na forma de $\mathrm{H}_{3} \mathrm{BO}_{3}, 295 \mathrm{mg}$ de $\mathrm{Cu}$, na forma de $\mathrm{CuSO}_{4} 5 \mathrm{H}_{2} \mathrm{O}, 990$ mg de $\mathrm{ZnSO}_{4} .7 \mathrm{H}_{2} \mathrm{O}$. Estes foram pesados e dissolvidos em $5 \mathrm{~L}$ de água e em seguida foram pipetados $20 \mathrm{~mL}$ da solução na superfície do vaso. $\mathrm{O} \mathrm{Mn}$ foi adicionado na forma de $\mathrm{MnCl}_{2} \cdot 4 \mathrm{H}_{2} \mathrm{O}$ em 4 níveis $\left(5,10,20\right.$ e $\left.40 \mathrm{mg} \mathrm{kg}^{-1}\right)$, resultando respectivamente em $71,96 \mathrm{mg}, 143,92 \mathrm{mg}, 287,85 \mathrm{mg}$ e $575,71 \mathrm{mg}$ do sal. Foram dissolvidas as doses 
necessárias em $1 \mathrm{~L}$ de água destilada e tomaram-se $20 \mathrm{~mL}$ por vaso. O nível zero (dose 0) de Mn não recebeu adição deste sal (considerando-se a presença de $8,2 \mathrm{mg} \mathrm{kg}^{-1}$ de $\mathrm{Mn}$ no substrato utilizado).

A infestação do substrato com FMAs foi feita antes do transplantio. O inóculo de cada espécie foi constituído por uma suspensão de esporos extraídos por peneiramento úmido (Gerdemann \& Nicolson, 1963) seguido de centrifugação em solução de sacarose para aumentar a pureza. O Glomus macrocarpum foi proveniente do solo de um experimento prévio de Nogueira \& Cardoso (2000), o Glomus etunicatum foi extraído de vasos de multiplicação com Brachiaria decumbens. A suspensão de esporos foi ajustada para se obterem 400 esporos em $40 \mathrm{~mL}$ que foram adicionados e incorporados na superfície. Logo após a adição, a superfície do vaso foi revolvida para o recebimento das plântulas de soja, o que permitiu a incorporação superficial dos esporos.

A cultivar de soja utilizada foi IAC 8-2, a qual apresenta sintomas de toxidez de Mn facilmente identificáveis e declínio de crescimento e produção com altos níveis de Mn. As sementes foram desinfestadas com hipoclorito de sódio 25\% de uma solução comercial e colocadas para germinar a $28^{\circ} \mathrm{C}$ em bandeja com areia lavada e autoclavada. Após alguns dias, 5 plântulas foram transplantadas para cada vaso e quando apresentaram folha cotiledonar completamente expandida e início de emissão do primeiro trifólio, foram deixadas as 2 plantas mais viçosas por vaso.

Após 7 dias da completa emergência das plântulas, todos os vasos de todos os tratamentos receberam $20 \mathrm{~mL}$ de um filtrado de suspensão do solo original não autoclavado, numa tentativa de restabelecer a comunidade microbiana original, exceto FMAs. Foram tomados cerca de $3 \mathrm{~kg}$ de solo que foram suspensos em $5 \mathrm{~L}$ de água de torneira. A suspensão resultante foi passada por uma série de peneiras, sendo a menor de $44 \mu \mathrm{m}$. Posteriormente foi feita uma avaliação sob microscópio estereoscópio, para verificar a ausência de esporos de FMAs.

Durante o experimento, as plantas foram regadas com água destilada, conforme a necessidade e mantidas a $80 \%$ da capacidade de retenção de água. 


\section{2 Época de colheita}

Foram realizadas 2 colheitas em épocas diferentes. A $1^{\text {a }}$ colheita foi realizada a 45 dias após o plantio e a $2^{\mathrm{a}}$ colheita a 90 dias após o plantio.

Durante o experimento foram coletadas folhas e raízes para diagnose foliar, avaliação nutricional e enzimática. Para a avaliação enzimática foi retirada a $3^{\mathrm{a}}$ folha trifoliada a partir do ápice e uma parte da raiz.

\subsection{Análises Laboratoriais}

\subsubsection{Massa do material seco da parte aérea (MSPA) e raiz (MSR)}

Em cada época de colheita a parte aérea foi separada da raiz. Depois da retirada do terceiro trifólio a partir do ápice, para análise de atividade enzimática, a parte aérea foi lavada em água destilada, em seguida acondicionada em sacos de papel e levada à estufa com circulação forçada de ar a $70^{\circ} \mathrm{C}$ por 48 horas para obtenção da massa do material seco da parte aérea (MSPA). A raiz foi lavada em água corrente, seca em papel absorvente e pesada para obtenção do peso da matéria fresca, em seguida a amostra foi subdividida em 2 ou 3 partes para análise nutricional, análise enzimática e colonização radicular. $\mathrm{O}$ restante da raiz foi acondicionado em saco de papel e levado à estufa como anteriormente descrito para obtenção da massa do material seco da raiz (MSR).

\subsubsection{Determinação da concentração de nutrientes}

O material seco da parte aérea e raiz foi moído em peneira de 60 mesh, submetido à digestão nítrico-perclórica, preparado segundo Sarruge \& Haag (1974) e 
foram determinadas as concentrações de $\mathrm{Ca}, \mathrm{Mn}$ e $\mathrm{Fe}$ por espectrofotometria de absorção atômica e de P por meio de colorimetria do metavanadato (Malavolta et al., 1989).

\subsubsection{Porcentagem de colonização radicular}

Após a colheita as amostras de raiz foram preservadas em solução de AFA (a 4 L de água destilada, acrescentam-se $500 \mathrm{~mL}$ de formaldeído, $2 \mathrm{~L}$ de álcool etílico e $100 \mathrm{~mL}$ de ácido acético glacial).

A clarificação e coloração das raízes foram feitas através do método descrito por Phillips \& Hayman (1970). As raízes foram descoradas com solução de $\mathrm{KOH}(10 \%)$ em banho Maria a $90^{\circ} \mathrm{C}$ por 45 min, lavadas com água corrente e acidificadas em solução de $\mathrm{HCl}(10 \%)$ por $3 \mathrm{~min}$. Em seguida as raízes foram coradas com solução azul-de-tripano $0,05 \%$ em lactoglicerol por 5 min a $90^{\circ} \mathrm{C}$. A verificação e quantificação da porcentagem de colonização radicular pelos FMAs foi feita por meio da observação destas raízes sob microscópio estereoscópio no aumento de 40 vezes pelo método de Giovanneti \& Mosse (1980). Neste método, utiliza-se uma placa quadriculada contendo as amostras, acompanham-se as linhas horizontais da placa e contam-se as raízes que interceptam essas linhas, verificando se há ou não colonização no ponto de intersecção. A partir do número total, obtém-se a porcentagem de colonização radicular.

\subsubsection{Extração e quantificação do micélio extrarradicular total}

Após a desmontagem dos vasos, cerca de $300 \mathrm{~g}$ do substrato foram retirados e acondicionados em saco plástico devidamente identificado e armazenado em câmera fria a $5^{\circ} \mathrm{C}$ até o momento da extração do micélio extrarradicular. Para isto foi utilizado o método preconizado por Nogueira \& Cardoso (2000). 
Após a extração do micélio extrarradicular foi feita a sua quantificação através do método de fluorescência induzida com diacetato de fluoresceína (FDA) preparado de acordo com Schubert et al. (1987).

\subsubsection{Colheita do material vegetal, estocagem e extração de proteínas}

Para extração de proteínas foi retirado o terceiro trifólio a partir do ápice e uma parte da raiz, que foi estocado a $-80^{\circ} \mathrm{C}$ em nitrogênio líquido. Aproximadamente $0,5 \mathrm{~g}$ dos tecidos foram macerados em nitrogênio liquido e homogeneizados em $1 \mathrm{~mL}$ de solução de extração contendo $34 \mathrm{mM}$ de $\mathrm{K}_{2} \mathrm{HPO}_{4} ; 0,2 \mathrm{M}$ de sacarose; PVP-40 2,56 \%; 3 $\mathrm{mM}$ de DTT; 5,7 mM de L-ácido ascórbico; 5,8 mM de DIECA; 2,6 mM de $\mathrm{NaHSO}_{4}$. $\mathrm{H}_{2} \mathrm{O} ; 2,5 \mathrm{mM}$ de $\mathrm{Na}_{2} \mathrm{~B}_{4} \mathrm{O}_{7} .10 \quad \mathrm{H}_{2} \mathrm{O}$ (borato de sódio); $\beta$-mercaptoetanol 0,2\%; polietilenoglicol 1\% e água deionizada (Alfenas et al., 1991). O homogeneizado obtido foi centrifugado a $3.000 \mathrm{~g}$ por 30 minutos a $4^{\circ} \mathrm{C}$ em uma centrífuga Jouan modelo Br4i. O sobrenadante foi coletado, dividido em alíquotas e congelado a $-20^{\circ} \mathrm{C}$, para posterior ensaio de atividades enzimáticas.

Um dos maiores problemas encontrados na extração de proteínas e enzimas de plantas é a presença de compostos fenólicos liberados durante a trituração do tecido. Tais fenóis, quando descompartimentalizados, são prontamente oxidados a quinonas por enzimas da própria planta (polifenoloxidases e peroxidases). Tanto os compostos fenólicos não oxidados quanto as quinonas reagem com as proteínas e inativam enzimas. Para eliminar este problema foram utilizados métodos de extração específicos (Alfenas et al., 1991). 


\subsubsection{Determinação de proteínas}

A concentração de proteína total solúvel foi determinada conforme Bradford (1976), utilizando-se albumina de soro bovino (BSA) como padrão. Fez-se a leitura de absorbância a $595 \mathrm{~nm}$ em espectrofotômetro de microplacas BioRadMicroplate modelo Reader Benchmark. A concentração de proteínas foi expressa em $\mu \mathrm{g}$ de BSA por $\mathrm{mL}$ de extrato ( $\mu \mathrm{g}$ proteína $\mathrm{mL}^{-1}$ ) e determinada através do programa Microplate Manager 5.1 - BioRad.

\subsubsection{Atividade Enzimática}

A atividade enzimática da folha e raiz foi avaliada pelo método PAGE não-denaturante e analisada visualmente. Os extratos foram aplicados em géis de poliacrilamida a $10 \%$ e gel de empilhamento a $4 \%$. O tampão de corrida utilizado foi

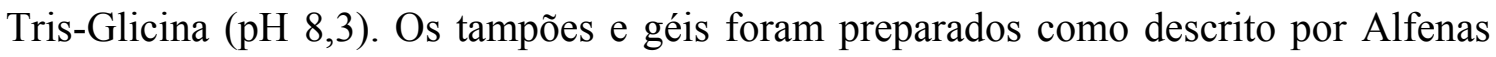
(1998).

\subsubsection{Catalase (EC 1.11.1.6; CAT)}

A eletroforese foi conduzida a $4^{\circ} \mathrm{C}$ em corrente constante de $25 \mathrm{~mA} / \mathrm{placa}$ em tempo médio de corrida de $12 \mathrm{~h}$. Foram aplicadas nos géis amostras padrão de CAT de fígado de boi e $44 \mu \mathrm{g} \mathrm{mL}^{-1}$ de proteína total solúvel dos extratos de folha e raiz. Revelaram-se os géis pelo método de Woodbury et al. (1971). O gel foi lavado com água deionizada por $45 \mathrm{~min}$ (com troca a cada $15 \mathrm{~min}$ ) sob agitação e imerso em $\mathrm{H}_{2} \mathrm{O}_{2}$ 0,003\% (v/v) por $10 \mathrm{~min}$. Em seguida, o gel foi lavado rapidamente com água deionizada e tratado com uma solução de $\mathrm{FeCl}_{3} 1 \%(\mathrm{~m} / \mathrm{v})$ e $\mathrm{K}_{3} \mathrm{Fe}(\mathrm{CN})_{6} 1 \%(\mathrm{~m} / \mathrm{v})$ por 10 
min à temperatura ambiente. Após coloração, o gel foi lavado com água deionizada, fixado em ácido acético $7 \%$ e fotografado.

\subsubsection{Oxidase de ácido indolacético (AIA-oxidase)}

A eletroforese foi conduzida a $4^{\circ} \mathrm{C}$ em corrente constante de $25 \mathrm{~mA} /$ placa em tempo médio de corrida de $2 \mathrm{~h}$. Foram aplicados nos géis $120 \mu \mathrm{g} \mathrm{mL} \mathrm{m}^{-1}$ de proteína total solúvel do extrato de folha e raiz. Revelaram-se os géis pelo método de Gordon \& Weber (1951). Colocou-se o gel em solução contendo o sal Fast Blue BB (FBBB) 4 mg $\mathrm{mL}^{-1}$ em etanol, $50 \mathrm{~mL}$ de água destilada contendo $2 \mu \mathrm{M}$ de ácido p-cumárico em etanol, $2 \mu \mathrm{M}$ de $\mathrm{H}_{2} \mathrm{O}_{2}$ e $2 \mu \mathrm{M}$ de AIA em etanol e tampão fosfato de sódio $2 \mathrm{M}, \mathrm{pH} 4,2$. Incubou-se o gel à temperatura de laboratório durante 6 horas. Após coloração, o gel foi lavado com água deionizada, fixado em glicerol $10 \%$, fotografado e posteriormente secado em papel celofane.

\subsubsection{Peroxidase (EC 1.11.1.7; PO)}

A eletroforese foi conduzida a $4^{\circ} \mathrm{C}$ em corrente constante de $25 \mathrm{~mA} /$ placa em tempo médio de corrida de $2 \mathrm{~h}$. Foram aplicados nos géis $150 \mu \mathrm{g} \mathrm{mL} \mathrm{L}^{-1}$ de proteína total solúvel do extrato de folha e raiz. Revelaram-se os géis pelo método de Ridge \& Osborne (1970). Colocou-se o gel em solução contendo tampão fosfato pH 6,0 e guaiacol $0,05 \mathrm{M}$ durante 10 min e em seguida, $\mathrm{H}_{2} \mathrm{O}_{2}$ 0,1\%. Após coloração, o gel foi lavado com água deionizada, fixado em glicerol $10 \%$, fotografado e posteriormente secado em papel celofane. 


\subsubsection{Superóxido dismutase (EC 1.15.1.1, SOD)}

A eletroforese foi conduzida a $4^{\circ} \mathrm{C}$ em corrente constante de $25 \mathrm{~mA} /$ placa

em tempo médio de corrida de $2 \mathrm{~h}$. Foram aplicados nos géis $100 \mu \mathrm{g} \mathrm{mL}^{-1}$ de proteína total solúvel do extrato de folha e raiz. Revelaram-se os géis pelo método de Beauchamp \& Fridovich, (1971). Colocou-se o gel em solução contendo riboflavina $0,004 \%$ (p/v), $\mathrm{Na}_{2}$ EDTA 0,3\% (p/v) e NBT 2\% (v/v) em Tris-HCl 0,05M, pH 8,5, permanecendo incubado a $30-37^{\circ} \mathrm{C}$ durante $30 \mathrm{~min}$., exposto a luz. Após coloração, o gel foi lavado com água deionizada, fixado com ácido acético 7\% para paralisar a reação, armazenado em glicerol $10 \%$, fotografado e posteriormente secado em papel celofane.

\subsection{Análise estatística}

O resultados obtidos da matéria seca da parte aérea e raízes, concentração de nutrientes, colonização micorrízica e micélio externo total foram submetidos à análise de variância com aplicação de teste $\mathrm{F}$ através do programa SANEST, ao nível de $5 \%$ de significância. A interação entre os fatores, quando significativos pelo teste $\mathrm{F}$, foi desdobrada. Para os fatores qualitativos (FMAs) foi aplicado o teste de Tukey e os valores quantitativos (doses de $\mathrm{Mn}$ ) foram submetidos à análise de regressão múltipla, ambos ao nível de $5 \%$ de significância. 


\section{RESULTADOS E DISCUSSÃO}

Os resultados de massa do material seco da parte aérea e raiz, da colonização radicular, do comprimento do micélio externo e dos nutrientes serão apresentados resumidamente para auxiliar nas análises enzimáticas.

O principal objetivo dessa dissertação foi a análise da atividade de algumas enzimas antioxidantes. Entretanto, para a avaliação dessa atividade e sua interpretação, torna-se necessário o acompanhamento do crescimento das plantas submetidas aos diferentes tratamentos, bem como a absorção de nutrientes e o desenvolvimento dos sintomas de toxidez de manganês nas plantas de soja.

\subsection{Sintomas de toxicidade de Mn}

Dez dias após o plantio foram notados os primeiros sintomas de toxidez de Mn nas plantas dos tratamentos 20 e $40 \mathrm{mg} \mathrm{kg}^{-1}$ de $\mathrm{Mn}$. As folhas estavam encarquilhadas e apresentavam pontos necróticos no limbo foliar e nervuras (Fig. 1). 


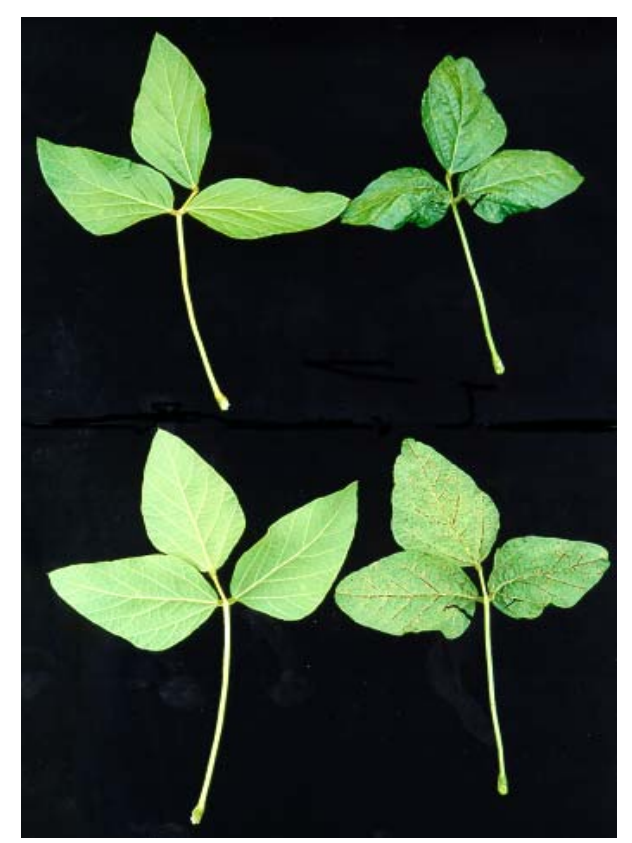

Figura 1 - Aspecto da face adaxial e abaxial de trifólios de soja sadios (da esquerda) e lesionados (da direita) com sintomas de toxidez de Mn dez dias após o plantio.

$\mathrm{Na} 1^{\mathrm{a}}$ colheita (45 dias), observou-se que a severidade da toxidez de $\mathrm{Mn}$ aumentou com as doses de Mn adicionadas, principalmente nas plantas micorrizadas, o que resultou em seu menor crescimento (Fig. 2).

Observou-se que, na $2^{\mathrm{a}}$ colheita (90 dias) nas plantas do CtP1, os sintomas de toxidez de Mn se manifestaram a partir da dose $10 \mathrm{mg} \mathrm{kg}^{-1}$; nas do CtP2, a partir de $20 \mathrm{mg} \mathrm{kg}^{-1}$ de $\mathrm{Mn}$, enquanto que nas micorrizadas somente ocorreram sintomas na dose $40 \mathrm{mg} \mathrm{kg}^{-1} \mathrm{de} \mathrm{Mn}$, porém com menor severidade. Plantas micorrizadas pelo FMA Glomus macrocarpum (Gm), na dose $40 \mathrm{mg} \mathrm{kg}^{-1} \mathrm{de} \mathrm{Mn}$ apresentaram sintomas com menor severidade se comparados àquelas com Glomus etunicatum $(\mathrm{Ge})$ (Fig. 3). 


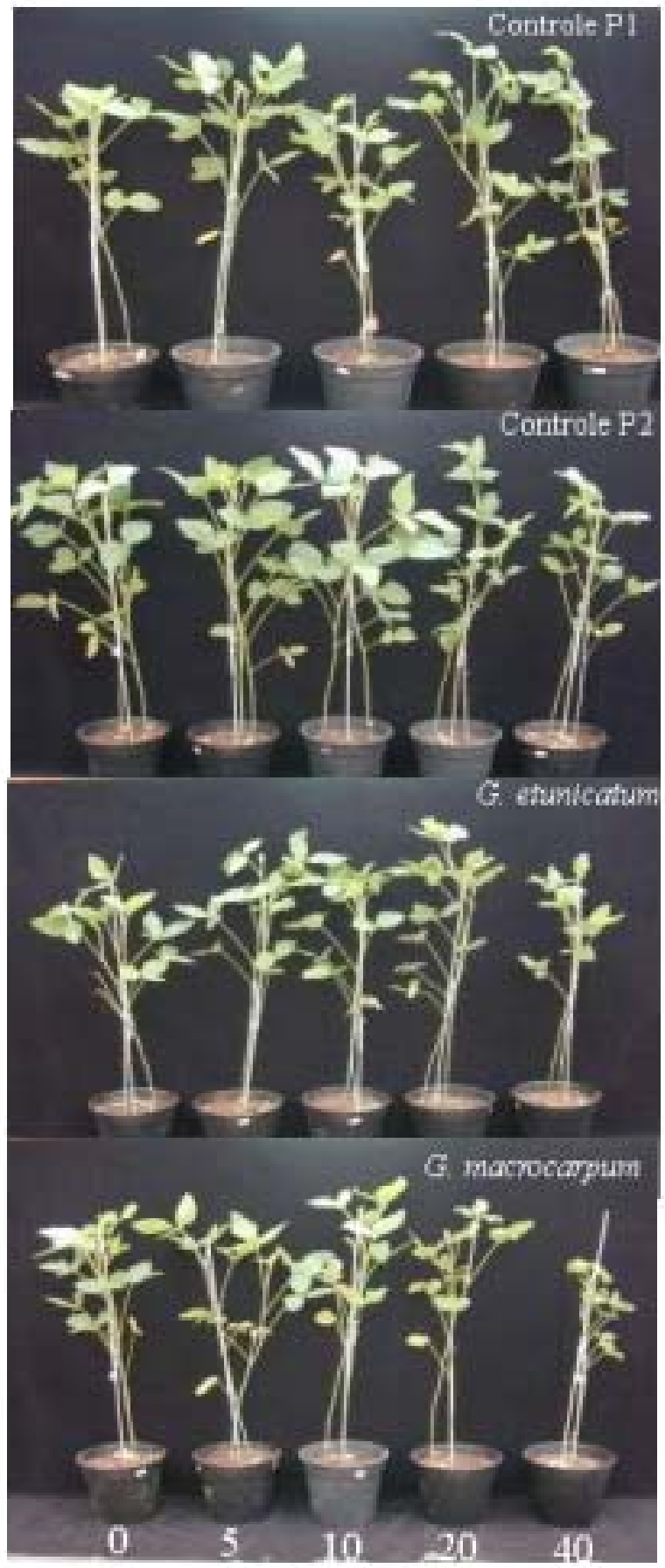

Figura 2 - Aspecto da manifestação dos sintomas de toxidez de Mn em plantas de soja aos 45 dias ( $1^{\text {a }}$ colheita), de acordo com os tratamentos de micorrização e não micorrização nas cinco doses de $\mathrm{Mn}$ adicionadas ao substrato $\left(\mathrm{mg} \mathrm{kg}^{-1}\right)$. 


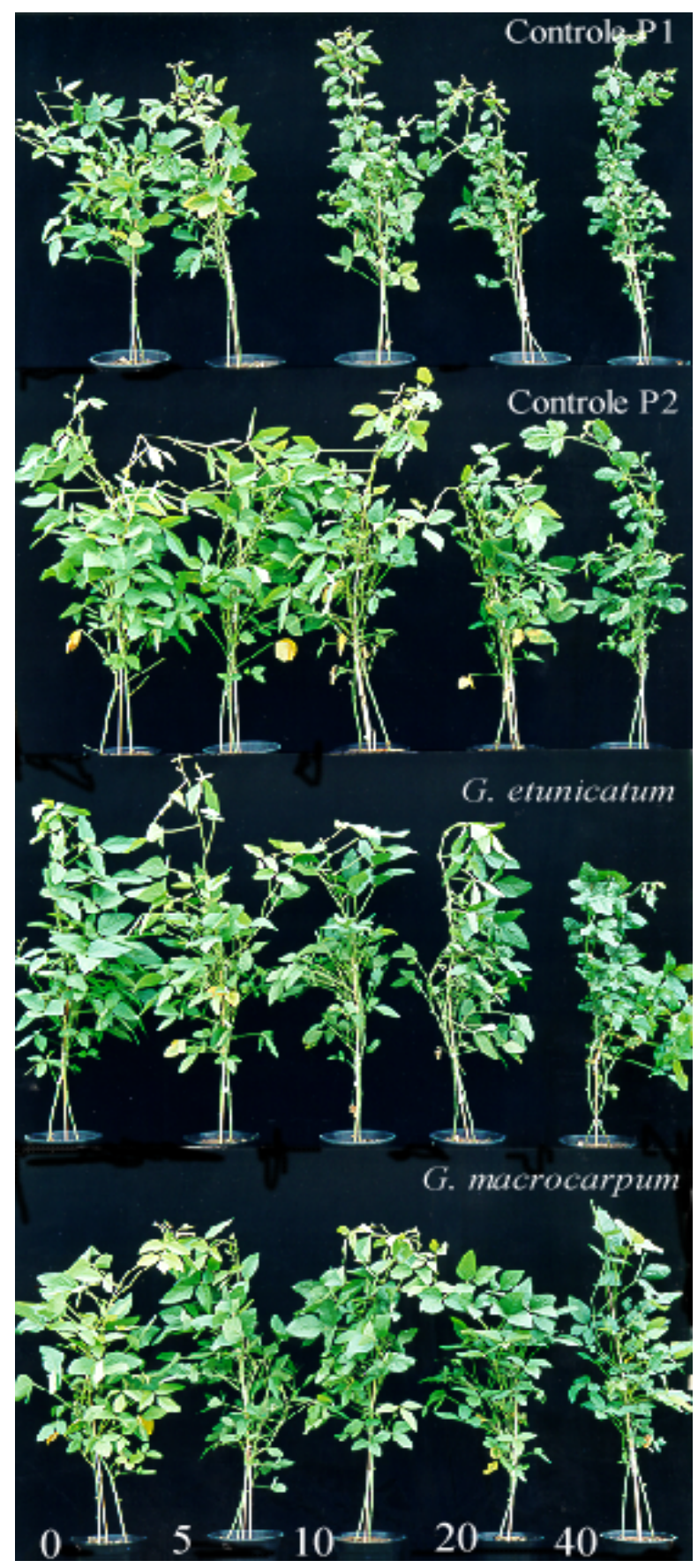

Figura 3 - Aspecto da manifestação dos sintomas de toxidez de Mn em plantas de soja aos 90 dias ( $2^{\text {a }}$ colheita), de acordo com os tratamentos de micorrização e não micorrização nas cinco doses de $\mathrm{Mn}$ adicionadas ao substrato $\left(\mathrm{mg} \mathrm{kg}^{-1}\right)$. 


\subsection{Massa do material seco da parte aérea e raiz}

As massas de material seco da parte aérea (MSPA) e da raiz (MSR) apresentaram a mesma tendência, podendo se utilizar os valores da massa de material seco total (MST).

A produção de matéria seca foi superior na $2^{\mathrm{a}}$ colheita se comparada à produção da $1^{\mathrm{a}}$ colheita em todos os tratamentos, inclusive nos tratamentos com FMAs (Fig. 4), fato explicado pelo desenvolvimento normal do ciclo de vida da planta.

$\mathrm{Na} 1^{\mathrm{a}}$ colheita, as plantas com FMAs, em todas as doses de $\mathrm{Mn}$, apresentaram menor produção de matéria seca, comparando com o tratamento CtP2 (Fig. 4). Este por sua vez, destacou-se dos demais, com maior produção de matéria seca, principalmente na parte aérea. Plantas supridas com maior dose de $\mathrm{P}$, sem atingir nível tóxico, absorvem maior quantidade desse nutriente e conseqüentemente apresentam maior desenvolvimento vegetal (Cardoso, 1996a).

$\mathrm{Na} 2^{\mathrm{a}}$ colheita, plantas do CtP1 destacaram-se por apresentar menor produção de matéria seca (Fig. 4). Neste tratamento foi aplicada dose de P inferior (30 mg. $\mathrm{kg}^{-1}$ ) e, como neste período a planta está no ciclo de vida reprodutivo, apresenta maiores exigências nutricionais com conseqüente falta de $\mathrm{P}$, sendo que essas plantas se desenvolveram menos. O tratamento CtP2 não apresentou diferença na produção de matéria seca em comparação aos tratamentos com FMAs no intervalo entre 10 e $20 \mathrm{mg}$ $\mathrm{kg}^{-1}$ de Mn (Fig. 5). Entretanto, as plantas micorrizadas conseguiram evitar sintomas de toxidez de Mn em todas as doses de Mn menores que $40 \mathrm{mg} \mathrm{kg}^{-1} \mathrm{de} \mathrm{Mn}$, enquanto o CtP2 já os apresentava com $20 \mathrm{mg} \mathrm{kg}^{-1}$ de $\mathrm{Mn}$.

Observando-se os tratamentos com FMAs (Ge e Gm) na $1^{\mathrm{a}}$ e $2^{\mathrm{a}}$ colheita (Fig. 4), nota-se que ocorreu uma inversão de similaridade com relação aos controles. $\mathrm{Na} 1^{\mathrm{a}}$ colheita a tendência da massa de material seco total foi similar a do CtP1 e na $2^{\mathrm{a}}$ colheita a tendência foi similar a do CtP2. O resultado confirma a importância de um experimento com plantas controles e micorrizadas, apresentando diferentes doses de $\mathrm{P}$ para poderem ser comparadas as diferenças fisiológicas. Portanto, o CtP2, que recebeu

maior dose de $\mathrm{P}$ aplicada (50 $\mathrm{mg} \mathrm{kg}^{-1}$ ), pode ser considerado um controle absoluto para 
comparações com as plantas micorrizadas e com desenvolvimento equivalente, pelo menos no final do ciclo vegetal.

Em geral, as plantas com FMAs (Ge e Gm) não apresentaram diferenças significativas entre si, quanto à sua eficiência na produção de matéria seca (Fig 5) e conseqüente promoção do crescimento da planta.

Analisando-se o comportamento das plantas em função das doses de $\mathrm{Mn}$, todas as plantas diminuíram a produção de matéria seca de acordo com o aumento das doses de Mn (Fig. 4), principalmente a partir da dose $20 \mathrm{mg} \mathrm{kg}^{-1}$ de $\mathrm{Mn}$.

Comparando a produção de MST das plantas em todos os tratamentos, na $2^{\mathrm{a}}$ colheita, observou-se, que em geral, o CtP2 e as plantas com FMAs tiveram maior crescimento que o CtP1. Nas doses de 5, 10 e $20 \mathrm{mg} \mathrm{kg}^{-1}$ de $\mathrm{Mn}$ não houve diferenças entre as plantas micorrizadas e o CtP2, mas na dose de $40 \mathrm{mg} \mathrm{kg}^{-1}$ de $\mathrm{Mn}$ o CtP2 sobrepujou o crescimento das plantas com FMAs, o que poderia significar menor efeito tóxico de Mn neste tratamento. Entretanto, apesar disso, os sintomas visuais de toxidez de $\mathrm{Mn}$ nas folhas foram sempre mais atenuados nas plantas micorrizadas do que naquelas do CtP2 (Fig. 3). 

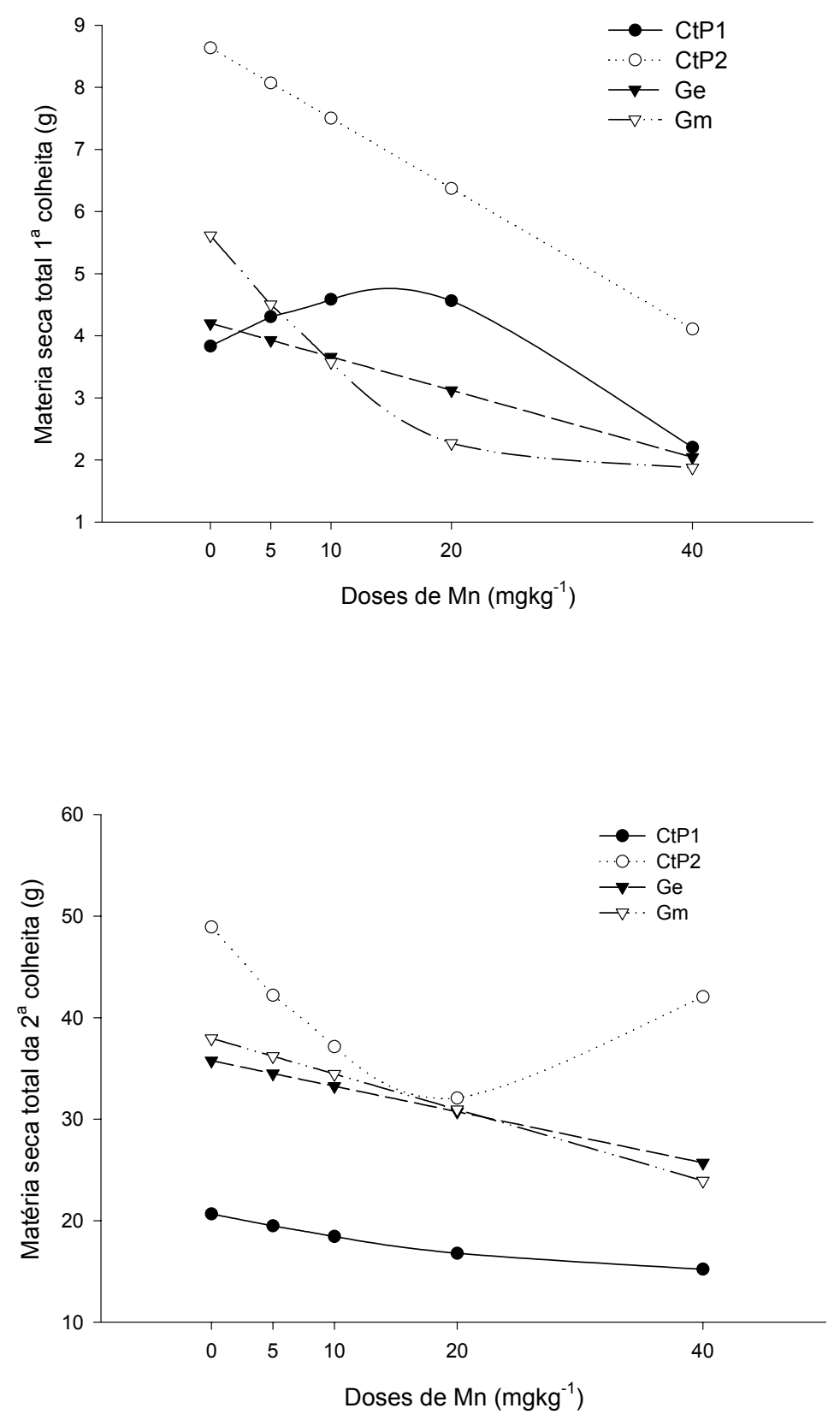

Figura 4 - Análise de regressão polinomial para matéria seca total (MST) de plantas de soja inoculadas ou não com FMAs e submetidas a doses crescentes de Mn, respectivamente aos 45 e 90 dias. 


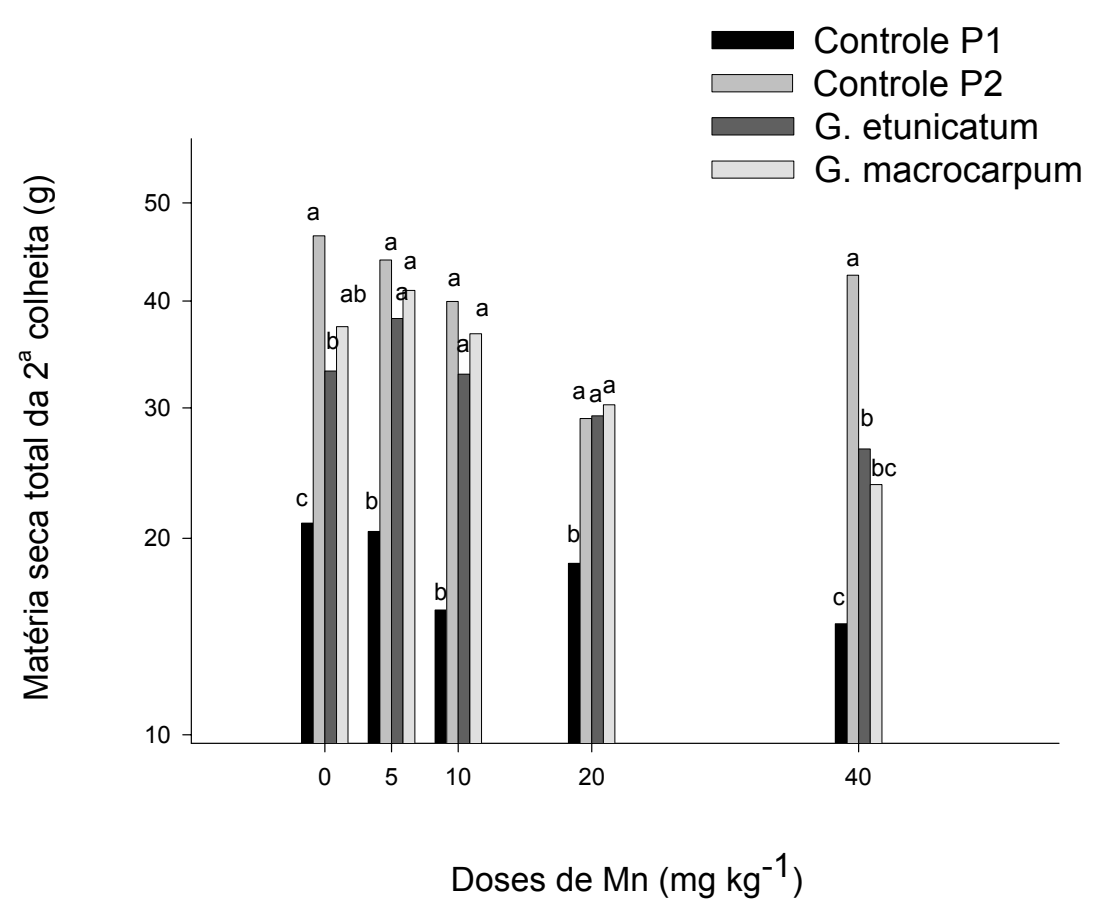

Figura 5 - Matéria seca total de plantas de soja inoculadas ou não com FMAs e submetidas a doses crescentes de Mn aos 90 dias. Letras diferentes indicam diferenças significativas pelo teste de Tukey $(5 \%)$.

\subsection{Colonização Radicular}

A taxa de colonização até a $2^{\mathrm{a}}$ colheita (90 dias) atingiu o valor máximo de 47\%. Minhoni et al. (1993), estudando inoculação com um dos mesmos fungos, $G$. macrocarpum, em soja, obtiveram no final do ciclo da cultura cerca de 35 e $45 \%$ de colonização do sistema radicular, que são equivalentes aos resultados aqui obtidos.

Raízes de plantas não micorrizadas (controles) também foram examinadas e não se observou nenhum sinal de colonização micorrízica, portanto a autoclavagem foi eficiente e não houve contaminação com FMA.

Os resultados obtidos das duas épocas de colheita mostram que existe diferença estatística significativa entre os tratamentos Ge e Gm (Fig. 6), e que o tratamento Gm apresentou maior valor de colonização. Talvez esta seja a razão para a 
atenuação máxima dos sintomas de toxidez de Mn neste tratamento. Apesar disso, nem sempre a eficiência de um endófito é maior por apresentar maior taxa de colonização radicular.

$\mathrm{Na} 1^{\mathrm{a}}$ colheita, a colonização radicular diminuiu com o aumento das doses de Mn (Fig. 7). Neste período, a colonização na dose $0 \mathrm{mg} \mathrm{kg}^{-1}$ de $\mathrm{Mn}$, obteve valor máximo de $29 \%$ e valor mínimo de $3,9 \%$, na dose $20 \mathrm{mg} \mathrm{kg}^{-1}$ de $\mathrm{Mn}$. Portanto houve um grande atraso da colonização devido ao aumento do nível de Mn. Este fato pode explicar a razão do pouco crescimento e da severidade dos sintomas de toxidez de Mn em plantas inoculadas com FMA na $1^{\mathrm{a}}$ colheita (Fig. 2 e 4). Só após este período é que de fato ocorreu a formação efetiva da micorriza nessas plantas (Fig. 7, $2^{\text {a }}$ colheita), fazendo com que obtivessem mais $\mathrm{P}$, acelerassem seu crescimento e conseguissem contra atuar ao efeito da grande disponibilidade de Mn no substrato, o que foi verificado na $2^{\mathrm{a}}$ colheita, aos 90 dias.

A colonização radicular foi maior na $2^{\mathrm{a}}$ colheita e observou-se que só a partir da dose $20 \mathrm{mg} \mathrm{kg}^{-1}$ de $\mathrm{Mn}$ a porcentagem de colonização mostrou tendência a diminuir (Fig. 7). Portanto, os FMAs colonizaram as plantas de forma eficiente, suportando níveis altos de Mn.

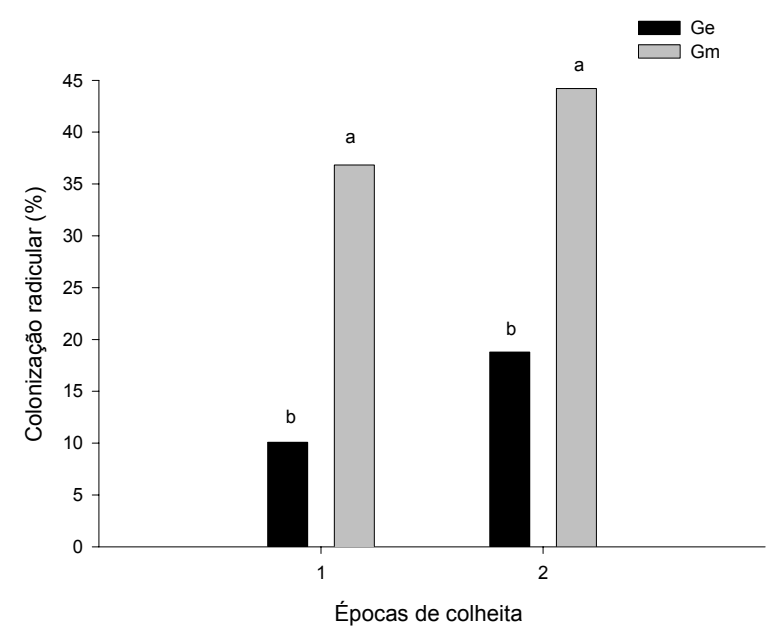

Figura 6 - Colonização radicular de plantas de soja inoculadas com FMAs e submetidas a doses crescentes de $\mathrm{Mn}$ aos 45 e 90 dias. Letras diferentes indicam diferenças significativas pelo teste de Tukey $(5 \%)$. 


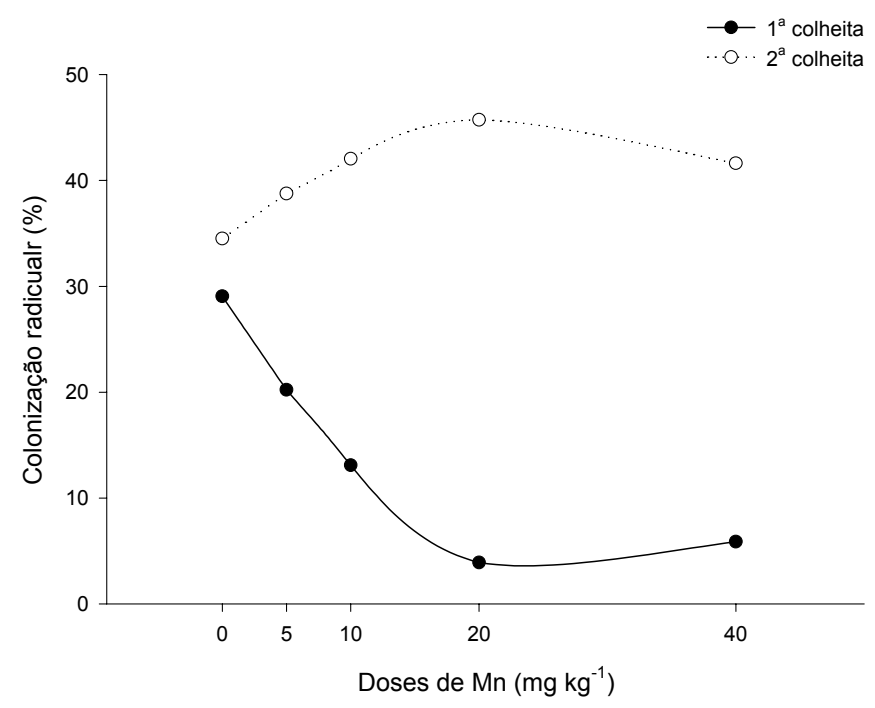

Figura 7 - Análise de regressão polinomial para colonização radicular de plantas de soja inoculadas com FMAs e submetidas a doses crescentes de Mn aos 45 dias e 90 dias.

\subsection{Comprimento do micélio extrarradicular total (MET)}

Existiu diferença significativa entre os tratamentos com FMAs e os tratamentos controles (Fig. 8). Os tratamentos com FMAS apresentaram os maiores valores de MET e não apresentaram diferenças significativas entre eles (Fig. 8).

No método de determinação do comprimento do micélio extrarradicular total (MET) é avaliado o comprimento de hifas vivas de fungos. Obviamente nos tratamentos controles (sem inoculação de FMA) não havia presença de fungo micorrízico (o que também foi confirmado através da taxa de colonização radicular), mas de outros fungos do solo. Por este motivo, alguns pesquisadores preconizam fazerse uma subtração do valor obtido para MET no tratamento controle, do valor obtido pela planta micorrizada. Para isto, é preciso partir-se da hipótese que os fungos não micorrízicos do solo apresentariam a mesma abundância em rizosfera de plantas 
micorrizadas e não micorrizadas. Este ponto, entretanto, é também duvidoso e preferiuse, no presente experimento, simplesmente apresentar os valores médios levantados.

Com relação à regressão polinomial para os níveis de $\mathrm{Mn}$ da $1^{\mathrm{a}}$ colheita, o comprimento do micélio extrarradicular diminuiu de acordo com o aumento das doses de Mn (Fig. 9). Portanto, o aumento da dose de Mn também apresenta um efeito de diminuição no comprimento do micélio extrarradicular dos fungos, ou ainda, havia muito menor taxa de colonização radicular em plantas submetidas a maiores níveis de Mn e, em conseqüência disso, menor formação de micélio extrarradicular.

Os resultados de MET na $2^{\mathrm{a}}$ colheita não foram analisados, pois faltou material para realização da análise.

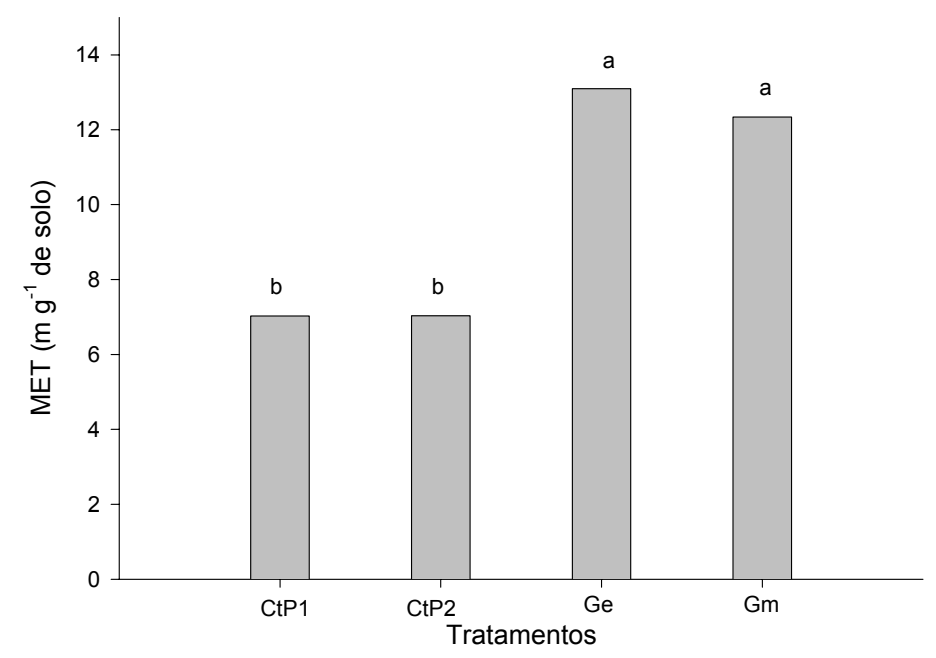

Figura 8 - Comprimento de micélio extrarradicular total (MET) de plantas de soja inoculadas ou não com FMAs e submetidas a doses crescentes de Mn aos 45 dias. Letras diferentes indicam diferenças significativas pelo teste de Tukey $(5 \%)$. 


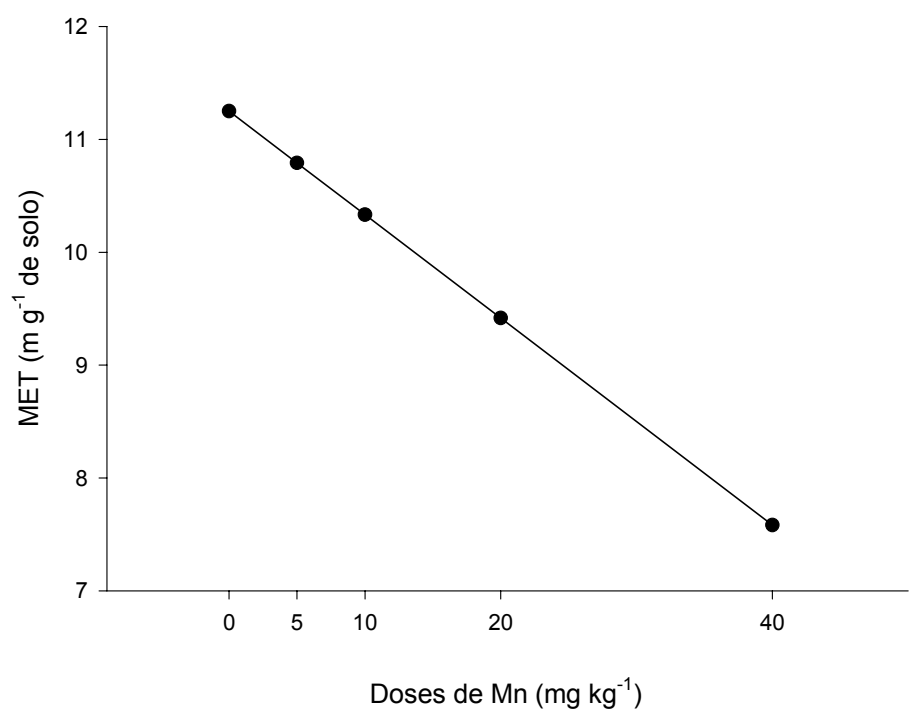

Figura 9 - Análise de regressão polinomial para o comprimento de micélio extrarradicular total (MET) de plantas de soja inoculadas ou não com FMAs e submetidas a doses crescentes de Mn aos 45 dias.

\subsection{Análise dos nutrientes}

\subsubsection{Fósforo na parte aérea e raiz}

$\mathrm{Na} 1^{\mathrm{a}}$ colheita, as plantas do tratamento $\mathrm{Gm}$ apresentaram maior concentração de $\mathrm{P}$ e as demais não diferiram entre si (dados não apresentados). $\mathrm{Na} 2^{\mathrm{a}}$ colheita as plantas com FMAs apresentaram maior concentração de $\mathrm{P}$ na parte aérea (Fig. 10). O tratamento $\mathrm{CtP} 2$ apresentou menor concentração de $\mathrm{P}$ com relação às plantas micorrizadas e também em relação ao CtP1. Esta última diferença pode ser por causa do efeito diluição, pois as plantas CtP2 tiveram crescimento muito superior ao CtP1 (Fig. 4). Visto que as plantas com FMAs apresentaram também maiores valores do comprimento do micélio extrarradicular total (MET) (Fig. 8), pode-se inferir que, 
através desse micélio externo, absorveram maior quantidade de $\mathrm{P}$, mesmo quando este estava presente em quantidade menor na solução do solo, o que levou ao aumento da produção de material seco total.

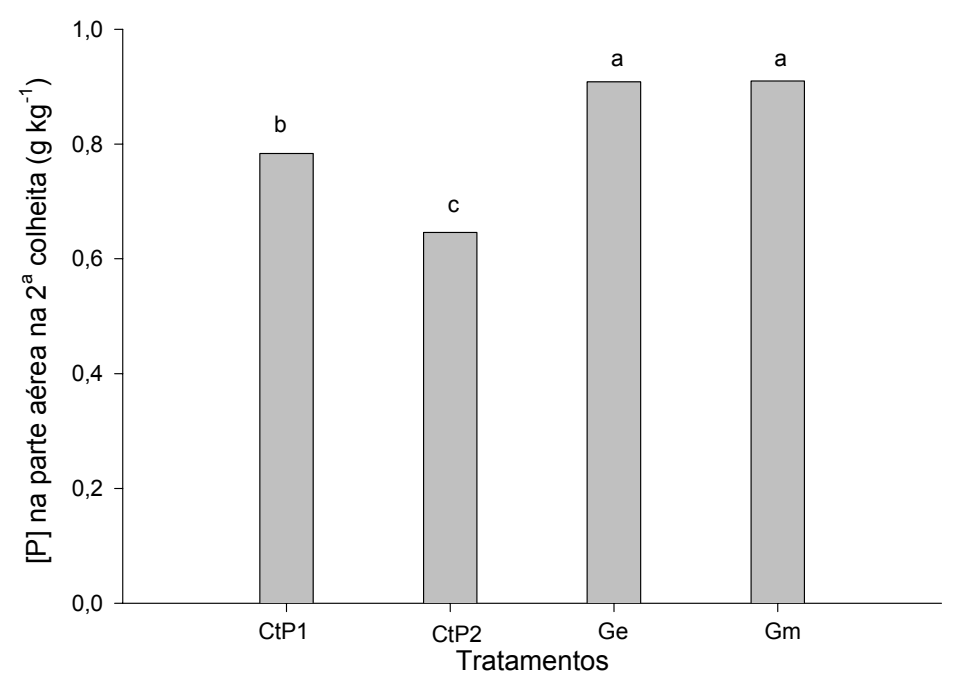

Figura 10 - Concentração de P na parte aérea de plantas de soja inoculadas ou não com FMAs e submetidas a doses crescentes de Mn aos 90 dias. Letras diferentes indicam diferenças significativas pelo teste de Tukey (5\%).

Quanto à regressão polinomial, a tendência das curvas na $1^{\mathrm{a}}$ e $2^{\mathrm{a}}$ colheita mostrou que, com o aumento das doses de Mn, ocorre o aumento da concentração de $\mathrm{P}$ na parte aérea (Fig. 11). Ou seja, o aumento do nível de Mn resultou em menor crescimento e, portanto, menor diluição do $\mathrm{P}$ absorvido.

Observou-se que a concentração de $\mathrm{P}$ diminuiu da $1^{\mathrm{a}}$ colheita para a $2^{\mathrm{a}}$ colheita. Este é resultado do efeito diluição que ocorreu nas plantas micorrizadas que tiveram maior crescimento (Fig. 4). Apesar de parecer que a quantidade de P absorvida 
foi menor nas plantas micorrizadas do que nas plantas controles, pois diminuiu a concentração de $\mathrm{P}$, as plantas micorrizadas absorveram maior quantidade total de $\mathrm{P}$.

A concentração de $\mathrm{P}$ na raiz das plantas, na $1^{\mathrm{a}}$ e $2^{\mathrm{a}}$ colheita, apresentou a mesma tendência daquela que ocorreu na parte aérea (dados não apresentados).

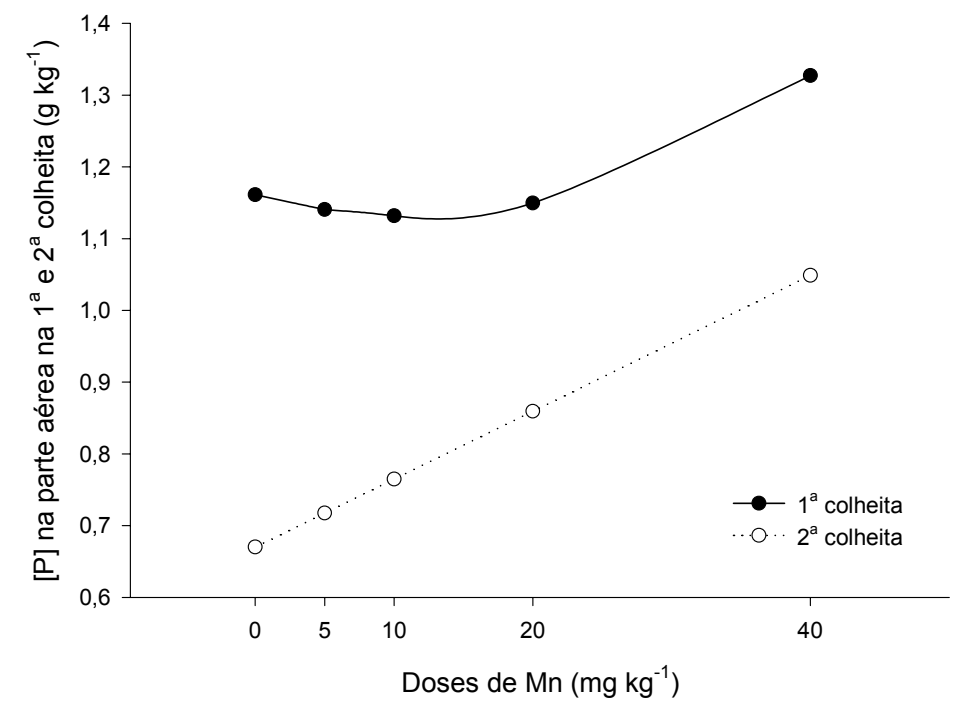

Figura 11 - Análise de regressão polinomial para a concentração de P na parte aérea de plantas de soja inoculadas ou não com FMAs e submetidas a doses crescentes de Mn aos 45 e 90 dias.

\subsubsection{Cálcio na parte aérea e raiz}

$\mathrm{Na}$ análise de regressão polinomial da $1^{\mathrm{a}}$ colheita, observou-se que $\mathrm{o}$ tratamento CtP2 apresentou maior concentração de Ca e os tratamentos com FMAs (Ge e Gm) e o CtP1 menor concentração (dados não apresentados). Na $2^{\mathrm{a}}$ colheita, com relação às doses de Mn, as plantas micorrizadas e aquelas do CtP2 tiveram aumento da concentração de Ca concomitantemente com o aumento das doses de Mn (Fig. 12), de maneira similar ao que ocorreu com o P (Fig. 11). Já o CtP1 manteve concentração mais 
ou menos constante e mais elevada do que nos outros tratamentos até a dose de $20 \mathrm{mg}$ $\mathrm{kg}^{-1}$ de $\mathrm{Mn}$.

É possível que o Ca contra-atue a toxidez de Mn na planta. Segundo Foy (1984), o Mn interage com muitos outros minerais na nutrição da planta e sob certas condições a adição de elementos como Si, Fe, Ca e P alivia a toxicidade de Mn. Mengel et al. (1987) relataram que a toxidez de Mn está freqüentemente associada a baixos teores de Ca e Fe nos tecidos vegetais. Horst \& Marschner (1978) apud Foy (1984) observaram que o excesso de Mn inibiu o transporte de Ca em folhas de feijão, portanto a toxicidade de Mn estaria associada ao decréscimo da concentração de Ca nas plantas. E segundo Masui et al. (1976) apud Foy (1984), a adição de Ca diminui a concentração de Mn.

Os resultados para a concentração de $\mathrm{Ca}$ em plantas micorrizadas deste trabalho em discussão contradizem os resultados obtidos pelos autores acima. $\mathrm{O}$ aumento da concentração de Ca nas plantas micorrizadas de acordo com o aumento das doses de Mn (Fig. 12) sugere que estas aumentam o padrão de absorção de Ca quando submetidas a níveis altos de $\mathrm{Mn}$.

A concentração de Ca na raiz aumentou da $1^{\mathrm{a}}$ para a $2^{\mathrm{a}}$ colheita (dados não apresentados). Com relação ao efeito das doses de $\mathrm{Mn}$, a concentração de Ca na raiz apresentou resultados semelhantes aos da parte aérea. 


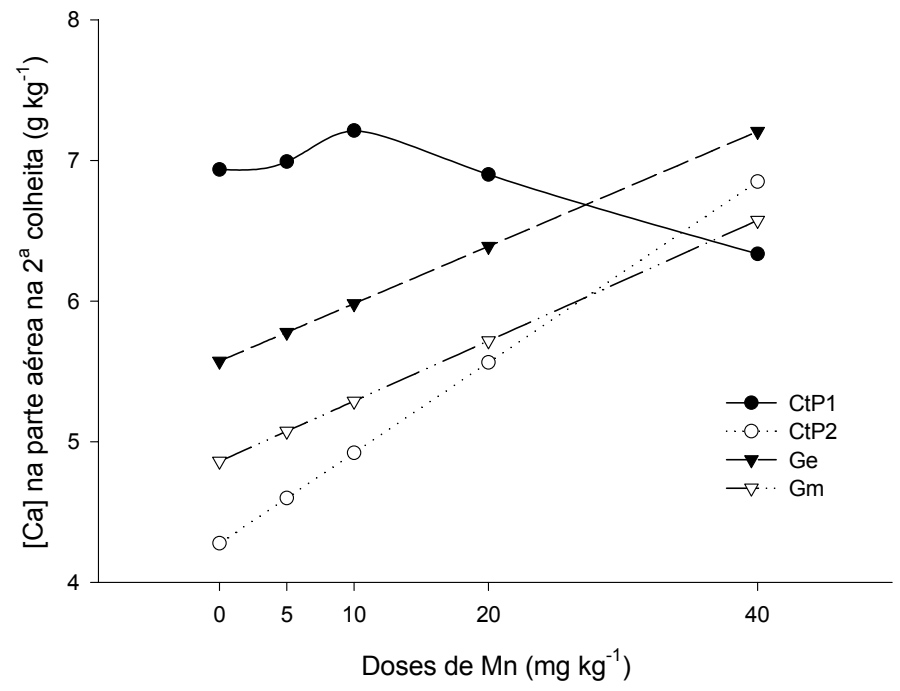

Figura 12 - Análise de regressão polinomial para a concentração de Ca na parte aérea de plantas de soja inoculadas ou não com FMAs e submetidas a doses crescentes de Mn aos 90 dias.

\subsubsection{Ferro na parte aérea e raiz}

As concentrações de Fe na parte aérea, na $1^{\mathrm{a}}$ colheita, não apresentaram diferenças estatísticas significativas entre si (dados não apresentados), mas na $2^{\mathrm{a}}$ colheita, os tratamentos com FMAs diferiram dos controles, apresentando os menores valores médios de concentração de Fe na parte aérea (Fig. 13).

Observou-se também que ocorreu um aumento na concentração de Fe da $1^{\mathrm{a}}$ para a $2^{\mathrm{a}}$ colheita nos tratamentos controles e o mesmo não ocorreu com os tratamentos com FMAs (dados não apresentados).

Quanto à análise de regressão polinomial, tanto na $1^{\mathrm{a}}$ colheita quanto na $2^{\mathrm{a}}$ colheita existiu a tendência da concentração de Fe diminuir com o aumento das doses 
de Mn (Fig. 14), mostrando que a absorção de Fe é influenciada pela disponibilidade de Mn. Segundo Vitti \& Trevisan (2000), a disponibilidade dos micronutrientes pode ser influenciada pelo desbalanceamento entre cátions metálicos, causando a chamada inibição competitiva.

Este resultado obtido corrobora relatos de outros autores, como: Mengel et al. (1987) e Hati et al. (1979) apud Foy (1984), os quais concluíram que a toxidez de Mn está freqüentemente associada a baixos teores de $\mathrm{Ca}$ e $\mathrm{Fe}$ nos tecidos vegetais. Cardoso (1996a) e Nogueira \& Cardoso (2002) verificaram que a porcentagem e conteúdo total de Mn e Fe estão correlacionados inversamente em plantas micorrizadas.

$\mathrm{Na}$ raiz, a concentração de $\mathrm{Fe}$ aumentou da $1^{\mathrm{a}}$ para a $2^{\mathrm{a}}$ colheita aproximadamente 1000 vezes em todos os tratamentos (dados não apresentados).

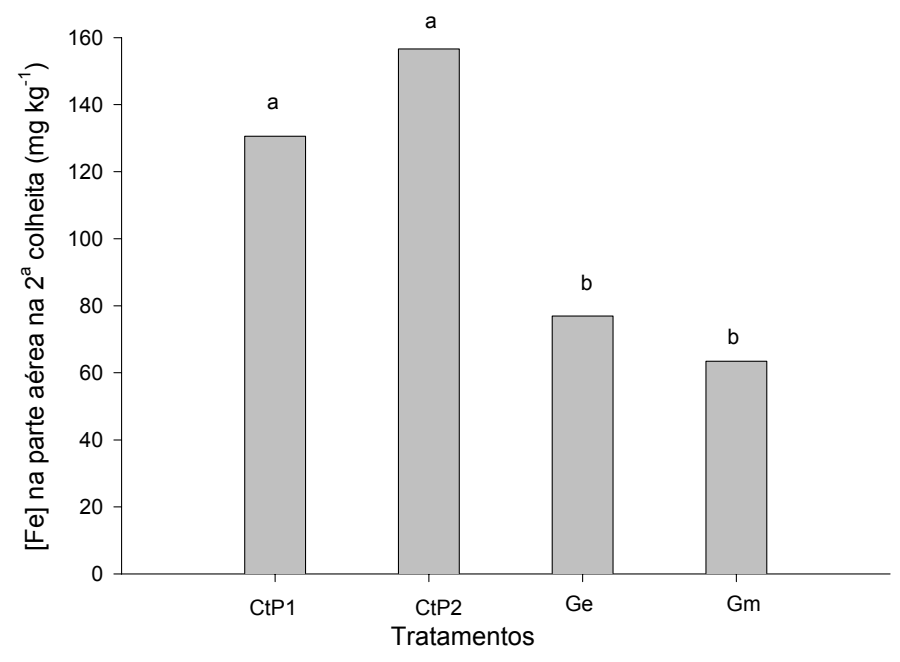

Figura 13 - Concentração de Fe na parte aérea de plantas de soja inoculadas ou não com FMAs e submetidas a doses crescentes de Mn aos 90 dias. Letras diferentes indicam diferenças significativas pelo teste de Tukey (5\%). 


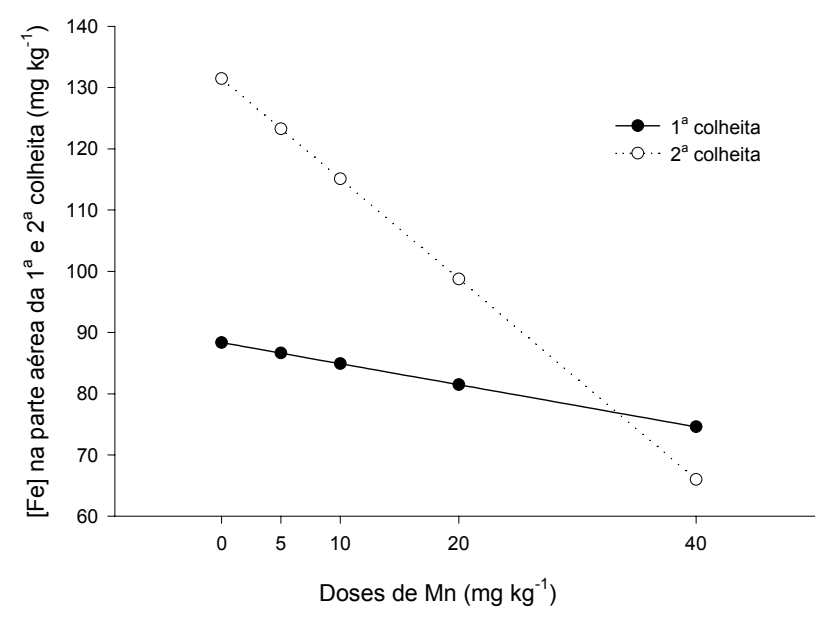

Figura 14 - Análise de regressão polinomial para a concentração de Fe na parte aérea de plantas de soja inoculadas ou não com FMAs e submetidas a doses crescentes de $\mathrm{Mn}$ aos 45 dias e 90 dias.

\subsubsection{Manganês na parte aérea e raiz}

$\mathrm{Na} 1^{\mathrm{a}}$ colheita não houve diferença significativa entre as concentrações de Mn na parte aérea das plantas dos diferentes tratamentos dentro de cada dose de Mn aplicada (Fig. 15), com exceção para a dose $40 \mathrm{mg} \mathrm{kg}^{-1}$, na qual o tratamento $\mathrm{Gm}$ apresentou o maior valor e foi significativamente diferente dos tratamentos Ge e CtP1 (Fig. 15), enquanto o Ge apresentou o menor valor de concentração de Mn e diferiu dos tratamentos CtP2 e Gm (Fig. 15). Entretanto, a concentração de Mn foliar foi crescente com aumento da dose de $\mathrm{Mn}$, tanto na $1^{\mathrm{a}}$ quanto na $2^{\mathrm{a}}$ colheita (Fig 16 e 18 ).

$\mathrm{Na} 2^{\mathrm{a}}$ colheita, o tratamento $\mathrm{Gm}$ apresentou o menor valor médio de concentração de Mn e diferiu significativamente dos tratamentos CtP1 e CtP2. O 
tratamento Ge diferiu apenas do Ctp1, o qual apresentou maior valor médio de concentração de Mn na parte aérea (Fig. 17). Este resultado está de acordo com dados anteriores de Cardoso (1996a), que relatou que a presença do FMA pode reduzir a concentração de Mn quando comparado à planta controle.

A parte aérea apresentou maior concentração de Mn ( 200 a 1000 mg $\left.\mathrm{kg}^{-1}\right)$ que a raiz $\left(\sim 100\right.$ a $\left.450 \mathrm{mg} \mathrm{kg}^{-1}\right)\left(\right.$ Fig. 18 e 20) na $2^{\mathrm{a}}$ colheita. Isto é contrário aos dados obtidos por Navarro \& Cardoso (1992).

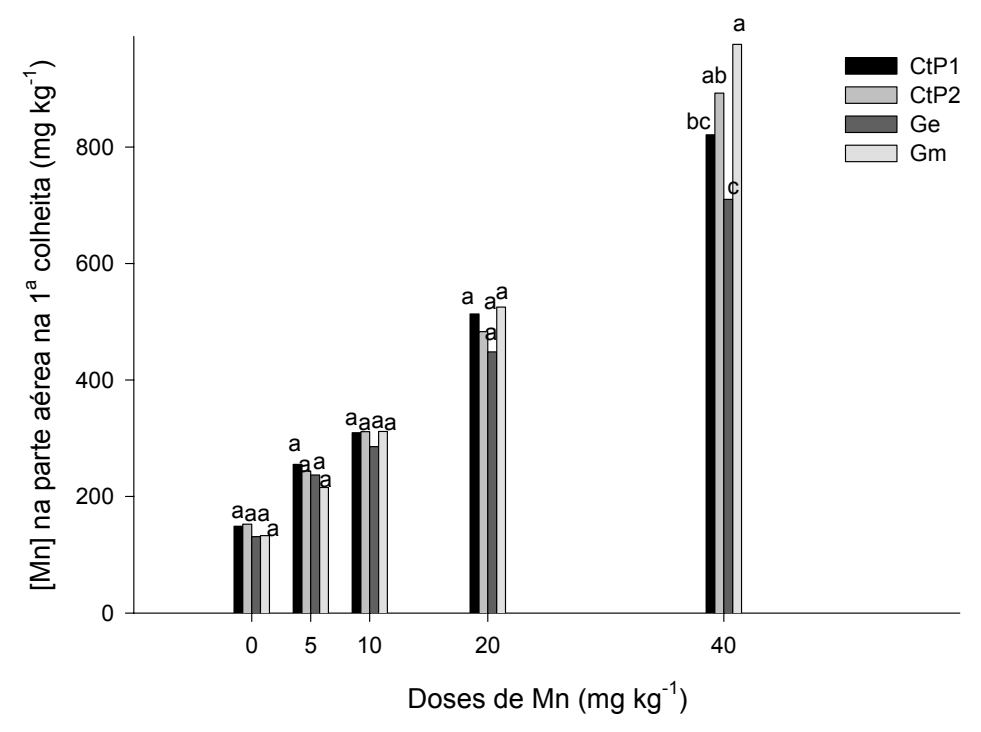

Figura 15 - Concentração de Mn na parte aérea de plantas de soja inoculadas ou não com FMAs e submetidas a doses crescentes de Mn aos 45 dias. Letras diferentes indicam diferenças significativas pelo teste de Tukey (5\%). 


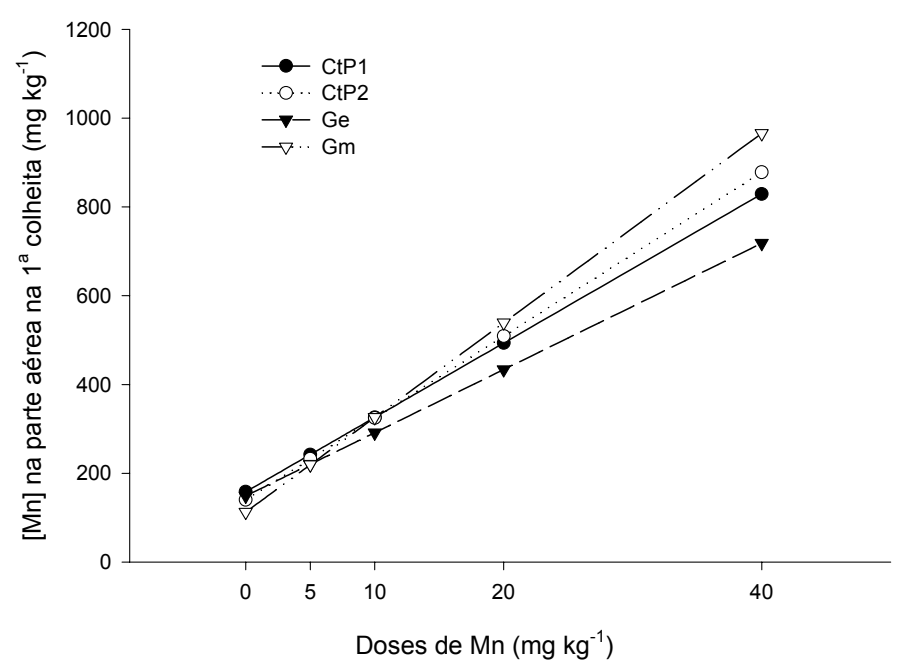

Figura 16 - Análise de regressão polinomial para a concentração de Mn na parte aérea de plantas de soja inoculadas ou não com FMAs e submetidas a doses crescentes de Mn aos 45 dias.

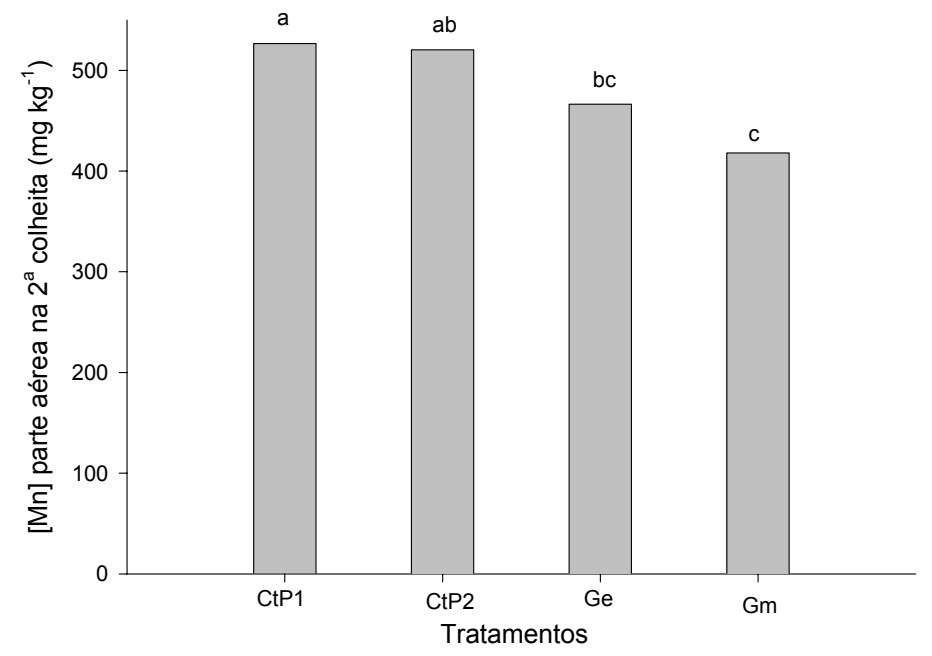

Figura 17 - Concentração de Mn na parte aérea de plantas de soja inoculadas ou não com FMAs e submetidas a doses crescentes de Mn aos 90 dias. Letras diferentes indicam diferenças significativas pelo teste de Tukey (5\%). 


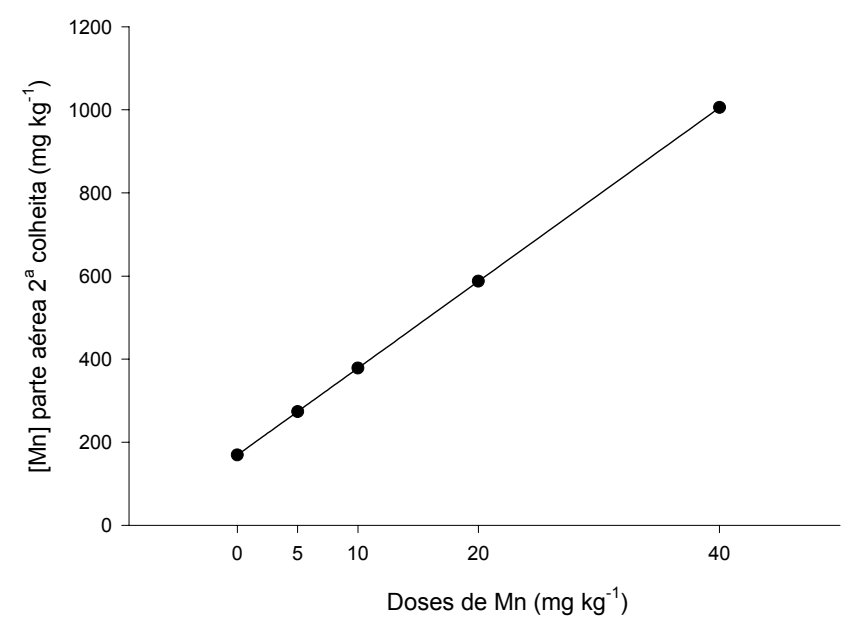

Figura 18 - Análise de regressão polinomial para a concentração de Mn na parte aérea de plantas de soja inoculadas ou não com FMAs e submetidas a doses crescentes de Mn aos 90 dias.

Os valores da concentração de $\mathrm{Mn}$ na raiz obtidos na $1^{\mathrm{a}}$ colheita não foram analisados estatisticamente, pois as amostras não apresentaram massa suficiente para a análise em cada repetição, tendo estas sidas analisadas em conjunto. A tendência das curvas nas duas colheitas mostrou que em todos os tratamentos ocorreu um aumento da concentração de Mn na raiz, de acordo com o aumento das doses de Mn (Fig. 19 e 20).

$\mathrm{Na} 2^{\mathrm{a}}$ colheita os valores médios de concentração de $\mathrm{Mn}$ na raiz mostraram que os tratamentos com FMAs não diferiram entre si e do CtP2, mas foram inferiores aos do CtP1 (Fig. 21), o que reforça a observação que as plantas micorrizadas apresentam um fator de proteção contra a absorção excessiva de Mn, quando em altos níveis deste nutriente. Deve-se realçar que o P é antagônico ao Mn (Fig. 10) e o CtP2 apresenta teores de Mn semelhantes aos das plantas micorrizadas e menores do que o CtP1, mais deficiente em P. 
Cardoso (1996a) verificou que plantas não micorrizadas apresentavam evidentes sintomas de toxidez de $\mathrm{Mn}$ enquanto plantas micorrizadas quase não mostravam sintomas de toxidez de Mn, mesmo com baixos níveis de P aplicados. Este resultado sugere o efeito de proteção à toxicidade de Mn em plantas micorrizadas.

Os níveis de concentração de Mn para que uma planta produza os sintomas de toxidez variam de acordo com a espécie da planta, o genótipo, as condições ambientais e a temperatura. Em algumas espécies, a baixa absorção e alta retenção de Mn na raiz parece ser importante para a tolerância ao Mn. O Mn interage com muitos outros minerais na nutrição da planta e, sob certas condições, a adição dos elementos $\mathrm{Si}$, $\mathrm{Fe}, \mathrm{Ca}, \mathrm{P}$ alivia a toxidez de $\mathrm{Mn}$. A adição de $\mathrm{P}$ pode reduzir a toxicidade de $\mathrm{Mn}$ por render o elemento inativo na planta (Foy, 1984). Também foi mostrado por Cardoso (1996a) que a fonte de $\mathrm{P}$ pode interferir na absorção de micronutrientes em plantas, pois o uso de duas fontes diferenciadas de $\mathrm{P}$ em plantas micorrizadas e não micorrizadas, mostrou efeito diferenciado na aquisição e translocação do Mn nessas plantas.

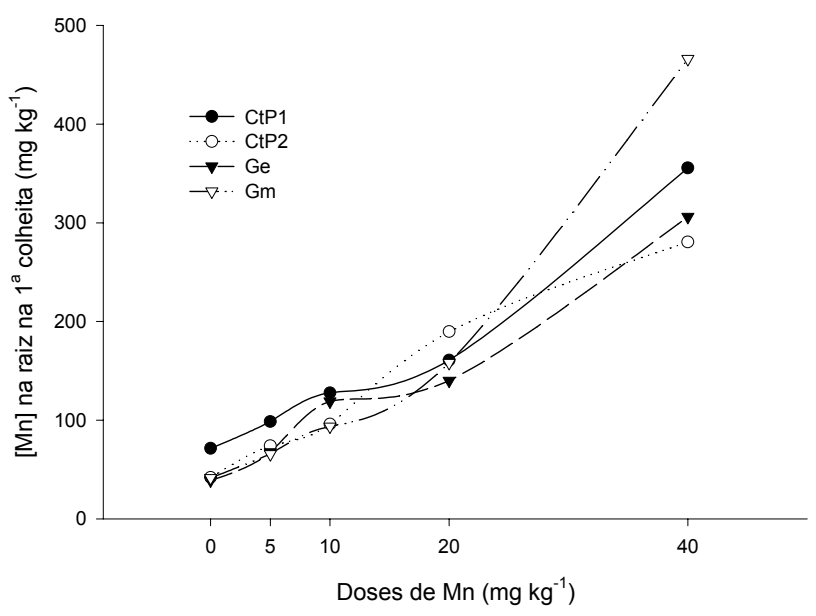

Figura 19 - Análise de regressão polinomial para a concentração de Mn na raiz de plantas de soja inoculadas ou não com FMAs e submetidas a doses crescentes de Mn aos 45 dias. 


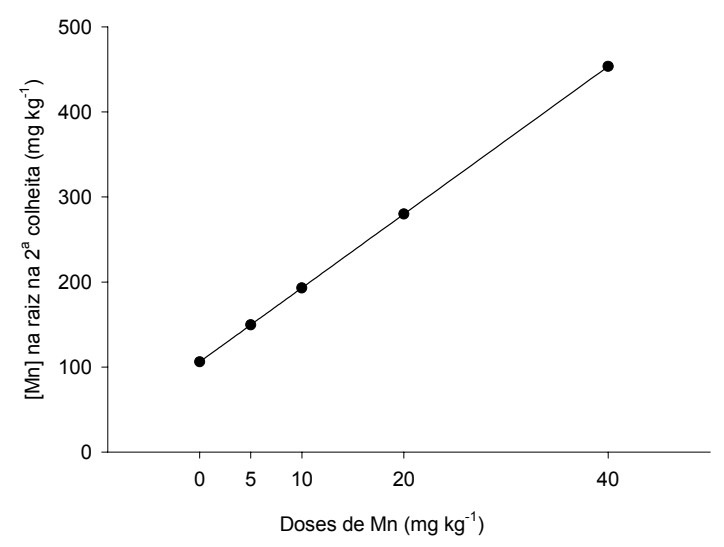

Figura 20 - Análise de regressão polinomial para a concentração de Mn na raiz de plantas de soja inoculadas ou não com FMAs e submetidas a doses crescentes de Mn aos na 90 dias.

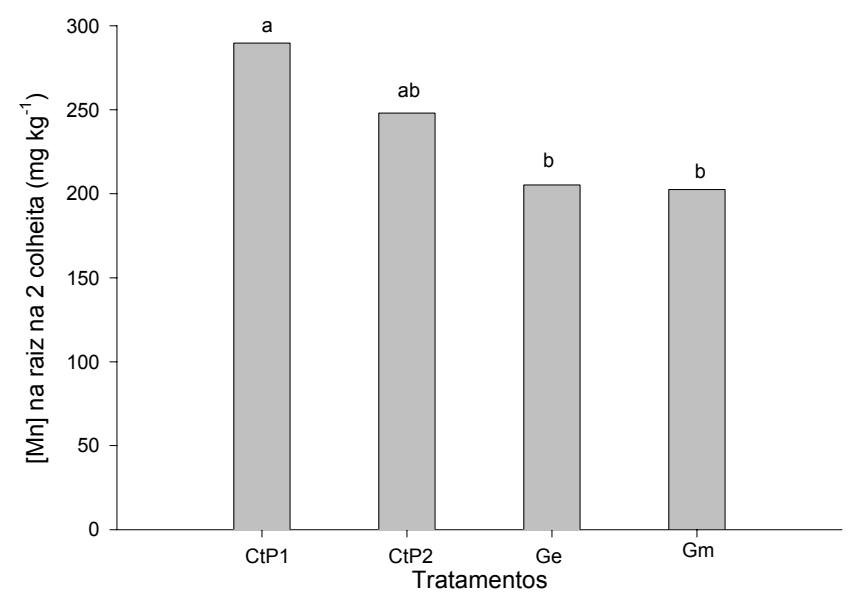

Figura 21 - Concentração de Mn na raiz de plantas de soja inoculadas ou não com FMAs e submetidas a doses crescentes de Mn aos 90 dias. Letras diferentes indicam diferenças significativas pelo teste de Tukey $(5 \%)$. 


\subsection{Análise da atividade enzimática}

As atividades das enzimas foram determinadas em raiz e folha de plantas de soja submetidas às doses $0,5,10,20 \mathrm{e} 40 \mathrm{mg} \mathrm{kg}^{-1}$ de $\mathrm{Mn}$ adicionado ao substrato. Foram realizadas pré-análises dos géis para determinar padrões de concentração de proteínas e verificou-se que o resultado de atividade enzimática nas doses 5 e $10 \mathrm{mg} \mathrm{kg}{ }^{-}$

${ }^{1}$ de $\mathrm{Mn}$ apresentou a mesma tendência que aquela na testemunha (dose $0 \mathrm{mg} \mathrm{kg}^{-1}$ de $\mathrm{Mn}$ adicionado), portanto, decidiu-se que apenas as doses 0,20 e $40 \mathrm{mg} \mathrm{kg}^{-1}$ de $\mathrm{Mn}$ adicionado seriam avaliadas. Para o preparo dos géis de eletroforese cada canaleta do gel representa um tratamento.

\subsubsection{Atividade de Peroxidase}

\subsubsection{Folha}

Na visualização do gel do extrato foliar da $1^{\text {a }}$ colheita (Fig. 22) observouse a presença de duas isoformas, entre as quais a primeira (maior peso molecular) se destacou pela maior atividade. Nas plantas do CtP1 verificou-se maior atividade de peroxidase nas doses 0 e $20 \mathrm{mg} \mathrm{kg}^{-1}$ de $\mathrm{Mn}$ e nos demais tratamentos (CtP2, Ge e $\mathrm{Gm}$ ) sempre houve maior atividade na dose $40 \mathrm{mg} \mathrm{kg}^{-1}$ de Mn (Fig. 22). O resultado da atividade enzimática parece condizer com a quantidade de MST (Fig. 4). Nesta $1^{\mathrm{a}}$ colheita, as plantas do CtP1 que apresentaram menor crescimento que as plantas do CtP2 devido a menor aplicação de $\mathrm{P}$, estariam em condições desfavoráveis ao seu desenvolvimento normal, portanto esta condição de estresse levaria a planta a apresentar alterações metabólicas, com a produção de enzimas antioxidativas para suprir a condição desfavorável e eliminar os efeitos estressantes, tendo então, estas plantas, uma maior atividade enzimática. 


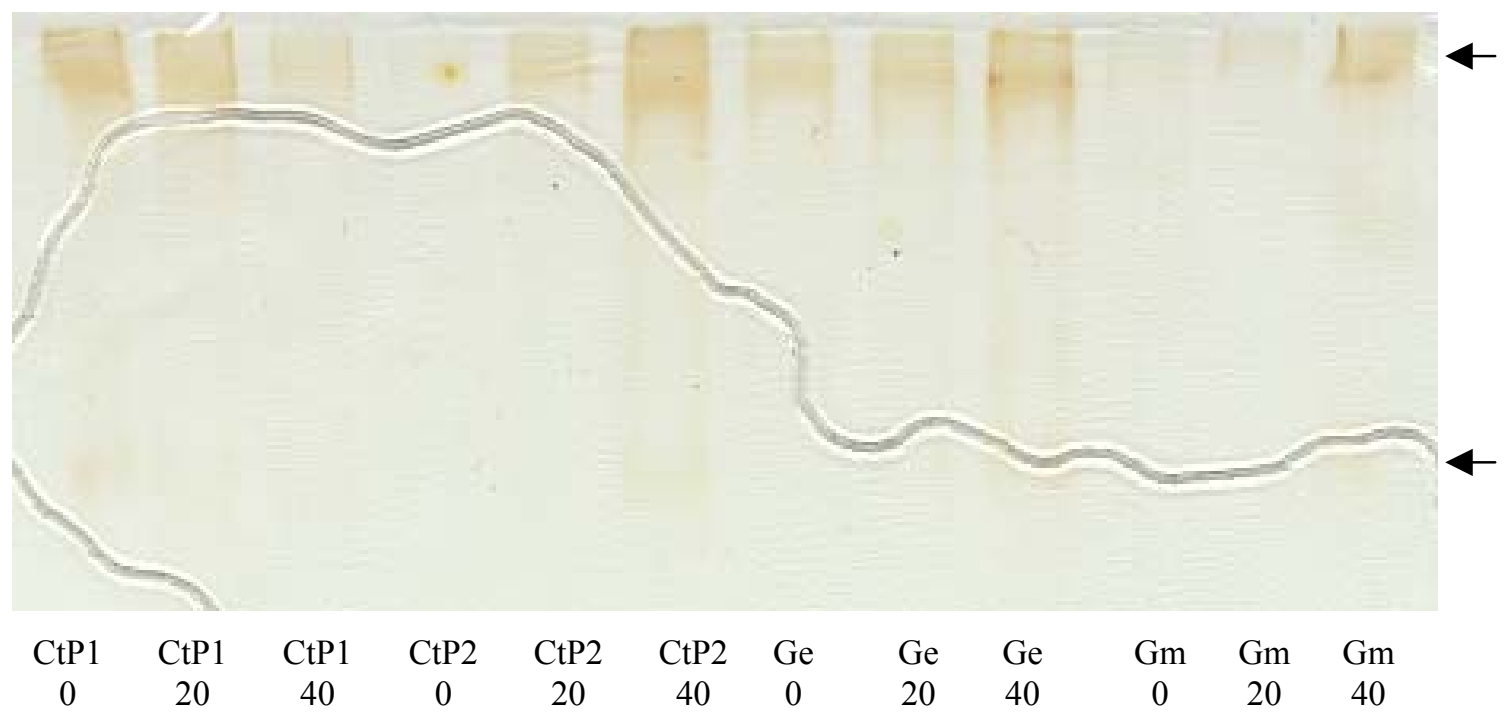

Figura 22 - Padrão eletroforético em gel de poliacrilamida para peroxidase com extrato foliar de plantas de soja, que receberam duas doses de P (controles P1 e P2) e inoculadas com os FMAs Glomus etunicatum (Ge) e Glomus macrocarpum $(\mathrm{Gm})$ em dose P1, após 45 dias de crescimento nas doses 0, 20 e $40 \mathrm{mg} \mathrm{kg}^{-1}$ de Mn adicionado ao substrato. As setas indicam a posição das principais isoformas. 
As plantas dos tratamentos CtP2, Ge e Gm parecem mostrar um limite de tolerância ao estresse de $\mathrm{Mn}$ até a dose $20 \mathrm{mg} \mathrm{kg}^{-1}$ de $\mathrm{Mn}$, pois apenas na dose $40 \mathrm{mg}$ $\mathrm{kg}^{1}$ de $\mathrm{Mn}$ estas apresentaram maior atividade enzimática que as demais.

Assumindo-se que a maior atividade da enzima peroxidase reflita uma condição de maior estresse (Gaspar et al. 1985), isto possivelmente ocorreu nas plantas do CtP1, visto que estas receberam menos $\mathrm{P}$ e, devido a este estresse nutricional, apresentaram menor crescimento (Fig. 4) e maior expressão dos sintomas de toxidez de Mn (Fig. 2). Também pode ter ocorrido nas plantas do CtP2, Ge e Gm, somente na dose $40 \mathrm{mg} \mathrm{kg}^{-1}$ de Mn.

Ainda aos 45 dias ( $1^{\text {a }}$ colheita), seria de se esperar que as plantas inoculadas com FMAs apresentassem maior ou igual atividade enzimática que o CtP1, pois ambas estavam em condições de estresse, as segundas (CtP1) por receberem menor dose de $\mathrm{P}$ e as primeiras (Ge e $\mathrm{Gm})$, por estarem em início de colonização radicular e a micorriza ainda estar incipiente, ocorrendo um dreno adicional de $\mathrm{C}$ na planta (Fig. 6). No entanto, este fato não ocorreu, pois as plantas inoculadas com FMAs apresentaram menor atividade enzimática do que as demais (Fig. 22). $\mathrm{Na} 2^{\mathrm{a}}$ colheita, no gel com extrato foliar, foram observadas quatro isoformas de peroxidase (Fig. 23). Considerando-se a primeira isoforma (maior peso molecular), as plantas do CtP1 e Ge na dose $40 \mathrm{mg} \mathrm{kg}^{-1}$ de $\mathrm{Mn}, \mathrm{CtP} 2$ na dose $0 \mathrm{mg} \mathrm{kg}^{-1}$ de $\mathrm{Mn}$ e Gm nas doses 20 e $40 \mathrm{mg}$ $\mathrm{kg}^{-1}$ de $\mathrm{Mn}$ apresentaram maior atividade (comparando-se dentro de cada tratamento de inoculação). A maior freqüência de aparecimento da maior atividade na dose $40 \mathrm{mg} \mathrm{kg}^{-1}$ de $\mathrm{Mn}$ novamente sugere que a maior atividade da enzima peroxidase reflita uma condição de maior estresse (Gaspar et al. 1985). Entretanto, se compararmos a segunda e terceira isoformas (peso molecular intermediário), as plantas que apresentaram maior atividade enzimática foram as do CtP1, CtP2, Ge e $\mathrm{Gm}$ na dose $0 \mathrm{mg} \mathrm{kg}^{-1}$ de $\mathrm{Mn}$ (Fig. 23). Este resultado sugere que algumas isoformas apresentam respostas diferenciadas de atividade enzimática em situação de ausência do estresse de Mn.

Apenas as plantas do tratamento Ge na dose $20 \mathrm{mg} \mathrm{kg}^{-1}$ de $\mathrm{Mn}$ apresentaram a última isoforma (menor peso molecular). 


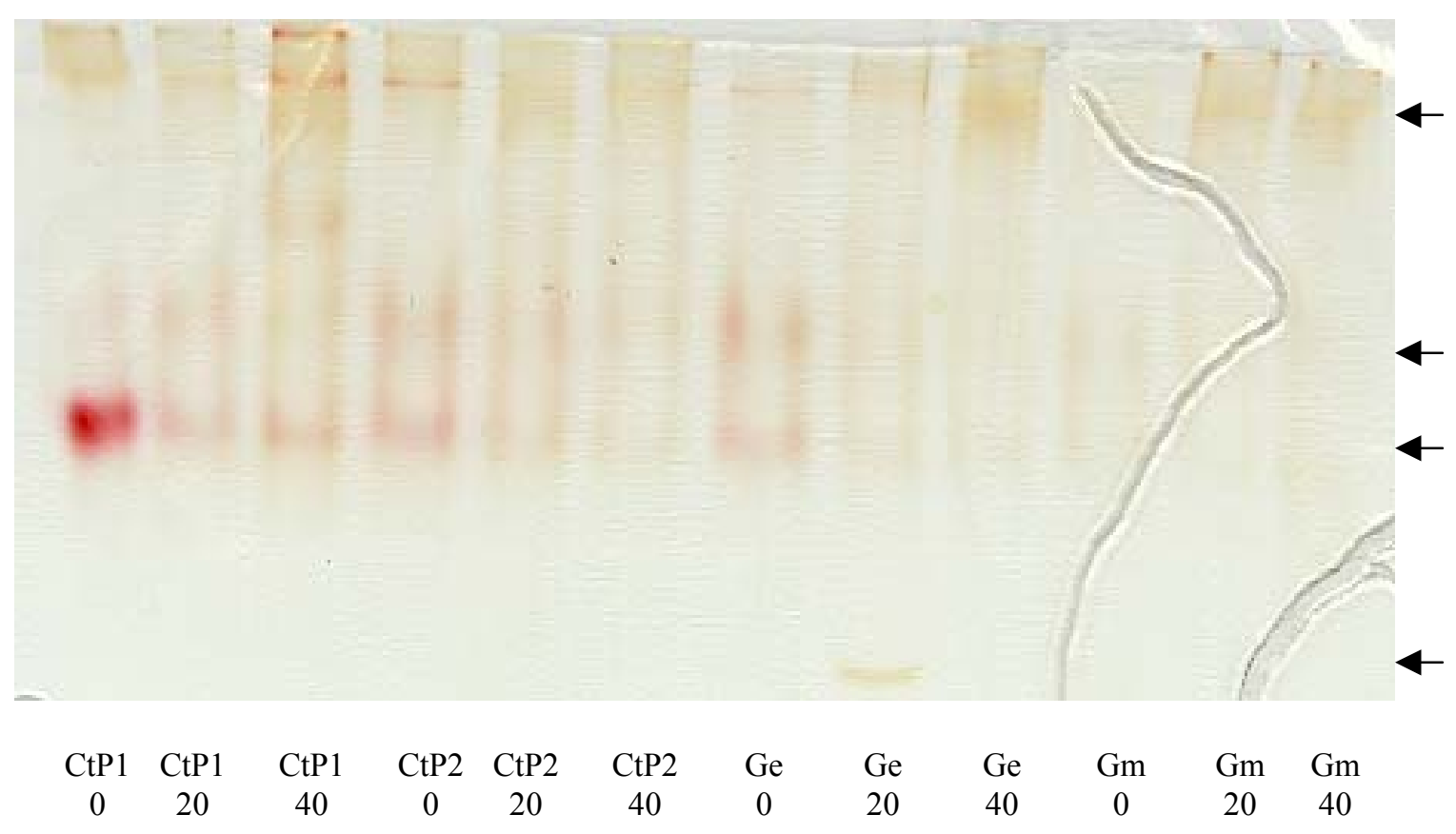

Figura 23 - Padrão eletroforético em gel de poliacrilamida para peroxidase com extrato foliar de plantas de soja, que receberam duas doses de P (controles P1 e P2) e inoculadas com os FMAs Glomus etunicatum (Ge) e Glomus macrocarpum $(\mathrm{Gm})$ em dose P1, após 90 dias de crescimento nas doses 0, 20 e $40 \mathrm{mg} \mathrm{kg}^{-1}$ de $\mathrm{Mn}$ adicionado ao substrato. As setas indicam a posição das principais isoformas. 


\subsubsection{Raiz}

O gel com extrato de raiz, na $1^{\mathrm{a}}$ colheita, apresentou nove isoformas (Fig. 24), das quais a primeira isoforma (maior peso molecular) se sobressaiu com maior atividade nas plantas do CtP1 nas doses 0 e $20 \mathrm{mg} \mathrm{kg}^{-1}$ de $\mathrm{Mn}$. As plantas do CtP2 apresentaram atividade enzimática semelhante nas três doses de $\mathrm{Mn}\left(0,20\right.$ e $\left.40 \mathrm{mg} \mathrm{kg}^{-1}\right)$. As do Ge, na dose $20 \mathrm{mg} \mathrm{kg}^{-1}$ de $\mathrm{Mn}$, seguida da dose $0 \mathrm{mg} \mathrm{kg}^{-1}$ de $\mathrm{Mn}$, e as do $\mathrm{Gm}$, na dose $0 \mathrm{mg} \mathrm{kg}^{-1}$ de $\mathrm{Mn}$, apresentaram maior atividade de peroxidase (Fig. 24).

A terceira isoforma foi a que mais se destacou e a presença das demais isoformas ( $\mathrm{da} 4^{\mathrm{a}}$ a $9^{\mathrm{a}}$ ) foi observada em maior destaque nos tratamentos CtP1 na dose 20 e $40 \mathrm{mg} \mathrm{kg}^{-1}$ de $\mathrm{Mn}$ e Ge na dose $40 \mathrm{mg} \mathrm{kg}^{-1}$ de Mn (Fig 24). Não existiu uma tendência clara na atividade enzimática entre os tratamentos tanto para a primeira quanto para a terceira isoforma e por isso, não foi possível encontrar explicações plausíveis para estas observações.

$\mathrm{Na} 2^{\mathrm{a}}$ colheita foram observadas cinco isoformas (Fig. 25), duas delas apareceram em todos os tratamentos ( $1^{\mathrm{a}}$ e $2^{\mathrm{a}}$ isoformas). A primeira isoforma (maior peso molecular) apresentou maior atividade enzimática nas plantas do tratamento CtP1 que, entre as doses de Mn, não apresentou diferença de atividade, e nas plantas do CtP2, Ge e $\mathrm{Gm}$ na dose $20 \mathrm{mg} \mathrm{kg}^{-1}$ de Mn (Fig. 25). A segunda isoforma mostrou maior atividade em todas as doses de todos os tratamentos de inoculação (com e sem micorriza), com maior destaque para as plantas do tratamento CtP1 nas doses 0, 20 e 40 $\mathrm{mg} \mathrm{kg}{ }^{-1}$ de $\mathrm{Mn}, \mathrm{CtP} 2$ nas doses 20 e $40 \mathrm{mg} \mathrm{kg}^{-1}$ de $\mathrm{Mn}$, Ge nas doses 0 e $20 \mathrm{mg} \mathrm{kg}^{-1}$ de Mn e $\mathrm{Gm}$ na dose $40 \mathrm{mg} \mathrm{kg}^{-1}$ de $\mathrm{Mn}$. As demais isoformas (da $3^{\mathrm{a}}$ a $5^{\mathrm{a}}$ ) mostraram pouca atividade enzimática e sobressaíram-se apenas em plantas inoculadas com FMAs (Fig. 25).

Na observação do gel de raiz na $2^{\text {a }}$ colheita, no qual o CtP1 apresentou maior atividade enzimática em todas as doses e o Gm a menor atividade (Fig. 25), foi feita uma analogia com os resultados anteriores de MST (Fig. 4) e quantidade de P aplicada nos tratamentos. As plantas do CtP1, nesta colheita, estavam em condições desaforáveis para um desenvolvimento normal. Neste período as plantas estão em fase 


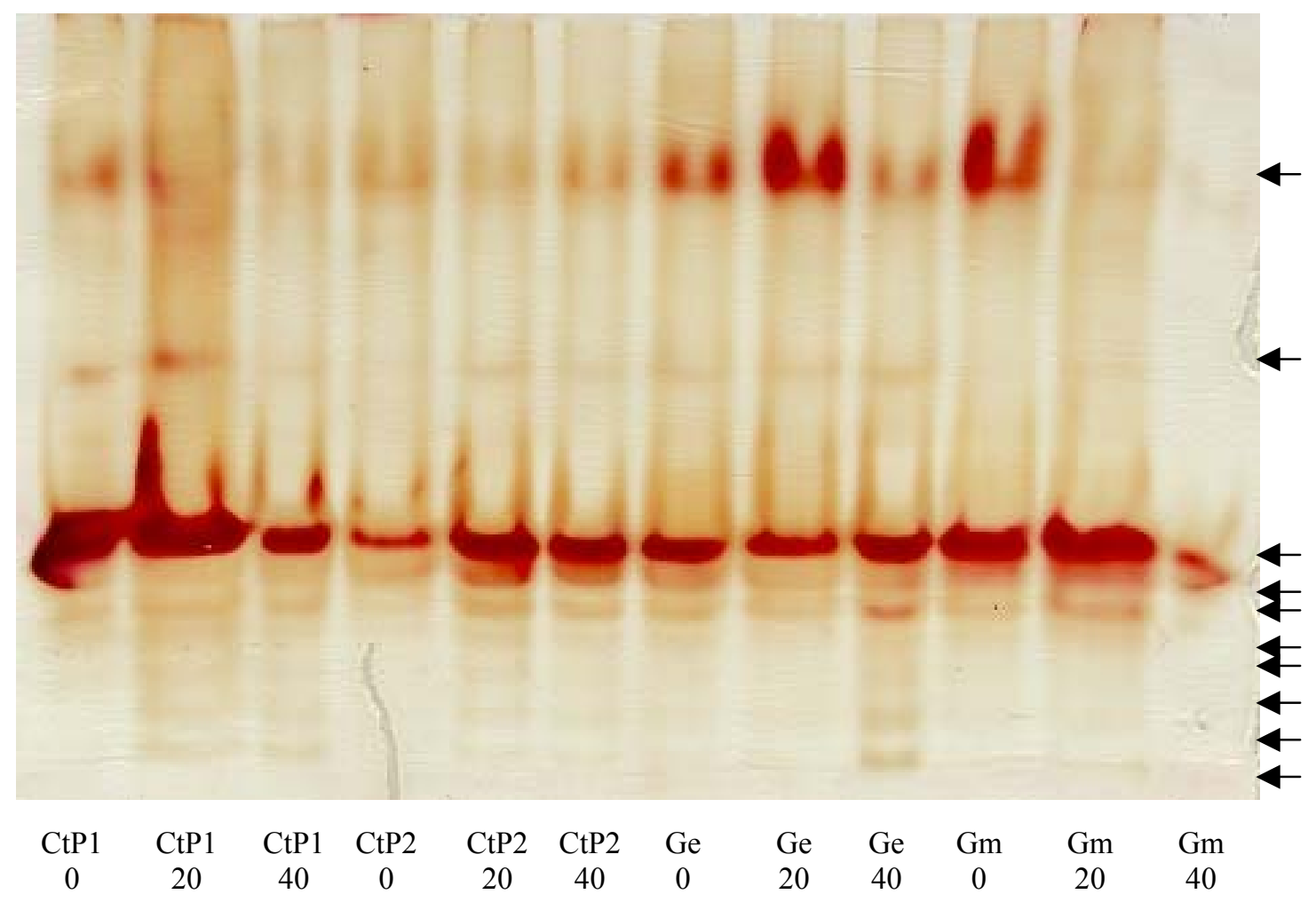

Figura 24 - Padrão eletroforético em gel de poliacrilamida para peroxidase com extrato de raiz de plantas de soja, que receberam duas doses de P (controles P1 e P2) e inoculadas com os FMAs Glomus etunicatum (Ge) e Glomus macrocarpum $(\mathrm{Gm})$ em dose P1, após 45 dias de crescimento nas doses 0, 20 e $40 \mathrm{mg} \mathrm{kg}^{-1}$ de Mn adicionado ao substrato. As setas indicam a posição das principais isoformas. 


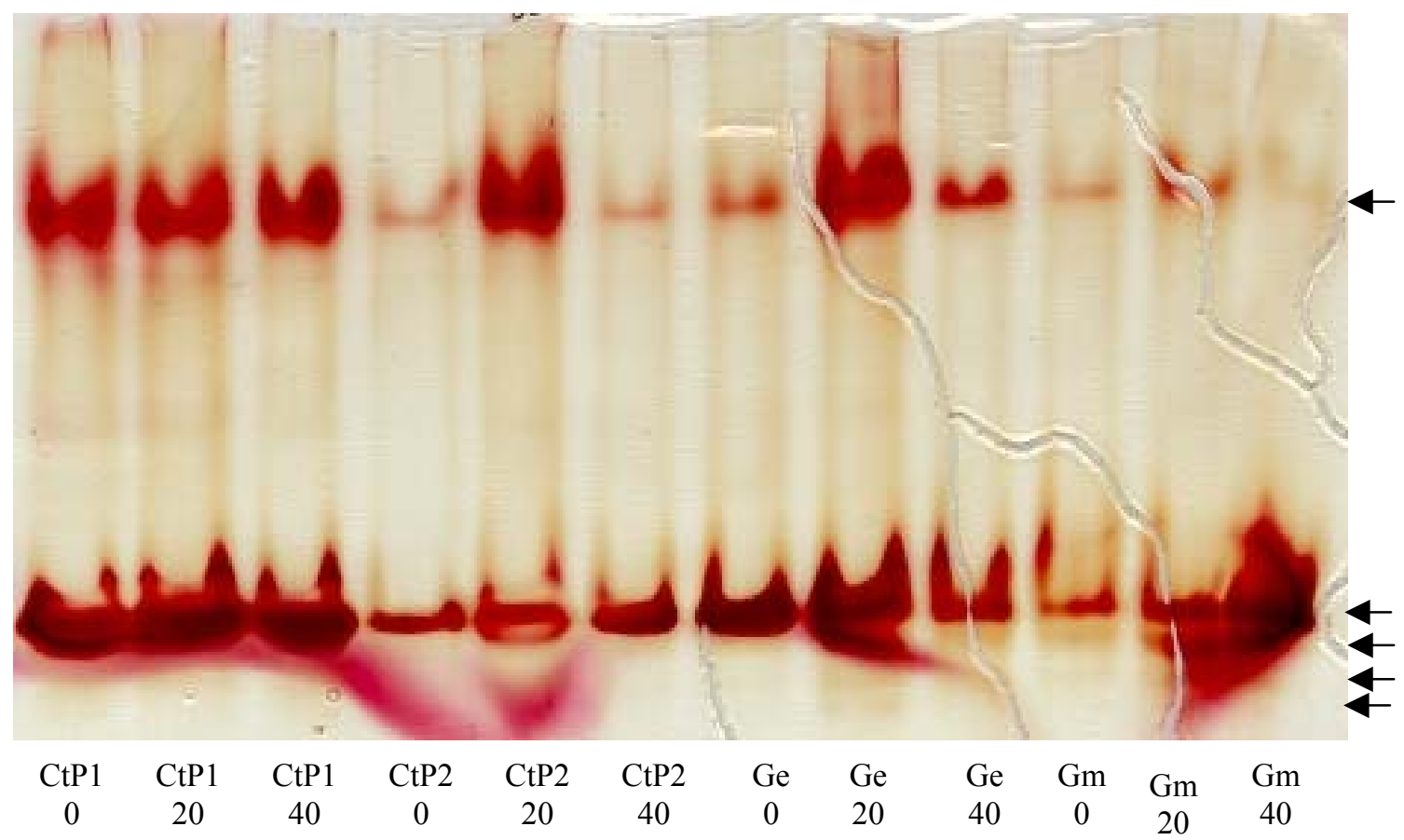

Figura 25 - Padrão eletroforético em gel de poliacrilamida para peroxidase com extrato de raiz de plantas de soja, que receberam duas doses de P (controles P1 e P2) e inoculadas com os FMAs Glomus etunicatum (Ge) e Glomus macrocarpum $(\mathrm{Gm})$ em dose P1, após 90 dias de crescimento nas doses 0, 20 e $40 \mathrm{mg} \mathrm{kg}^{-1}$ de $\mathrm{Mn}$ adicionado ao substrato. As setas indicam a posição das principais isoformas. 
de floração, necessitando de uma nutrição mineral ideal para o desenvolvimento normal, portanto estas, como receberam menor dose de $\mathrm{P}$, apresentaram uma deficiência nutricional deste elemento e conseqüente diminuição do crescimento. Considera-se então que as plantas do CtP1 estavam em condições de estresse nutricional, pela deficiência de $\mathrm{P}$ e excesso de Mn, tiveram o metabolismo antioxidativo alterado e conseqüente incremento da maior atividade enzimática. Os demais tratamentos (CtP2, Ge e $\mathrm{Gm}$ ), nesta mesma época, estavam em melhores condições nutricionais que as plantas do CtP1. As plantas do CtP2, por possuírem maior aplicação de $\mathrm{P}$, apresentavam uma nutrição mineral de $\mathrm{P}$ suficiente para um melhor desenvolvimento. No caso das plantas com FMAs, apesar de estarem em condição nutricional desfavorável (menor aplicação de P) já tinham instalado uma colonização micorrízica eficiente que ajudou na maior absorção de $\mathrm{P}$, suprindo sua falta. Estas condições permitiram um maior crescimento das plantas, considerando-se então estarem em condições favoráveis para seu desenvolvimento, mesmo que em excesso de Mn, produzindo menor quantidade de enzimas antioxidativas, apresentando menor atividade enzimática.

$\mathrm{O}$ resultado obtido de maior atividade de peroxidase para as plantas que estão em situações de maior estresse (discutidas no parágrafo anterior) é semelhante ao do trabalho de Leidi et al. (1986) que estudaram o efeito do Mn nas diferentes variedades de soja e observaram que existiu uma correlação inversa entre crescimento e atividade de peroxidase, ocorrendo a diminuição do crescimento da planta e aumento da atividade de peroxidase. Cakmak \& Horst (1991) estudaram o efeito do alumínio no crescimento de raízes de soja e nas atividades enzimáticas relacionadas à produção de espécies ativas de oxigênio (EAOs) e observaram o aumento da atividade enzimática de peroxidase nas raízes que tiveram menor crescimento. Em casos de toxicidade causada por oxigênio (Foster \& Hess 1980) e Fe (Hendry \& Brocklebank 1985), respostas semelhantes foram encontradas.

Trabalhos como estes mostram que, apesar de alguns autores estudarem fatores estressantes diferentes do Mn, obtiveram a mesma resposta de aumento de atividade de peroxidase em situações de estresse. 
Os resultados obtidos foram muito variados. Cada isoforma é expressa de uma maneira. Cada extrato utilizado, grupo de tratamentos de inoculação e diferentes doses de Mn apresentaram respostas diferenciadas. Fica muito difícil, a partir das observações dos géis, especificar onde a enzima peroxidase apresentou maior atividade global e chegar a alguma conclusão geral. Apesar disso, foram observadas algumas tendências discutidas a seguir.

$\mathrm{Na} 1^{\mathrm{a}}$ (Fig 22) e $2^{\mathrm{a}}$ colheita (Fig 23), exclusivamente no extrato foliar e na primeira isoforma (maior peso molecular), existe uma forte indicação de que a maior atividade tenha correspondido à maior dose de $\mathrm{Mn}\left(40 \mathrm{mg} \mathrm{kg}^{-1}\right)$ nas plantas do tratamento CtP1, CtP2, Ge e $\mathrm{Gm}$, embora isto não tenha ocorrido nas plantas do CtP1(Fig. 22), na $1^{\text {a }}$ colheita e nas do CtP2, na $2^{\text {a }}$ colheita (Fig. 23). Todos os tratamentos diminuíram a quantidade de MST em consonância com o aumento das doses de Mn (Fig 4), e isto sugere que o excesso de Mn nas plantas leva a uma alteração metabólica, produzindo maior quantidade de enzimas antioxidativas e conseqüentemente maior atividade enzimática.

Entretanto, outras isoformas mostraram maior atividade de peroxidase principalmente na dose $0 \mathrm{mg} \mathrm{kg}^{-1}$ de Mn, no extrato foliar (Fig 23) e na dose $20 \mathrm{mg} \mathrm{kg}^{-1}$ de Mn, no extrato de raiz (Fig. 24 e 25), dentro de cada tratamento de inoculação. Portanto, sugere-se que a peroxidase apresente algumas isoformas que são ativadas com o aumento da dose de Mn no substrato da planta, podendo ser consideradas tipicamente como responsivas a um fator estressante. Outras isoformas, no entanto, parecem mostrar maior atividade enzimática justamente no tratamento em que não houve adição de Mn e não poderiam ser consideradas como responsivas a este fator estressante. Ainda, poderse-ia sugerir que a presença do Mn inibiria a atividade de algumas isoformas dessa enzima.

A menor atividade enzimática das plantas com FMAs, especificamente do Gm, na $2^{\mathrm{a}}$ colheita, tanto no extrato foliar (isoformas com menor peso molecular; Fig 23) quanto no de raiz (isoformas com maior peso molecular; Fig. 25), parece indicar que plantas micorrizadas amenizam a situação de estresse de Mn, pois apresentaram resposta 
contrária à reposta das plantas sem inoculação de FMAs (CtP1 e CtP2), que estavam nas mesmas condições desfavoráveis, em estresse de excesso de Mn.

De acordo com a hipótese deste trabalho, esperaríamos que a atividade da peroxidase estivesse aumentada na $1^{\mathrm{a}}$ época de colheita nos tratamentos CtP1 (por ter recebido menor dose de $\mathrm{P}$ ) e principalmente nos tratamentos Ge e Gm (que, além de terem recebido menor dose de $\mathrm{P}$, estavam em processo de micorrização e a simbiose nesta época ainda não estava totalmente estabelecida, representando um dreno adicional de $\mathrm{C}$ ). $\mathrm{Na} 2^{\mathrm{a}}$ época esperar-se-ia aumento da atividade desta enzima apenas no tratamento CtP1, sendo que as plantas do CtP2, Ge e Gm (agora com simbiose plenamente estabelecida) estariam bem menos estressadas, portanto com menor atividade de peroxidase. Aliás, os resultados obtidos para biomassa vegetal, colonização micorrízica e teor de $\mathrm{P}$ na planta corroboraram totalmente esta hipótese. Já no caso da peroxidase houve grande variabilidade no aumento da sua atividade entre os diferentes tratamentos, nem sempre concordando com a expectativa apresentada.

Considerando-se, ainda, que o aumento da dose de Mn deve representar aumento do estresse sofrido pela planta, também seria de se esperar que fosse verificado o aumento da atividade de peroxidase na maior dose de $\mathrm{Mn}$ (40 $\mathrm{mg} \mathrm{kg}^{-1}$ ). Esta expectativa também só ocorreu em alguns casos, sendo que diversas vezes verificou-se aumento da atividade em doses mais baixas de Mn e nos tratamentos com FMAs na $2^{\mathrm{a}}$ colheita que, de fato, apresentavam a menor toxidez de Mn, conforme já discutido anteriormente.

Diante desta constatação fica impossível estabelecer com precisão quais são os fatores de estresse que levaram plantas de determinados tratamentos a terem sua atividade enzimática aumentada e sugere-se que estes fatores aqui detalhados devem ter contribuído para as respostas observadas. Entretanto, outros fatores, alheios ao nosso controle, podem ter interferido na expressão da atividade enzimática nos diferentes tratamentos.

Apesar de mecanismos fisiológicos de toxicidade e tolerância ao $\mathrm{Mn}$ ainda serem desconhecidos, vários artigos sugerem que o excesso de $\mathrm{Mn}$ induz o estresse oxidativo, levando ao aumento da atividade de enzimas antioxidativas. Assim, 
González et al. (1998) estudaram o efeito da intensidade da luz em enzimas antioxidantes e conteúdo de clorofila em Phaseolus vulgaris L. exposto ao excesso de Mn e observaram que durante dez dias de excesso de Mn, as folhas aumentaram a atividade da ascorbato-peroxidase em $78 \%$ com pouca luminosidade e em $235 \%$ com muita luminosidade. Leidi et al. (1987) estudaram as diferenças genéticas da soja em resposta ao Fe e Mn e atividade das metaloenzimas e concluíram que o estresse de Mn (deficiência ou toxidez) aumenta a atividade de peroxidase em plantas intolerantes e tolerantes à toxidez de $\mathrm{Mn}$.

Já em outros trabalhos foi relatado que o estresse causado por diversos fatores diminuiu a atividade de peroxidase. Assim, Balestrasse et al. (2001) estudaram a resposta do sistema de defesa antioxidativo em nódulos e raízes de soja submetidos ao excesso de cádmio e observaram que a enzima ascorbato-peroxidase diminuiu a atividade nas raízes de soja com excesso de $\mathrm{Cd}$, em relação aos tratamentos controles. Rossi et al. (1997) estudaram a atividade de peroxidase em folha e raiz de Phaseolus vulgaris L. cultivado em condições de salinidade e observaram que a atividade da enzima apresentou uma redução sensível nas plantas cultivadas com $\mathrm{NaCl}$ quando comparadas com as plantas cultivadas em solução nutritiva completa sem $\mathrm{NaCl}$. Silva et al. (2000) estudaram alterações dos padrões de isoenzimas em sementes de milho infectadas por fungos (Aspergillus flavus, Fusarium moniliforme e Penicillium spp.) e verificaram que a intensidade de bandas da peroxidase foi reduzida nas sementes infectadas em comparação às sementes não infectadas com fungos.

Poucos estudos são relacionados à atividade da enzima em plantas associadas com FMAs e nenhum destes está ligado ao efeito da micorrização em plantas com toxidez de Mn. Alguns autores, como Criquet et al. (2000), analisaram efeitos de outro agente estressante, o antraceno (solvente orgânico tóxico, mutagênico e cancerígeno) e dos FMAs na atividade de oxirredutases nas raízes de Medicago sativa L. e concluíram que peroxidases são espécies de enzimas dominantes na raiz e que estas enzimas podem ser estimuladas pela presença de micorrizas e/ou antraceno. A peroxidase-DAF (2,7-diaminofluorene) apresentou maior atividade em plantas micorrizadas com relação a plantas não micorrizadas. Já a peroxidase-guaiacol não 
apresentou variações de atividade significativas entre plantas micorrizadas e não micorrizadas. Mathur \& Vyas (1995) estudaram as mudanças isoenzimáticas de peroxidase em raízes de espécies de Ziziphus com Glomus fasciculatum e verificaram que a atividade desta enzima foi maior e existiu um acréscimo de duas bandas nas plantas micorrizadas em relação às não micorrizadas. Apesar destes resultados estarem relacionados com a micorrização, as repostas não condizem com os resultados obtidos neste trabalho.

Segundo Salzer et al. (1999), os mecanismos utilizados pela micorriza para amenizar situações de estresse são pouco conhecidos, mas sabe-se que estão relacionados com a expressão de várias enzimas antioxidativas. Sabe-se que FMAs modificam enzimas extracelulares e de raízes, incluindo a atividade de peroxidase. Spanu \& Bonfante-Fasolo (1988), em estudo de raízes de Allium porrum, observaram um incremento de atividade enzimática nas etapas iniciais da colonização micorrízica por Glomus versiforme. Quando a colonização micorrízica já estava estabelecida a atividade enzimática em plantas micorrizadas decresceu, tal como, no estudo de Fries et al. (1996), na interação Zea mays e Glomus intraradices. Estes resultados, portanto, são semelhantes a alguns casos no presente trabalho, no qual plantas com FMAs apresentaram menor atividade enzimática com relação aos tratamentos controles (sem micorrizas) na $2^{\mathrm{a}}$ colheita, época de maior estabelecimento micorrízico (Fig. 6). Portanto, sugere-se que a presença dos FMAs possa causar uma diminuição da atividade enzimática de peroxidase como conseqüência da amenização da toxidez de Mn nas plantas micorrizadas,embora esta resposta nem sempre tenha ficado clara no presente experimento. 


\subsubsection{Atividade de oxidase de ácido indolacético}

\subsubsection{Folha}

Considerando-se as quatro primeiras isoformas (maior peso molecular) da oxidase de AIA, na análise visual do gel com extrato foliar da $1^{\text {a }}$ colheita (Fig. 26), observou-se que as plantas do tratamento $\mathrm{CtP} 1$ apresentaram maior atividade nas doses 0 e $20 \mathrm{mg} \mathrm{kg}^{-1}$ de $\mathrm{Mn}, \mathrm{CtP} 2$ e Ge na dose $40 \mathrm{mg} \mathrm{kg}^{-1}$ de $\mathrm{Mn}$ seguida da dose $20 \mathrm{mg} \mathrm{kg}^{-1} \mathrm{de}$ Mn e $\mathrm{Gm}$ na dose $40 \mathrm{mg} \mathrm{kg}^{-1}$ de $\mathrm{Mn}$. As duas últimas isoformas (menor peso molecular) mostraram maior atividade enzimática nas doses 0 e $20 \mathrm{mg} \mathrm{kg}^{-1}$ de $\mathrm{Mn}$ do CtP1, na dose $0 \mathrm{mg} \mathrm{kg}{ }^{-1}$ de Mn do CtP2 e na dose 20 e $40 \mathrm{mg} \mathrm{kg}^{-1}$ de Mn do Gm. Nas demais doses de todos os tratamentos de inoculação a atividade foi relativamente mais baixa, não se destacando a atividade da isoforma em nenhuma dose.

Estudos para verificação do efeito dos diferentes tipos de estresse (hídrico, de nutrientes e outros) na atividade da oxidase de AIA (Bohnsak \& Albert, 1977; Mukherjee \& Coudhuri, 1981) mostraram que o aumento do estresse proporcionou o aumento da atividade de oxidase de AIA. Respostas semelhantes foram encontradas na $1^{\mathrm{a}}$ colheita, especificamente na quarta isoforma (Fig. 26), onde se observou maior atividade nas plantas do $\mathrm{CtP} 1 \mathrm{em}$ todas as doses de $\mathrm{Mn}$ e nas plantas do $\mathrm{CtP} 2$, do Ge e do Gm, na maior dose de $\mathrm{Mn}\left(40 \mathrm{mg} \mathrm{kg}^{-1}\right)$. Este resultado sugere que as plantas que estão em situação desfavorável ao desenvolvimento normal da planta, ou seja, situação de estresse, devido a menor dose de P aplicada (no caso do CtP1, Ge e Gm) e excesso de Mn, apresentaram menor crescimento (Fig. 4). Para que esta situação de estresse pudesse ser revertida, poderia ter ocorrido uma alteração metabólica na planta, apresentando uma maior produção de oxidase de AIA e de outras enzimas antioxidativas, que degradariam o hormônio de crescimento e aumentaria a atividade enzimática, tendo estas plantas mostrado menor crescimento.

$\mathrm{Na} 2^{\mathrm{a}}$ colheita, a atividade foliar da oxidase de AIA (Fig 27) das três primeiras isoformas (maior peso molecular) foi mais pronunciada nas plantas dos tratamentos CtP1 e Ge na dose $40 \mathrm{mg} \mathrm{kg}^{-1}$ de Mn e nas plantas CtP2 e Gm na dose 20 


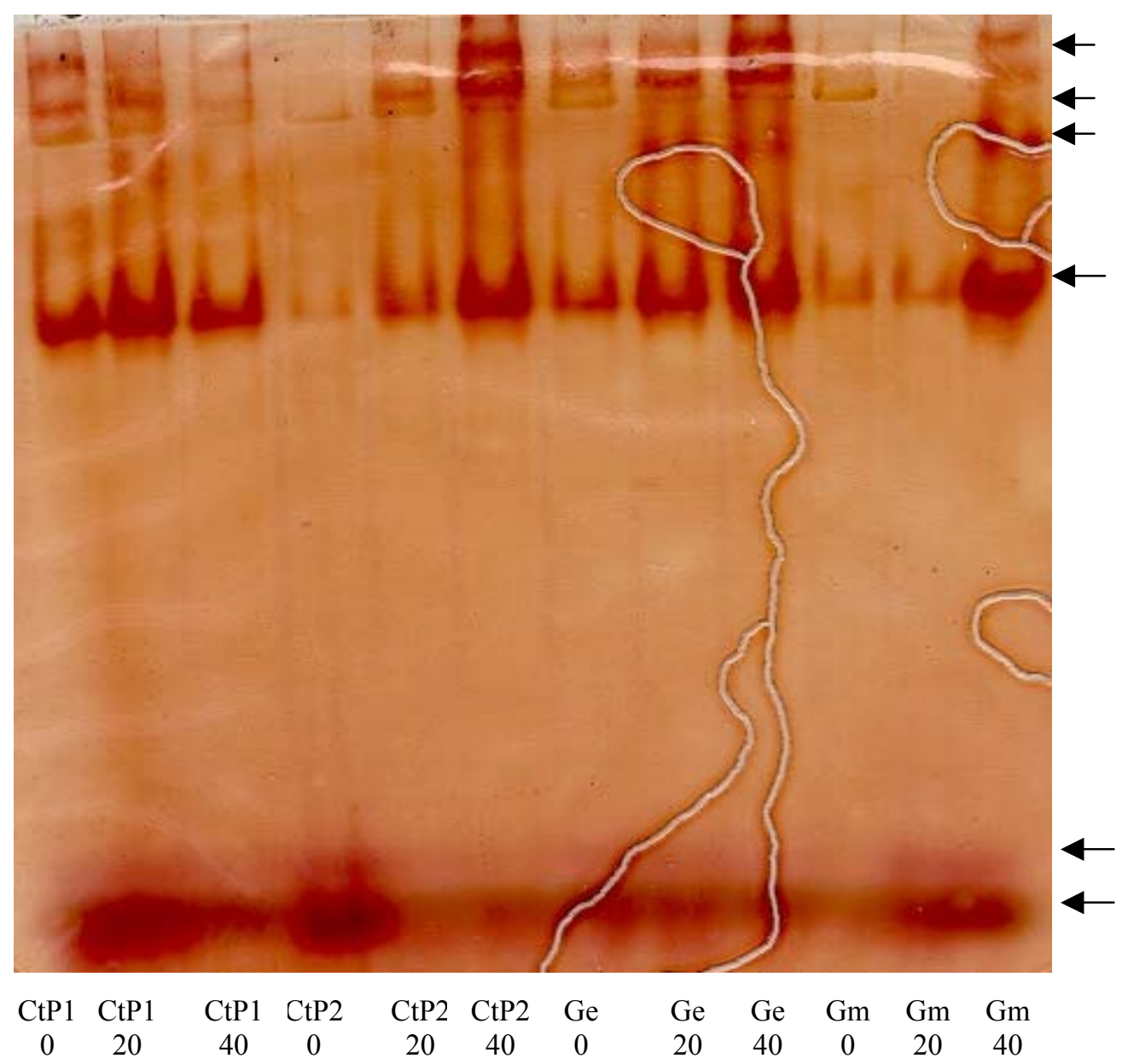

Figura 26 - Padrão eletroforético em gel de poliacrilamida para oxidase de AIA com extrato foliar de plantas de soja, que receberam duas doses de $\mathrm{P}$ (controles P1 e P2) e inoculadas com os FMAs Glomus etunicatum (Ge) e Glomus macrocarpum $(\mathrm{Gm})$ em dose P1, após 45 dias de crescimento nas doses 0 , 20 e $40 \mathrm{mg} \mathrm{kg}^{-1}$ de Mn adicionado ao substrato. As setas indicam a posição das principais isoformas. 
$\mathrm{mg} \mathrm{kg}^{-1}$ de $\mathrm{Mn}$. A quarta isoforma apresentou maior atividade nas plantas do tratamento CtP1 na dose $40 \mathrm{mg} \mathrm{kg}^{-1}$ de $\mathrm{Mn}$ e nas duas maiores doses de $\mathrm{Mn}$ (20 e $40 \mathrm{mg} \mathrm{kg}^{-1}$ ) do $\mathrm{CtP} 2$, Ge e Gm.

$\mathrm{O}$ resultado de maior atividade enzimática nas doses 20 e $40 \mathrm{mg} \mathrm{kg}^{-1}$ de $\mathrm{Mn}$ das quatro primeiras isoformas do gel da $1^{\mathrm{a}}$ e $2^{\mathrm{a}}$ colheita, verificado na maioria dos tratamentos, também é semelhante à resposta encontrada por Bohnsak \& Albert (1977) e Mukherjee \& Coudhuri (1981), que relataram que o aumento do estresse proporciona o aumento da atividade de oxidase de AIA. A comparação entre as plantas do tratamento CtP2 e Gm mostrou que as plantas micorrizadas com Gm apresentaram menor atividade enzimática que as do CtP2 (Fig. 26 e 27). Os dois tratamentos apresentaram a mesma tendência de crescimento (Fig. 4) na $2^{\mathrm{a}}$ colheita, sugerindo que ambas estejam em condições favoráveis, portanto esperava-se que teriam pelo menos a mesma resposta de atividade enzimática, mas as plantas micorrizadas apresentaram menor atividade de oxidase de AIA, portanto isto sugere que a resposta seja um reflexo da presença do FMA e que de alguma maneira amenizou a situação de toxicidade de $\mathrm{Mn}$, talvez até pela melhor nutrição da planta.

A quinta isoforma somente apareceu nas plantas do tratamento Ge na dose $20 \mathrm{mg} \mathrm{kg}^{-1}$ de Mn (Fig. 27). Nota-se resposta similar no extrato foliar da $2^{\mathrm{a}}$ colheita da enzima peroxidase (Fig. 23).

Já a última isoforma (menor peso molecular) teve um destaque grande na dose $0 \mathrm{mg} \mathrm{kg}^{-1}$ de Mn das plantas dos tratamentos CtP1, CtP2 e Gm (Fig. 27). É preciso frisar que neste gel, o extrato foliar do Ge, na dose $0 \mathrm{mg} \mathrm{kg}^{-1} \mathrm{de} \mathrm{Mn}$, não foi aplicado por falta de material disponível; possivelmente esta é a razão de não aparecer nenhuma isoforma com maior atividade neste tratamento. Este resultado parece sugerir que algumas isoformas apresentam respostas incrementadas de atividade enzimática exclusivamente em situação de ausência de Mn tóxico, mas a tendência geral ainda seria de maior atividade enzimática com excesso de Mn. 


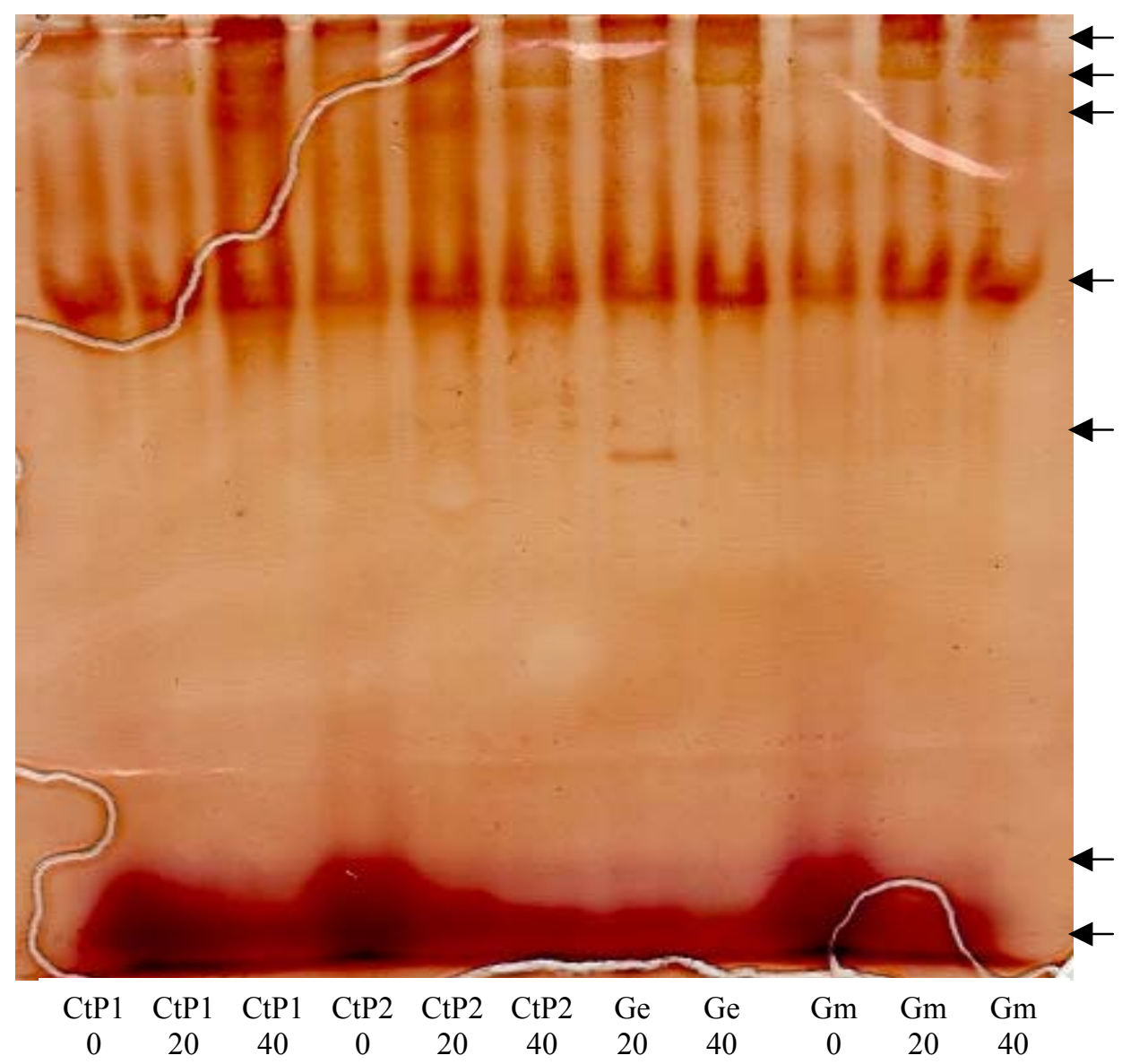

Figura 27 - Padrão eletroforético em gel de poliacrilamida para oxidase de AIA com extrato foliar de plantas de soja, que receberam duas doses de $\mathrm{P}$ (controles P1 e P2) e inoculadas com os FMAs Glomus etunicatum (Ge) e Glomus macrocarpum $(\mathrm{Gm})$ em dose P1, após 90 dias de crescimento nas doses 0, 20 e $40 \mathrm{mg} \mathrm{kg}^{-1}$ de Mn adicionado ao substrato. As setas indicam a posição das principais isoformas. 


\subsubsection{Raiz}

No extrato de raiz da $1^{\text {a }}$ colheita (Fig. 28), a análise visual do gel mostrou que a atividade da oxidase de AIA foi muito semelhante em todos os tratamentos de inoculação e entre todas as doses de Mn aplicadas no substrato. Existiu apenas uma diferença, ou seja, apresentou maior atividade enzimática nas plantas do tratamento $\mathrm{Ge}$ nas doses 20 e $40 \mathrm{mg} \mathrm{kg}^{-1}$ de Mn, mas não se tem nenhuma explicação para o ocorrido.

$\mathrm{Na} 2^{\text {a }}$ colheita (Fig. 29), as plantas do tratamento CtP1 em todas as doses de $\mathrm{Mn}$ apresentaram maior atividade enzimática. O fato do $\mathrm{CtP} 1$ apresentar maior atividade e menor crescimento (Fig. 4, $2^{\mathrm{a}}$ colheita), supõe-se estar correlacionado com a presença do menor nível de P no substrato. Este fator deve ter aumentado o nível de estresse destas plantas, aumentando a atividade de oxidase de AIA, conforme verificado, podendo ter sido mais um fator a contribuir para o pequeno crescimento destas plantas, visto que a oxidase de AIA destrói o hormônio de crescimento AIA.

Nos demais tratamentos, as plantas dos tratamentos CtP2 e Ge na dose 20

mg kg${ }^{-1}$ de $\mathrm{Mn}$ e $\mathrm{Gm}$ na dose $40 \mathrm{mg} \mathrm{kg}^{-1}$ de Mn destacaram-se também pela maior atividade (Fig. 29).

$\mathrm{Na}$ última isoforma (menor peso molecular) observou-se novamente (resultado similar ao extrato foliar da $2^{\text {a }}$ colheita, Fig. 23) que as plantas dos tratamentos CtP1, CtP2 e Ge somente na dose $0 \mathrm{mg} \mathrm{kg}^{-1}$ de Mn apresentaram maior atividade de oxidase de AIA (Fig. 29). Parece que esta isoforma nas demais doses (20 e $40 \mathrm{mg} \mathrm{kg}^{-1}$ de $\mathrm{Mn}$ ), ao invés de ter sua atividade aumentada pela presença do fator estressante $\mathrm{Mn}$, sofreu uma diminuição, induzido por este fator. Portanto a intensidade da atividade enzimática desta isoforma nos tratamentos da dose $0 \mathrm{mg} \mathrm{kg}^{-1}$ de $\mathrm{Mn}$, em especial, contraria o que foi observado para as demais isoformas (maior peso molecular).

Salvaguardando algumas pequenas discrepâncias localizadas, de maneira geral os resultados obtidos de atividade de peroxidase foi muito semelhante aos resultados de atividade da oxidase de AIA, tanto na folha quanto na raiz, concordando com os autores Klisurska \& Dencheva (1983) que, em estudos da atividade enzimática de peroxidase e oxidase de AIA em milho, mostraram que estas estão diretamente 


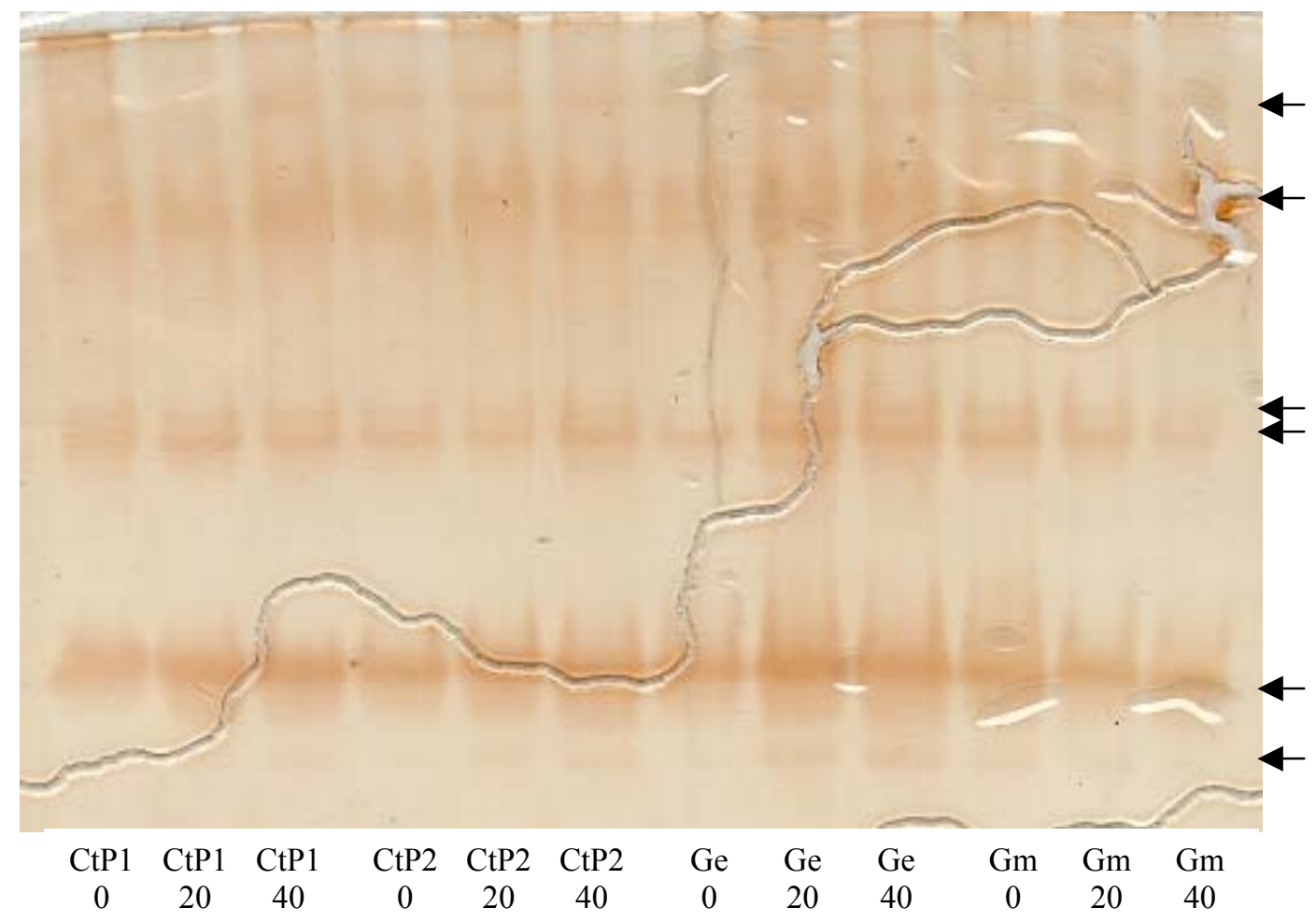

Figura 28 - Padrão eletroforético em gel de poliacrilamida para oxidase de AIA com extrato de raiz de plantas de soja, que receberam duas doses de P (controles P1 e P2) e inoculadas com os FMAs Glomus etunicatum $(\mathrm{Ge})$ e Glomus macrocarpum $(\mathrm{Gm})$ em dose P1, após 45 dias de crescimento nas doses 0, 20 e $40 \mathrm{mg} \mathrm{kg}^{-1}$ de $\mathrm{Mn}$ adicionado ao substrato. As setas indicam a posição das principais isoformas. 


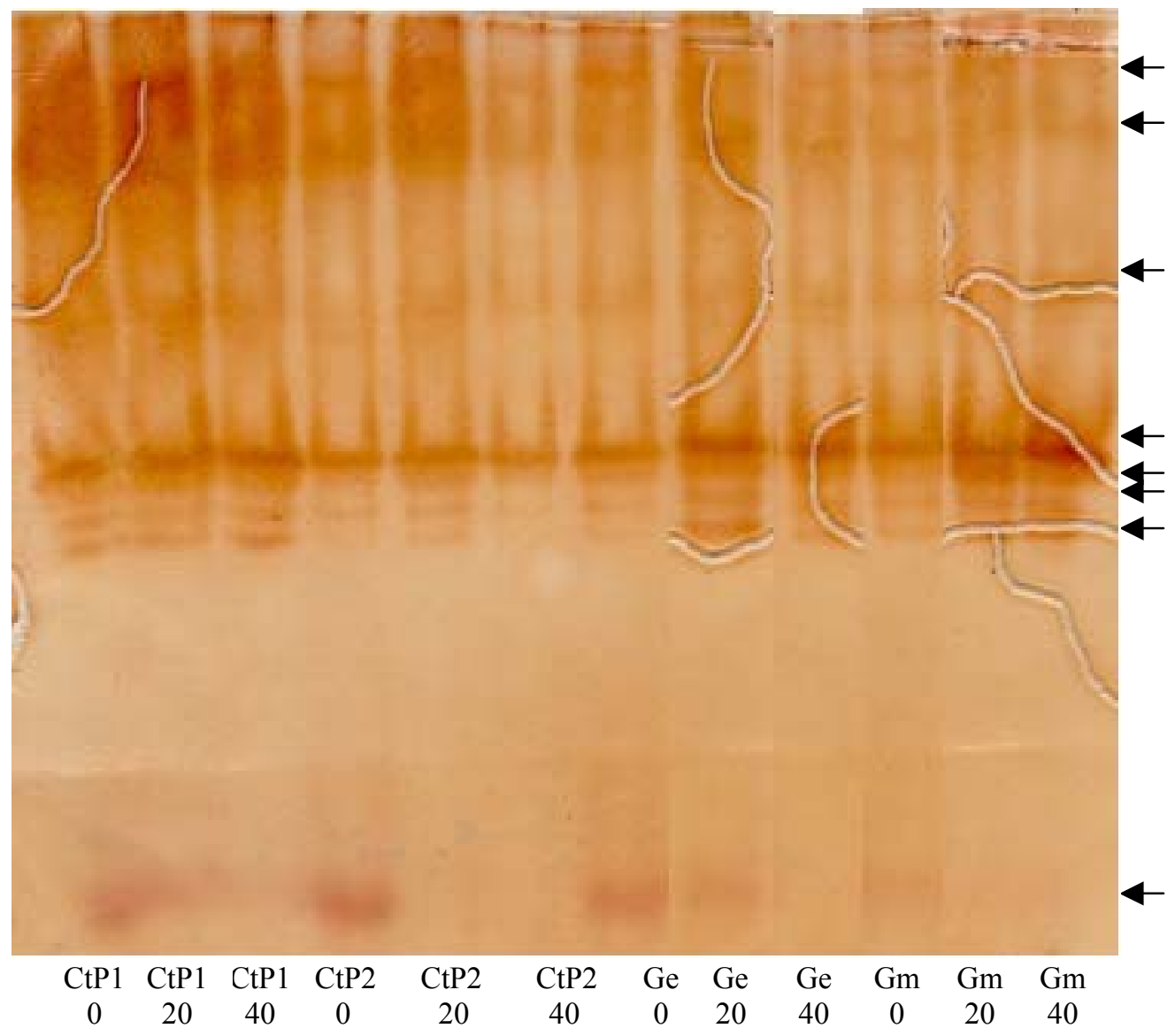

Figura 29 - Padrão eletroforético em gel de poliacrilamida para oxidase de AIA com extrato de raiz de plantas de soja, que receberam duas doses de $\mathrm{P}$ (controles P1 e P2) e inoculadas com os FMAs Glomus etunicatum (Ge) e Glomus macrocarpum $(\mathrm{Gm})$ em dose P1, após 90 dias de crescimento nas doses 0,20 e $40 \mathrm{mg} \mathrm{kg}^{-1}$ de Mn adicionado ao substrato. As setas indicam a posição das principais isoformas. 
relacionadas e que, normalmente, quando aumenta a atividade de peroxidase, aumenta também a da oxidase de AIA.

Devido esta enzima apresentar hipótese similar e semelhança dos resultados com a enzima peroxidase, não será apresentada uma discussão detalhada sobre a variação da atividade enzimática da oxidase de AIA. O que foi discutido com relação à expressão de isoformas nos diferentes tratamentos, quantidade de matéria seca total, expressão dos sintomas de toxidez de $\mathrm{Mn}$ e colonização radicular frente à expressão da atividade da peroxidase é válido também para a discussão da atividade da oxidase de AIA.

Nenhum trabalho foi encontrado que relaciona a atividade de oxidase de AIA e a micorrização de plantas.

A maioria dos trabalhos encontrados não está relacionada diretamente com toxicidade de Mn e apresenta repostas diferentes deste trabalho.

Nyguyen et al. (1993) investigaram a atividade de oxidase de AIA em raízes de abóbora e sua relação com a interação de boro e manganês e concluíram que a adição de $\mathrm{Mn}$ em raízes deficientes em boro aumentou a atividade de oxidase de AIA e que este aumento foi proporcional à concentração de Mn aplicada. Hare (1964) relata que o efeito enzimático da oxidase de AIA está relacionado com a obrigatoriedade da presença de peroxidase e $\mathrm{Mn}^{2+}$ no extrato, pois agem como cofatores na oxidação do AIA. No presente trabalho, na maioria dos casos, verificou-se que as plantas nas maiores doses de $\mathrm{Mn}$ (20 e $40 \mathrm{mg} \mathrm{kg}^{-1}$ ) apresentaram aumento de atividade de oxidase de AIA e peroxidase, mas em algumas isoformas não foram encontrados o aumento da atividade com o aumento da dose de $\mathrm{Mn}$; elas foram expressas com maior atividade em situação de ausência de Mn tóxico. Portanto, a atividade de oxidase de AIA nem todas às vezes foi proporcional à concentração de $\mathrm{Mn}$.

Trabalhos como de Morgan et al. (1976) e Coombes et al. (1976) também apresentam respostas contrárias a constatação deste trabalho, de que altos níveis de $\mathrm{Mn}$ aumentam a intensidade da enzima oxidase de AIA. Morgan et al. (1976), em ensaio com plantas de algodão em solução nutritiva, com diferentes níveis de $\mathrm{Mn}^{+2}$, verificaram que plantas inicialmente deficientes em $\mathrm{Mn}^{+2}$ apresentaram alta atividade da oxidase de 
AIA e pouco desenvolvimento. Quando trocada a solução para níveis de $\mathrm{Mn}^{+2}$ normais, as plantas recuperaram o crescimento e declinaram na atividade da oxidase de AIA. Em altas concentrações de $\mathrm{Mn}^{+2}$, as plantas sofreram severa inibição de crescimento, mas mantiveram atividade enzimática normal.

Coombes et al. (1976), ao estudaram o efeito do cobre na atividade enzimática em tecidos de raiz de cevada, verificaram que doses crescentes de $\mathrm{Cu}$ promoveram a diminuição da atividade de oxidase de AIA. Apesar deste trabalho estar relacionado com o efeito de metal pesado na atividade de oxidase de AIA (semelhante a este trabalho), parece que não é possível relacionar os diferentes íons ( $\mathrm{Cu}$ e $\mathrm{Mn}$ ), pois cada íon em cada espécie de planta apresenta um efeito diferenciado no metabolismo vegetal e, provavelmente, a presença de FMAs modifique mais ainda este efeito.

\subsubsection{Atividade de superóxido dismutase}

Os resultados obtidos no extrato foliar e de raiz foram muito semelhantes, por este motivo decidiu-se descrever os resultados da análise desses géis uma única vez.

Foi grande o número de isoformas obtidas em cada gel, sendo até difícil a indicação e contagem de todas elas, portanto, nas figuras foram indicadas somente as principais.

$\mathrm{Na} 1^{\mathrm{a}}$ colheita, tanto no extrato foliar (Fig. 30) quanto de raiz (Fig. 31), observou-se que todos os tratamentos em todas as doses de Mn apresentaram atividade de superóxido dismutase (SOD) muito semelhante. Em alguns casos apenas, verificou-se atividade enzimática incrementada nas plantas do tratamento CtP1 e Ge na dose $20 \mathrm{mg}$

$\mathrm{kg}^{-1}$ de Mn, na folha e, nas plantas do tratamento CtP1 e Ge, na dose $0 \mathrm{mg} \mathrm{kg}^{-1} \mathrm{de} \mathrm{Mn}$, na raiz. Não se encontraram explicações plausíveis para estas observações.

$\mathrm{Na} 2^{\mathrm{a}}$ colheita, tanto no extrato foliar (Fig. 32) quanto de raiz (Fig. 33), observou-se uma diferença nítida de atividade enzimática entres as plantas inoculadas com FMAs e as não inoculadas. Os tratamentos com FMAs em todas as doses de Mn apresentaram aumento do número de isoformas, que os tratamentos não inoculados. No 


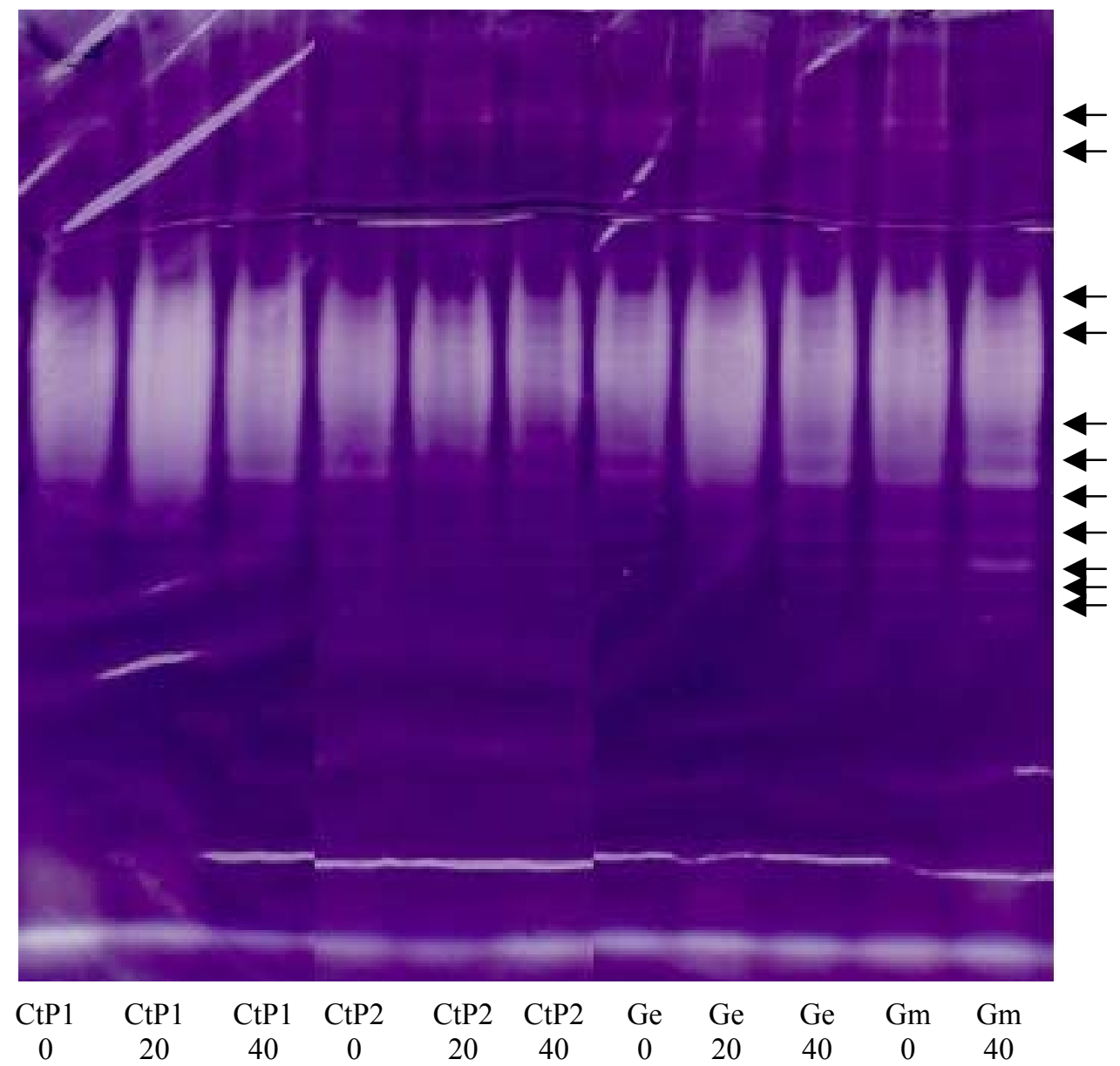

Figura 30 - Padrão eletroforético em gel de poliacrilamida para superóxido dismutase com extrato foliar de plantas de soja, que receberam duas doses de $\mathrm{P}$ (controles P1 e P2) e inoculadas com os FMAs Glomus etunicatum (Ge) e Glomus macrocarpum $(\mathrm{Gm})$ em dose P1, após 45 dias de crescimento nas doses 0, 20 e $40 \mathrm{mg} \mathrm{kg}^{-1}$ de Mn adicionado ao substrato. As setas indicam a posição das principais isoformas. 


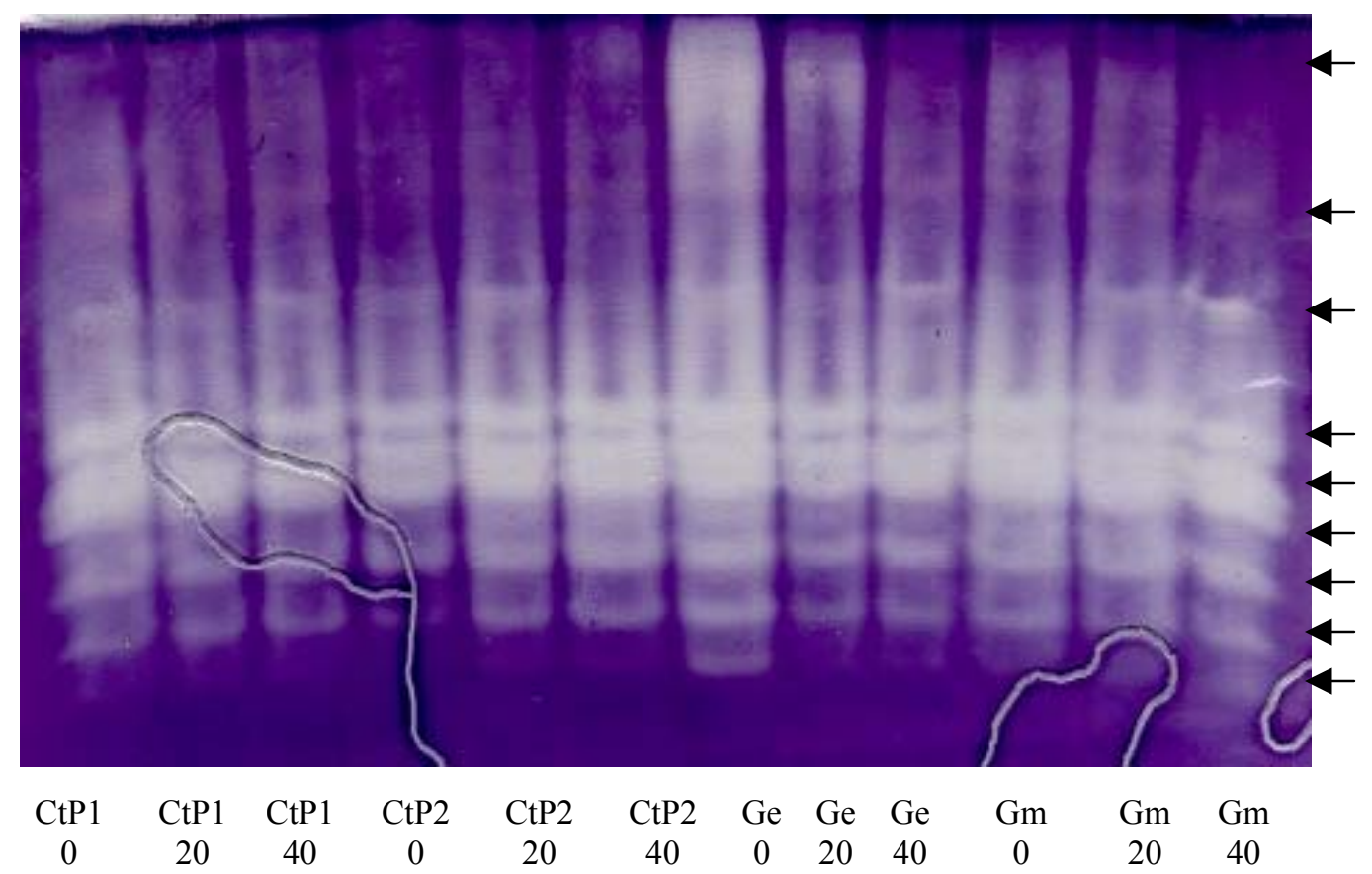

Figura 31 - Padrão eletroforético em gel de poliacrilamida para superóxido dismutase com extrato de raiz de plantas de soja, que receberam duas doses de $\mathrm{P}$ (controles P1 e P2) e inoculadas com os FMAs Glomus etunicatum $(\mathrm{Ge})$ e Glomus macrocarpum (Gm) em dose P1, após 45 dias de crescimento nas doses 0,20 e $40 \mathrm{mg} \mathrm{kg}^{-1}$ de $\mathrm{Mn}$ adicionado ao substrato. As setas indicam a posição das principais isoformas. 


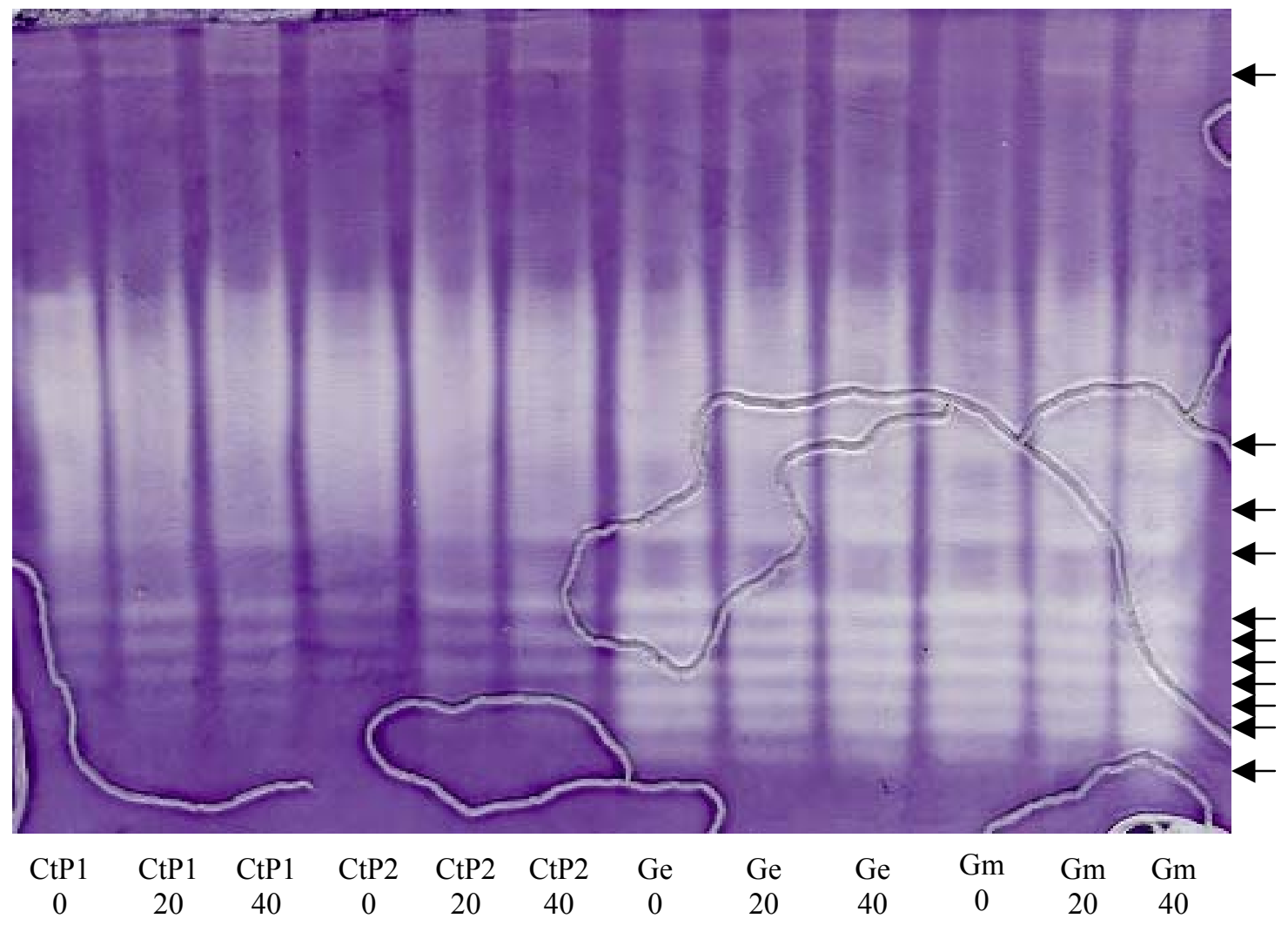

Figura 32 - Padrão eletroforético em gel de poliacrilamida para superóxido dismutase com extrato foliar de plantas de soja, que receberam duas doses de $\mathrm{P}$ (controles P1 e P2) e inoculadas com os FMAs Glomus etunicatum (Ge) e Glomus macrocarpum $(\mathrm{Gm})$ em dose P1, após 90 dias de crescimento nas doses 0,20 e $40 \mathrm{mg} \mathrm{kg}^{-1}$ de Mn adicionado ao substrato. As setas indicam a posição das principais isoformas. 


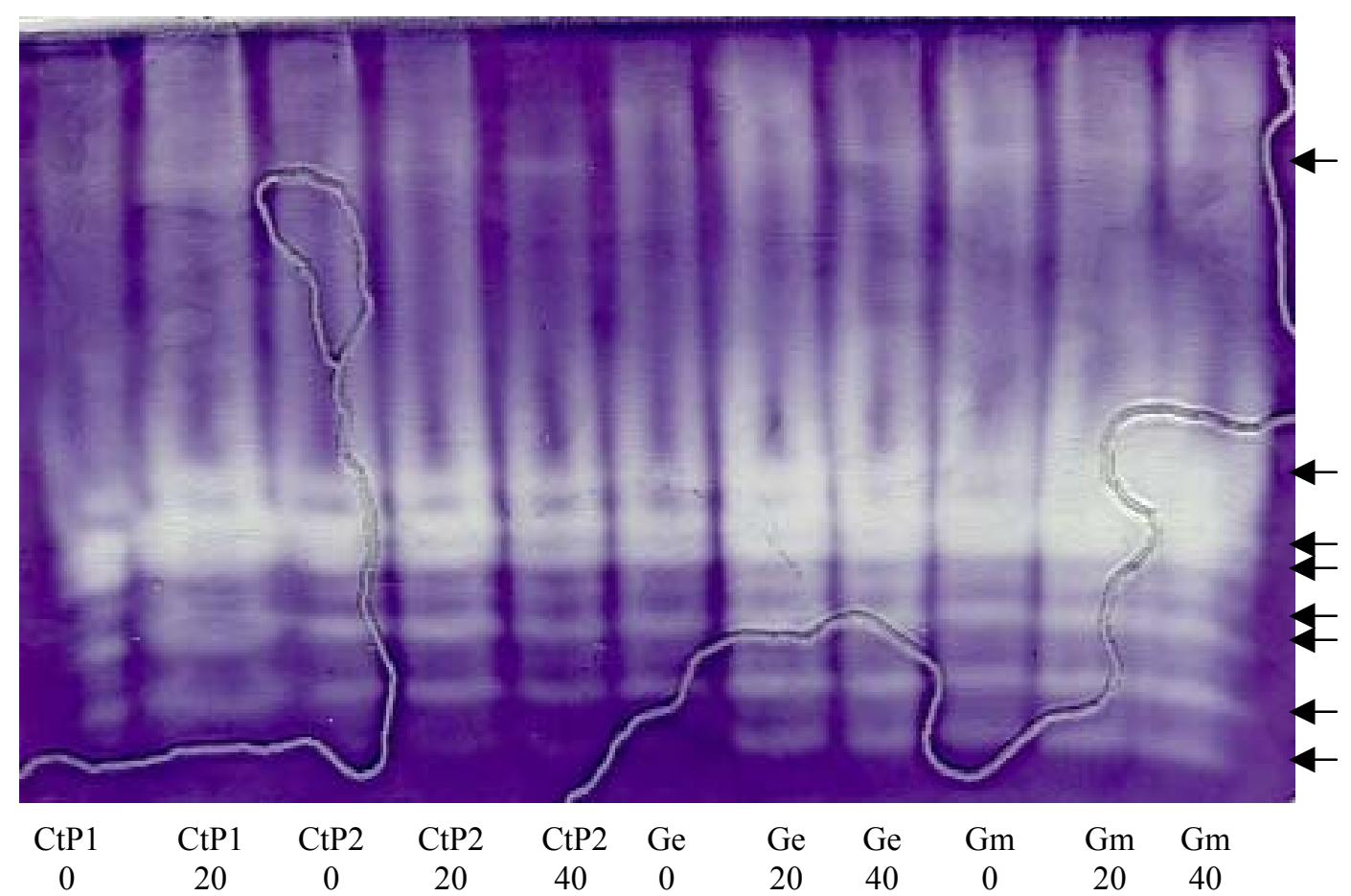

Figura 33 - Padrão eletroforético em gel de poliacrilamida para superóxido dismutase com extrato de raiz de plantas de soja, que receberam duas doses de $\mathrm{P}$ (controles P1 e P2) e inoculadas com os FMAs Glomus etunicatum (Ge) e Glomus macrocarpum (Gm) em dose P1, após 90 dias de crescimento nas doses 0, 20 e $40 \mathrm{mg} \mathrm{kg}^{-1}$ de Mn adicionado ao substrato. As setas indicam a posição das principais isoformas. 
extrato foliar todos os tratamentos com FMAs em todas as doses de Mn apresentaram maior atividade de SOD, já no extrato de raiz apenas as planta inoculadas com FMAs (Ge e $\mathrm{Gm}$ ), na dose $0 \mathrm{mg} \mathrm{kg}^{-1}$ de $\mathrm{Mn}$ não apresentaram maior atividade de SOD.

Estes resultados de atividade enzimática nos tratamentos inoculados com FMAs e não inoculados, na $1^{\mathrm{a}}$ e $2^{\mathrm{a}}$ colheita, foram os mesmos esperados quando se faz uma correlação com a colonização radicular. $\mathrm{Na} 1^{\mathrm{a}}$ colheita a colonização micorrízica não esta estabelecida totalmente ou ainda sofreu severa inibição devido ao aumento das doses de Mn (Fig. 7), portanto as plantas inoculadas e não inoculadas apresentaram atividade enzimática semelhante. Já na $2^{\mathrm{a}}$ colheita o fato da colonização micorrízica na planta de soja já estar estabelecida (Fig. 7), possibilitou a melhor condição (maior absorção de P) da planta e, como resposta, as plantas micorrizadas apresentaram maior atividade de SOD que as plantas não micorrizadas.

Estes resultados sugerem que a maior atividade de SOD e o aparecimento de novas isoformas sejam inerentes à condição de planta micorrizada. Se de fato há uma correlação positiva entre a presença do endófito e a maior atividade enzimática, este fato poderia auxiliar na explicação do porquê de plantas micorrizadas mostrarem menor toxidez de Mn, pois esta atividade aumentada da enzima levaria a uma diminuição do estresse vegetal.

Da mesma maneira, Arines et al. (1994), estudando o sistema simbiótico de Pisum sativum e Glomus mosseae, avaliaram os padrões eletroforéticos e atividades de SODs em raízes micorrizadas e não micorrizadas, e os resultados mostraram que isoformas de SOD eram expressas preferencialmente em raízes micorrizadas. Palma et al. (1993) observaram, em simbioses de Trifolium pratense com Glomus mosseae, que certas isoenzimas de SOD são induzidas pelo FMA, o que concorda plenamente com as observações do presente trabalho.

Concordando ainda com os resultado acima detalhados, Ruiz-Lozano et al. (1996), em estudos da atividade de SOD em plantas de alface (Lactuca sativa) sujeitas a estresse hídrico e colonizadas com Glomus mosseae e G. deserticola verificaram maior atividade específica nas plantas micorrizadas do que nos controles não micorrizados. Concluíram que a indução de SOD em plantas micorrizadas estaria 
relacionada aos mecanismos de interação entre FMAs e a planta, em resposta ao estresse hídrico.

Neste trabalho não existiu evidência no extrato foliar que a dose de $\mathrm{Mn}$ no substrato tenha influenciado o padrão eletroforético de cada tratamento, portanto parece que o aumento da dose de Mn não está relacionado com a atividade de SOD, ou também, a influência do fator estressante Mn não alterou a atividade de SOD, fato que concorda com os resultados obtidos por Ferreira et al. (2002) que, apesar de terem utilizado o metal $\mathrm{Cd}$, verificaram que a resposta de atividade das enzimas antioxidativas SOD e CAT de plantas de soja não apresentaram variação significativa em resposta ao estresse de $\mathrm{Cd}$, tanto em raiz quanto na folha.

Outros autores (Foster \& Hess, 1980) quando estudaram a resposta da atividade de SOD e glutationa redutase em tecido foliar de plantas de algodão, constataram que a atividade da SOD foi maior em condições normais de $\mathrm{O}_{2}(21 \%)$ do que em situações de excesso de $\mathrm{O}_{2}(75 \%)$. Portanto, também relataram que o aumento da atividade desta enzima parece não estar correlacionado com a indução de estresses fisiológicos de naturezas variadas. Embora Willekens et al. (1995) tenham relatado que grande variedade de estresses oxidativos altera o padrão de atividade de SOD, os resultados do presente trabalho são os mesmos obtidos por Foster \& Hess (1980).

Contrariando os resultados obtidos neste trabalho em discussão, aumentos de atividade de SOD foram encontrados em resposta a estresse de Fe (Hendry \& Brocklebank, 1985) e ozônio (Tanaka et al., 1985; Azevedo et al., 1998). Ainda, a atividade de SOD foi aumentada em folhas de ervilha sob ação do herbicida paraquat (Donahue et al., 1997) e diminuída em folhas de milho sob alagamento (Yan et al., 1996). Estes últimos trabalhos parecem indicar que, em alguns casos, a SOD também pode ser ativada por fatores estressantes, o que não ocorreu com relação ao $\mathrm{Mn}$, conforme visto acima.

A alteração no padrão de atividade de SOD é bastante variada e muitas vezes dependente da espécie de planta, tecido, isoenzima e etapa de desenvolvimento da espécie (Azevedo et al., 1998). Deve-se acrescentar nessa lista que a atividade de SOD é 
dependente principalmente da micorrização ou não da planta, conforme discutido anteriormente.

\subsubsection{Atividade de catalase}

Foram muitas as dificuldades encontradas para revelação da enzima catalase. As revelações dos géis ficaram de difícil visualização para constatar diferenças de intensidade de bandas e conseqüente análise da atividade enzimática.

Algumas amostras foram analisadas, mas não se conseguiu uma repetibilidade, pois nem todas as vezes conseguiu-se uma revelação adequada da enzima no gel de poliacrilamida. Portanto, os resultados não foram confiáveis e por isto preferiu-se não apresentar nem discutir os resultados obtidos.

As poucas respostas conseguidas mostraram que, nos géis com extrato foliar, existiram bandas de coloração verde escuro em todos os tratamentos. Ferreira et al. (2002) também observou esse tipo de bandas em seus géis e estas bandas foram identificadas como sendo um complexo de proteínas do sistema antena coletora de luz, associado ao fotossistema II.

Ruiz (1998), no estudo da catalase, com baixas e altas doses de P, em plantas de feijão micorrizadas e não micorrizadas, mostrou que raízes colonizadas com Glomus clarum apresentaram alterações significativas de aumento de atividade da catalase em relação aos controles não inoculados.

Segundo Rice-Evans et al. (1991), as reações de catalase tornam-se mais importantes quando a concentração de $\mathrm{H}_{2} \mathrm{O}_{2}$ é mais alta pois, em concentração normal de $\mathrm{H}_{2} \mathrm{O}_{2}$, este é reduzido pela glutationa redutase e peroxidase. Talvez a dificuldade em demonstrar a presença da catalase e sua atividade esteja relacionada com a quantidade de $\mathrm{H}_{2} \mathrm{O}_{2}$ formada, quer porque a quantidade não foi suficiente para a enzima catalase agir, quer porque a $\mathrm{H}_{2} \mathrm{O}_{2}$ foi degrada pela peroxidase e outras enzimas. 


\section{CONCLUSÕES}

- Níveis de Mn que variam de 10 a $40 \mathrm{mg} \mathrm{kg}^{-1}$ de $\mathrm{Mn}$ no substrato podem induzir respostas de toxidez de Mn em plantas de soja, acompanhadas de redução de crescimento e alterações no padrão de absorção de vários nutrientes vegetais;

- O aumento da dose de $\mathrm{P}$ e a presença da micorriza são fatores de atenuação da toxidez de Mn em soja;

- Durante a fase de colonização radicular (superior a 45 dias), antes da síntese efetiva da micorriza funcional, as plantas de soja inoculadas com FMAs apresentam-se mais estressadas do que as plantas controles, possivelmente pelo grande dreno de carbono imposto. No fim do ciclo (90 dias ou mais), as plantas de soja com micorriza funcional mostram-se mais vigorosas e menor estressadas do que as plantas controles e contém maior concentração de fósforo nos tecidos aéreos;

- Plantas de soja micorrizadas e submetidas a níveis crescentes de Mn contêm menor concentração de Mn em seus tecidos do que as plantas controle;

- A atividade de oxidase de AIA é semelhante à atividade de peroxidase e, na maioria das isoformas em soja, a atividade aumenta com o aumento da toxidez de Mn na planta, ocorrendo correlação positiva entre o incremento de ambas. Algumas isoformas das enzimas oxidase de AIA e peroxidase, entretanto, apresentam sua atividade diminuída com o aumento das doses de Mn.

- A presença do FMA na planta de soja freqüentemente diminui a atividade enzimática de peroxidase e oxidase de AIA principalmente no caso das plantas inoculadas com Glomus macrocarpum; 
- A maior atividade e o maior número de isoformas de superóxido dismutase estão relacionados com a presença de FMAs na parte aérea de plantas de soja e não com o aumento dos níveis de Mn. Portanto, essa enzima não pode ser utilizada para medir o nível de estresse causado por altas doses de Mn, mas seria útil para detectar o nível de micorrização em plantas de soja antes da sua colheita;

- Apesar da peroxidase e da superóxido dismutase serem ambas consideradas enzimas antioxidativas, a sua expressão em plantas de soja micorrizadas e submetidas a níveis de Mn apresentam-se de maneira diferenciada;

- A atividade de catalase nem sempre pôde se comprovada em plantas de soja micorrizada ou não sob níveis crescentes de Mn. 


\section{REFERÊNCIAS BIBLIOGRÁFICAS}

ADAMS, F. Crop responses to lime in the southern United States. In: ADAMS, F. (Ed.). Soil acidity and liming. 2.ed. Madison: American Society of Agronomy, 1984. p.246-259. (Agronomy 12)

ALFENAS, A.C.; PETERS, I.; BRUNE, W.; PASSADOR, G.C. Eletroforese de proteínas e isoenzimas de fungos e essências florestais. Viçosa: Universidade Federal de Viçosa, 1991.

ALFENAS, A.C. Eletroforese de isoenzimas e proteínas afins: fundamentos e aplicações em plantas e microrganismos. Viçosa: Universidade Federal de Viçosa, 1998. 574p.

ALLAN, D. L.; JARREL, W.M. Proton and copper adsorption to maiza and soybean root cell walls. Plant Physiology, v.89, p.823-832, 1989.

ARINES, J.; QUINTELA, M.; VILARIÑO, A.; PALMA, J.M. Protein patterns and superoxide dismutase activity in non-mycorrhizal, and arbuscular mycorrizal Pisum sativum plants. Plant and Soil, v.166, n.1, p.37-45, 1994.

ASADA, K. The water-water cycle in chloroplasts: scavenging of active oxygens and dissipation of excess photons. Annual Review of Plant Physiology and Plant Molecular Biology, v.50, p.601-639, 1999. 
ATKINSON, D.E. Regulation of enzyme activity. Annual Review of Biochemistry, v.35, p.85-124, 1966.

AZEVEDO, R.A.; ALAS, R.M.; SMITH, R.J.; LEA, P.J. Response of antioxidant enzymes to transfer from elevated carbon dioxide to air and ozone fumigation, in leaves and roots of wild-type and catalase-deficiente mutant of barley. Physiologia Plantarum, v.104, p.280-292, 1998.

BALESTRASSE, K.B.; GARDEY, L.; GALLEGO, S.M.; TOMARO, M.L. Response of antioxidant defence system in soybean nodules and roots subjected to cadimium stress. Australian Journal of Plant Physiology, v.28, p.497-504, 2001.

BEAUCHAMP, C.H.; FRIDOVICH, I. Superoxide dismutase: improved assays and an assay applicable to acrylamide gels. Analytical Biochemistry, v.44, p.276-287, 1971.

BECANA, M.; MORAN, J, F.; ITURBE-ORMAETXE, I. Iron-dependente oxygen free radical generation in plants subjected to enviromental stress: toxicity and antioxidant protection. Plant and Soil, v.201, p.137-147, 1998.

BENES, K.; SEIDLOVÁ, F. A suitable method for localization of IAA-oxidase. Biologia Plantarum, v.20, n.1, p.64-66, 1978.

BENTIVENGA, G.; BONINI, C.; D’AURIA, M.; DE BONA, A.; MAURIELLO, G. Singlet oxygen mediated degradation of klason lignin. Chemosphere, v.39, n.14, p.2409-2417, 1999.

BERGMEYER, H.U.; GAWEHN, K.; GRASSL, M. Enzymes as biochemical reagents. In: BERGMEYER, H.U. (Ed.). Methods of enzymatic analysis. 2.ed. New York: Academic Press, 1974. p.493-495. 
BIERMANN, B.J.; LINDERMAN, R.G. Increased germination and growth using preplant inoculation with a mycorrhizal fungus. Journal of American Society and Horticulture Science, v.108, p.972-976, 1983.

BOHNSACK, C.W.; ALBERT, L.S. Early effects of boron deficiency on indoleacetic acid oxidase levels of squash root tips. Plant Physiology, v.59, p.1047-1050, 1977.

BONFANTE-FASOLO, P. Anatomy and morfology of VA mycorrhizae. In: POWEL, C.L; BAGYARAJ, D.J. (Ed.). VA mycorrhiza. Boca Raton: CRC Press, 1984. $234 p$.

BOWEN, H.J.M. Trace elements in Biochemistry. London: Academic Press, 1966. $241 \mathrm{p}$.

BOWLER, C.; VAN MONTAGU, M.; INZÉ, D. Superoxide-dismutase and stress tolerance. Annual Review of Plant Physiology and Plant Molecular Biology, v.43, p.83-116, 1992.

BRADFORD, M. M. A rapid and sensitive method for the quantification of microgram quantities of proteins utilizing the principle of protein-dye binding. Analytical Biochemistry, v.72, p.248-254, 1976.

BURDON, J.J.; MARSHALL, D.R. The use of isozymes research. In: TANKSLEY, S. D.; ORTON, T.J. (Ed.). Isosymes in plants genetics and breeding: part A. Amsterdam: Elsevier, 1983. p.401-412.

BUWALDA, J.G.; GOH, K.M. Host-fungus competition for carbon as the cause of growth depressions in vesicular-arbuscular mycorrhizal ryegrass. Soil Biology and Biochemistry, v.14, p.103-106, 1982. 
CAKMAK, I.; HORST, W.J. Effect of alluminium on lipid peroxidation, superoxide dismutase, catalase and peroxidase activies in roots tips of soybean (Glycine max). Physiologia Plantarum, v.83, n.3, p.463-468, 1991.

CÂMARA, G.M.S. Soja: tecnologia da produção. Piracicaba: USP/ESALQ, 1998. 293p.

CAMARGO, C.E.O. Tolerances of wheat cultivars to different levels of manganese in nutrient solitions: evidence of genetic control. In: GRAHAM, D; HANNAM, R.J.; UREN, N.C. (Ed.). Manganese in soils and plants. Boston: Kluwer Academic Press, 1988. p.109-112.

CARDOSO, E.J.B.N. Efeito de micorriza vesículo-arbusculares e fosfato na simbiose soja- Rhizobium. Revista Brasileira de Ciência do Solo, v.9, p.125-130, 1985.

CARDOSO, E.J.B.N. Eficiência de fungos micorrízicos vesículo-arbusculares em soja com Rhizobium japonicum e fosfato de rocha, em função do tipo de solo. Revista Brasileira de Ciência do Solo, v.10, p.17-23, 1986.

CARDOSO, E.J.B.N. Interaction of micorrhiza, phosphate and manganese in soybean. In: EUROPEAN SYMPOSIUM ON MYCORRHIZAS, 4., Granada, 1994. Mycorrhizas in integrated systems from genes to plant development. Anais. Granada, 1996a. p.304-306.

CARDOSO, E.J.B.N. Micorriza em soja como protetor à toxidez de manganês. In: CONGRESSO LATINO-AMERICANO DE CIÊNCIA DO SOLO, 13., Águas de Lindóia. Anais. Piracicaba: Sociedade Brasileira de Ciência do Solo, 1996b. 6p.

CARLSON, J.B. Morphology. In: CALDWELL, B.E. (Ed.). Soybean: production, improvement and uses. Madison: American Society of Agronomy, 1973. p.17-95. 
COOMBES, A.J.; LEPP, N.W.; PHIPPS, D.A. The effect of copper on IAA-oxidase activity in root tissue of barley (Hordeum vulgare. C.v. Zephyr). Zeitschrift für Pflanzenphysiologie, v.80, p.236-242, 1976.

CRIQUET, S.; JONER, E.; LEGLIZE, P. LEYVAL, C. Anthracene and mycorrhiza affect the activity of oxidoresuctases in the roots and rizosphere of lucerne (Medicago sativa L.). Biotechnology Letters, v.22, p.1733-1737, 2000.

DONAHUE, J.L.; OKPODU, C.M.; CRAMER, C.L.; GRABAU, E.A.; ALSCHER, R.G. Responses of antioxidants to paraquat in pea leaves. Plant Physiology, v.13, p.249-257, 1997.

ELSTNER, E.F.; OSSWALD, W. Mechanisms of oxgen activation dur g plant stress. In: CRAWOFORD, R.M.M.; HENDRY, G.A.F.; GOODMAN, B.A. (Ed.). Oxygen and enviromental stress in plants. Edinburgh: Royal Society of Edinburgh, 1994. p.131-154. (Biological Sciences)

EMPRESA BRASILEIRA DE PESQUISA AGROPECUÁRIA. Recomendações técnicas para a cultura da soja na região central do Brasil 1999/2000. Londrina: Embrapa, 1999. 226p.

FERREIRA, R.R.; FORNAZIER, R.F.; VITÓRIA, A.P.; LEA P.J.; AZEVEDO, R.A. Changes in antioxidant enzyme activities in soybean under Cd stress. Journal of Plant Nutrition, v.25, n.2, p.327-342, 2002.

FOSTER, J.G.; HESS, J.L. Responses of superoxide dismutase and glutathione reductase activities in cotton leaf tissue exposed to an atmosphere enriched in oxygen. Plant Physiology, v.66, p.482-487, 1980. 
FOY, C. D.; CHANEY, R. L.; WHITE, M. C. The physiology of metal toxicity in plants. Annual Review of Plant Physiology, v.29, p.511-568, 1978.

FOY, C. D. Physiological effects of hydrogen, aluminium and manganese toxicities in acid soils. In: ADAMS, F. (Ed.). Soil acidity and liming. 2.ed. Madison: American Society of Agronomy, 1984. p.57-97. (Agronomy 12)

FOYER, C.H.; LELANDAIS, M. KUNERT, K.J. Photooxidative stress in plants. Physiologia Plantarum, v.92, p.696-717, 1994.

FRIC, F. Oxidative enzymes. In: HEITEFUSS, R.; WILLIAMS, P.H. (Ed.). Physiological plant pathology. New York: Springer-Verlag, 1976. p.617-631.

FRIDOVICH, I. Superoxide dismutase. Advances in Enzymology and related areas of Molecular Biology, v.58, p.61-76, 1986.

FRIES, L.M.M.; PACOVSKY, R.S.; SAFIR, G.R. Expression of isozymes altered by both Glomus intraradices colonization and forminetion application in corn (Zea mays L.) roots. Soil Biology and Biochemistry, v.28, p.981-988, 1996.

FRUGOLI, J.A.; ZHONG, H.H.; NUCCIO, M.L.; McCOURT, P.; McPEEK, M.A.; THOMAS, T.L.; McCLUNG, C.R. Catalase is encoded by a multigene family in Arabidopsis thaliana (L.) Heynh. Plant Physiology, v.112, p.327-336, 1996.

FRY, S.C. Cross-linking of matrix polymers in growing cell wall of angiosperms. Annual Review of Plant Physiology, v.37, p.165-186, 1986.

GASPAR, T.; PENEL, C.; CASTILLO, J. F. ; GREPPIN, H. A two-step control of basic and acidic peroxidases and its significance for growth and development. Physiologia Plantarum, v.64, p.418-423, 1985. 
GERDEMANN, J.W.; NICOLSON, T, H. Espores of mycorrhizal Endogone species extracted from soil by wet sieving and decanting. Transactions of British Mycological Society, v.46, n.2, p.235-244, 1963.

GILMORE, A.E. The influence of endotrophic mycorrhizae on growth of peech seedling. Journal of American Society and Horticulture Science, v.96, p.263-268, 1971.

GIOVANNETTI, M.; MOSSE, B. An evaluation of techniques for measuring vesiculararbuscular mycorrhizal infection in roots. New Phytology, v.91, p.183-189, 1980.

GODO, G.H.; REISENAUER, H. M. Plant effects on soil manganese avaiability. Soil Science Society of American Journal (Madison), n.44, p.993-995, 1980.

GOGORCENA, Y.; ITURB-ORMAETXE, I.; ESCUDERO, P.R.; BECANA, M. Antioxidant defenses against activated oxygen in pea nodules subjected to water stress. Plant Physiology, v.108, n.2, p.753-759, 1995.

GOLDBERG, R.; LÊ, T.; CATESSON, A.M. Localization and proprieties of cell wall enzyme activities related to the final stages of lignin biosynthesis. Journal of Experimental Botany, v.36, p.503-510, 1985.

GONZÁLEZ, A.; STEFFEN, K.L.; LYNCH, J.P. Ligth and excess manganese: implications for oxidative stress in common bean. Plant Physiology, v.118, n.493$504,1998$. 
GOODMAN, B.A. The involvement of $\mathrm{O}_{2}$-derives free radical in plant-pathogen interactions. In: CRAWOFORD, R.M.M.; HENDRY, G.A.F.; GOODMAN, B.A. (Ed.). Oxygen and environmental stress in plants. Edinburgh: Royal Society of Edinburgh, 1994. p.155-165. (Biological Sciences)

GORDON, S. A.; WEBER, R.P. Colorimetric estimation of indolacetic acid. Plant Physiology, v.26, p.192-195, 1951.

GORTNER, W.A.; KENT, M. Indoleacetic acid oxidase and an inhibitor in pineapple tissue. Journal of Biology and Chemistry, v.204, p.593-603, 1953.

GRAHAM, J.H.; SYLVERTSEN, J.P. Host determinants of mycorrhizal dependency of citrus rootstock seedlings. New Phytology, v.91, p.183-189, 1985.

HAARD, N.F.; MARSHAL, M. Isoperoxidase changes in soluble and particule fractions of sweet potato root resulting from cut injury, ethylene and black rot infection. Physiological Plant Pathology, v.8, p.195-205, 1976.

HARE, R.C. Indoleacetic acid oxidase. The Botanical Review, v.30, p.129-165, 1964.

HAVIR, E.A.; McHALE, N.A. Regulation of catalase activity in leaves of Nicotiana sylvestris by high $\mathrm{CO}_{2}$. Plant Physiology, v.89, p.952-957, 1989.

HENDRY, A. F.; BROCKLEBANK, K.J. Iron-induced oxygen radical metabolism in waterlogged plants. New Phytopatology, v.101, p.199-206, 1985.

HEWITT, E.J.; NICHOLAS, D.J.D. Metabolic inhibitors. In: HOCHSTER, R.M.; UASTEL, J.H. (Ed.). Metabolic inhibitors a comprehensive treatise. New York: Academic Press, 1963. v.1. 
HEYLAR, K.R. Effects of aluminium and manganese toxicity on legume growth. In: ANDREW, C.S.; KAMPRATH, E.J. (Ed.). Mineral nutrition of legumes in tropical and subtropical soils. East Melbourne: Commonwealth Scientific and Industrial Research Organization, 1978. p.207-231.

HOAGLAND, R. E. Biochemical responses of plants to pathogenns. In: HOAGLAND, R.E. (Ed.). Microbes and microbial products as herbicides. Washington: Americal Chemical Society, 1990. p.87-113.

HORST, W.J. The physiology of manganese toxicity. In: GRAHAM, R.D.; HANNAHAM, R.J.; UREN, N.C. (Ed.). Maganese in soils and plants. Boston: Kluver Academic Press, 1988. p.175-188.

KENEDY, C.W; JONES, J. E. Evaluation quantitative screening methods for manganese toxicity in cotton genotypes. Journal of Plant Nutrition, v.14, p.1331-1339, 1991.

KIANG, Y.T.; GORMAN, M.B. Soybean. In: TANKSLEY, S.D.; ORTON, T.J. (Ed.). Isozymes in plants genetics and breeding: part B. Amsterdam: Elsevier, 1983. p.295-328.

KLISURSKA, D.; DENCHEVA, A. Peroxidase and IAA-oxidase in crude and partially purified enzyme extracts of growing and differentiating root cells. Biologia Plantarum (Praha), v.25, n.2, p.110-116, 1983.

KOTHARI, S.K.; MARSCHNER, H.; RÖMHELD, V. Effect of vesicular-arbuscular mycorrhizal fungus and rhizosphere microorganisms on manganese reduction in the rhizosphere and manganese concentrations in maize (Zea mays L.). New Phytology, v.117, p.649-655, 1990. 
KUCEY, R.M.N.; JANZEN, H.H. Effects of VAM and reduced nutrient availability on growth and phosphorus and micronutrient uptake of wheat na field beans under greenhouse conditions. Plant and Soil, v.104, p.71-78, 1987.

LAGRIFFOUL, A.; MOCQUOT, B.; VANGRONSVELD, J.; MENCH, M. Cadmium toxicity effects on growth, mineral and chlorophyll contents, and activities of stress related enzymes in young maize plants (Zea mays L.). Plant and Soil, v.200, p.241$250,1998$.

LAMBAIS, M.R.; MEHDY, M.C. Suspression of endochitinase, $\beta$-1,3-glucanase and chalone isomerase expression in bean vesicular-arbuscurlar mycorrhizal roots under different soil phosphate conditions. Molecular Plant-Microbe Interactions, v.6, n.1, p.75-83, 1993.

LAMBAIS, M.R.; MEHDY, M.C. Spatial distribution of chitinases and $\beta$-1,3-glucanase transcripts in bean vesicular-arbuscurlar mycorrhizal roots under low and high soil phosphate conditions. The New Phytologist, v.140, n.1, p.33-42, 1998.

LEIDI, E.O.; GOMEZ, M.; DE LA GUARDIA, M.D. Soybean genetic differences in response to Fe and Mn: activity of metalloenzmes. Plant and Soil, v.99, p.139-146, 1987.

LEIDI, E.O.; GOMEZ, M.; DE LA GUARDIA, M.D. Evaluation of catalase and peroxidase indicators of $\mathrm{Fe}$ and $\mathrm{Mn}$ nutrition for soybean. Journal of Plant Nutrition, v.9, p.1239-1249, 1986.

LÉON, J.; LAWTON, M.A.; RASKIN, I. Hidrogen peroxide stimulates salicylic acid biosynthesis in tobacco. Plant Physiology, v.108, n.4, p.1673-1678, 1995. 
LEVITT, J. Responses of plants to environmental stresses. New York: Academic Press, 1972. 697p.

LUCAS, R.E.; KNEZEK, B.D. Climatic and soil conditions promoting micronutrient defiencies in plants. In: MORTVEDT, J.J.; GIORDANO, P.M.; LIDSAY, W.L. (Ed.). Micronutrients in Agriculture. Madison: Soil Science Society of American, 1972. p.265-288.

LUMBANRAJA, J.; EVANGELOU, V.P. Acidification and liming influence of surface charge behavior of Kentucky subsoil. Soil Science Society of American Journal, v.54, p.26-34, 1991.

MACFIE, S.M.; TAYLOR, G.J.; BRIGGS, K.G.; HODDINOTT, J. Differential tolerance of manganese among cultivars of Triticum aestivum. Canadian Journal of Botany, v.67, p.1305-1308, 1989.

MALAVOLTA, E.; VITTI, G.C.; OLIVEIRA, S.A. DE. Avaliação do estado nutricional das plantas: princípios e aplicações. Piracicaba: Associação Brasileira de Pesquisa Potassa Fosfato, 1989. 201p.

MARGARIDO, M.A.; SOUZA, E.L.L. Formação de preços da soja no Brasil. Agricultura em São Paulo, v.45, n.2, p.52-61, 1998.

MARSCHNER, H. Mineral nutrition of higher plants. New York: Academic Press, 1986. 649p.

MARSCHNER, H.; DELL, B. Nutrient uptake in mycorrhizal symbiosis. Plant and Soil, v.159, p.89-102, 1994. 
MATHUR, N.; VYAS, A. Changes in isozymes patterns of peroxidase and polyphenol oxidase by VAM fungi in roots of Zziphus species. Journal of Plant Physiology, v.145, n.4, p.498-500, 1995.

McARTHUR, D.A.J.; KNOWLES, N.R. Resistence resposnses of potato to vesicular arbuscular mycorrhizal fungi under varying abiotic phosphorus levels. Plant Physiology, v.100, n.1, p.341-351, 1992.

McARTHUR, D.A.J.; KNOWLES, N.R. Influence of vesicular arbuscular mycorrhizal fungi in responses of potato to phosphorus deficiency. Plant Physiology, v.101, n.1, p.147-160, 1993.

MEDEIROS, C.A.B.; CLARK, R.B.; ELLIS, J.R. Effects of excess aluminium and manganese on growth and phosphorus nutrition of micorrizhal sorghum grown under acid conditions. In: INTERNATIONAL SYMPOSIUM, 3., Dordrecht, 1992. Plantsoil interactions at low pH. Dordrecht: Kluwer Academic Publisher, 1992a.

MEDEIROS, C.A.B.; CLARK, R.B.; ELLIS, J.R. Effects of excess manganese on mineral uptake in micorrizhal sorghum. Journal of Plant Nutrition, v.17, p.22032219, $1992 b$.

MEHDY, M.C. Active oxygen species in plant defense against pathogens. Plant Physiology, v.105, n.2, p.467-472, 1994.

MEMON, A.R.; CHIN, M.; HARA, K.; YATAZAWA, M. Manganese toxicity in fieldgrown tea plants and the microdistribution od manganese in leaf tissues as reveled by X ray micrography. Soil Science of Plant Nutrition, v.27, p.317-328, 1981. 
MENGEL, D.B.; SEGARS, W.; REHM, G.W. Soil fertility and liming. In: WILCOX, J.R. Soybeans: improvement, production and uses. 2.ed. Madison: American Society of Agronomy, 1987. p.461-496.

MINHONI, M.T.A.; CARDOSO, E.J.B.N; EIRA, A.F. Efeitos da adição de fosfato de rocha, bagaço de cana-de-açúcar, fosfato solúvel e fungo micorrízico no crescimento e na absorção de nutrientes por plantas de soja. Revista Brasileira de Ciência de Solo, v.17, p.173-178, 1993.

MIYAZAWA, M.; PAVAN, M.A.; E MARTIN-NETO, L. Provável mecanismo de liberação do manganês no solo. Pesquisa Agropecuária Brasileira, v.28, p.725$731,1993$.

MORAGHAN, J.T. Manganese toxicity in flax grown oncertain calcareous soils low in available iron. Soil Science Society of American Journal, v.43, p.1177-1180, 1979.

MORGAN, P.W.; TAYLOR, D.M.; JOHAM, H.E. Manipulation of AIA oxidase activity and auxin-deficiency symptoms in intact cotton plants with manganese nutrition. Physiology Plantarum, v.37, p.149-156, 1976.

MOSSE, B. Growth and chemical compositions of micorrizhal an non-micorrizhal apples. Nature, v.179, p.922-924, 1957.

MUKHERJEE; S.P.; COUDHURI, M.A. Effect of water stress on some oxidative enzymes and senescence in Vigna seedlings. Physiology Plantarum (Copenhagen), v.52, p.32-42, 1981. 
NAVARRO, R.B.; CARDOSO, E.J.B.N. Simbiose micorrízica pode atuar como agente protetor contra níveis tóxicos de manganês no solo? In: REUNIÃO BRASILEIRA DE FERTILIDADE DE SOLO E NUTRIÇÃO DE PLANTAS, 20., Piracicaba, 1992. Anais. Piracicaba: Sociedade Brasileira de Ciências do Solo, 1992. p.416-417.

NGUYEN, M.N.; LUKASZEWKI, K.; BLEVINS, D. G. IAA oxidase activity in squash roots may be regulated by boron e manganese interaction. Plant Physiology, v.102, n.1, 1993. Supplement, 27.

NOGUEIRA, M.A.; CARDOSO, E.J.B.N. Produção de micélio externo por fungos micorrízicos arbusculares e crescimento da soja em função de doses de fósforo. Revista Brasileira de Ciência do Solo, v.24, p.329-338, 2000.

NOGUEIRA, M.A.; CARDODO, E.J.B.N. Interações microbianas na disponibilidade de Mn e sua absorção por soja. Pesquisa Agropecuária Brasileira, 2002. /No prelo/

OLSEN, S.R. Micronutrient interactions. In: MORTVEDT, J.J.; GIORDANO, P. M.; LINDSAY, W.L. (Ed.). Micronutrients in Agriculture. Madison: Soil Science Society of America, 1972. 666p.

OTA, Y; ARIO, T.; HAYASHI, K.; NAKAGAWA, T.; HATTORI, T.; MAESHIMA, M. ASAHI, T. Tissue-specific isoforms of catalase subunits in castor bean seedlings. Plant Cell Physiology, v.33, n.3, p.225-232, 1992.

PACOVSKY, R.S.; FULLER, G., PAUL E.A. Influence of soil on the interaction between endomycorrhizae and Azospirillum in sorghum. Soil Biology and Biochemistry, v.17, p.525-531, 1985.

PACOVSKY, R.S. Micronuteint uptake and distribution in micorrhizal or phosphorousfertilized soybeans. Plant and Soil, v.95, p.379-388, 1986. 
PACOVSKY, R.S.; BETHLENFAlVAY, G.J., PAUL, E.A. Comparisons between Pfertilized and micorrizhal plants. Crop Science, v.26, p.151-56, 1986.

PACOVSKY, R.S. Metabolic differences in Zea-Glomus-Azospirillum symbioses. Soil Biology and Biochemistry, v.21, p.953-960, 1989.

PALMA, J.M.; ANGELES LONGA, M.; RIO, L.A. del; ARINES, J. Superoxide dismutase in vesicular-arbuscular mycorrizal red clover plants. Physiologia Plantarum, v.87, n.1, p.77-83, 1993.

PENG, S.; EISSENSTANT, D.; GRAHAM, J.H.; KIMBERLYN, W.; HOHGE, N.C. Growth depression in micorrizhal citrus at high phosphorous supply: analysis of carbon cost. Plant Physiology, v.101, p.1063-1071, 1993.

PHILLIPS, J.M.; HAYMAN, D. S. Improved procedures for clearning roots and staining parasitic and vesicular-arbuscular mycorrhizal fungi for rapid assesment of infection. Transactions of the British Mycological Society, v.55, n.1, p.158-160, 1970.

PIMENTEL, C. Metabolismo de carbono na agricultura tropical. Rio de Janeiro: EDUR, 1998. 159p.

PRASAD, M.N.V.; RENGEL, Z. Plant acclimation and adaptation to natural and anthopogenic stress. Annual New York Academy of Science, v.851, p.216-223, 1998.

RAIJ, B. van; SILVA, N.M.; BATAGLIA, O. C.; QUAGGIO, J.A.; HIROCE, R.; CANTARELlA, H.; BELlinAZI Junior, R.; DECHEN, A. R.; TRANI, P.E. Recomendações de adubação e calagem para o Estado de São Paulo. Campinas: Instituto Agronômico, 1985. 107p. (IAC. Boletim Técnico, 100) 
RAJU, P.S.; CLARK, R.B.; ELLIS, J.R.; MARANVILLE. J.W. Mineral uptake and growth of sorghum colonized with VA mycorrhiza at varied soil phosphorous levels. Journal of Plant Nutrition, v.13, p.843-859, 1990.

RICE-EVANS, C.A.; DIPLOCK, A.T.; SYMONS, M.C.R. Techniques in free radical research. Amsterdam: Elsevier Science Publishers BV, 1991. v.22, 291p.

RIDGE, I.; OSBORNE, D.J. Hidroxyproline and peroxidases in cell walls of Pisum sativum: regulation by ethylene. Journal of Experimental Botany, v.21, p.843-56, 1970.

ROSENDAHL, S. Influence of three vesicular-arbuscular mycorrizal fungi (Glomaceae) on the activity of specific enzymes in the root system of Cucumis sativus L. Plant and Soil, v.144, p.219-226, 1992.

ROSS, J. Effects os phosphate fertilization on yield of mycorrhizal and non- mycorrhizal soybeans. Phytopathology, v.61, p.1400-1403, 1971.

ROSSI, C.; LIMA, G.P.P.; HAKVOORT, D.M.R. Atividade de peroxidase (EC 1.11.1.7) e teor de prolina em feijoeiro Phaseolus vulgaris L. cultivado em condições de salinidade. Scientia Agricola, v.54, n.3, p.123-127, 1997.

RUIZ, W.F.R. Atividades de superóxido dismutase, catalases e peroxidase durante o desenvolvimento de micorrizas arbusculares em feijoeiro, sob condições de baixo e alto nível de fosfato. Piracicaba, 1998. 50p. Dissertação (Mestrado) - Escola Superior de Agricultura “Luiz de Queiroz”, Universidade de São Paulo. 
RUIZ-LOZANO, J.M.; AZCÓN, R.; PALMA, J.M. Superoxide dismutase activity in arbuscular mycorrhizal Lattuca sativa plants subjected to drought stress. New Phytologist, v.134, n.2, p.327-333, 1996.

SAFIR, G.R. Water relations. In: SAFIR, G.R. (Ed.). Ecophysiology of VA mycorrhizal plants. Boca Raton: CRC Press, 1987. p.106-147.

SALZER, P.; CORBIERE, H.; BOLLER, T. Hydrogen peroxide in Medicago truncatula roots colonized by arbuscular mycorrhiza-forming fungus Glomus intraradices. Planta, v.208, p.319-325, 1999.

SARRUGE, J.R.; HAAG, H.P. Análises químicas em plantas. Piracicaba: ESALQ, Departamento de Química, 1974.17p.

SCANDALIOS, J.G. Response of plant antioxidant defense genes to enviromental stress. Advances in Genetics, v.28, p.1-41, 1990.

SCANDAlios, J.G. Oxigen stress and superoxide dismutases. Plant Physiology, v.101, n.1, p.7-12, 1993.

SCHAWB, S.M.; MENGE, J.A.; TINKER, P.B. Regulation of nutrient transfer between host and fungus in vesicular-arbuscular mycorrhizas. New Phytologist, v.117, p.387-398, 1991.

SCHNEIDER, E.A.; WIGHTMAN, F. Metabolism of auxin in higher plants. Annual Review Plant Physiology, v.25, p.487-513, 1974. 
SCHUBERT, A.; MARZACHI, C.; MAZZITELLI, M.; CRAVERO, M.C.; BONFANTE-FASOLO, P. Development of total and viableextraradical mycelium in the vesicular-arbuscular mycorrhizal fungi Glomus clarum Nicol \& Schenck. New Phytologist, v.107, p.183-190, 1987.

SEHMER, L.; DIZENGREMEL, P. Contribution to subcellular localization of superoxide dismutase isoforms of spruce needles and oak leaves. Journal of Plant Physiology, v.153, p.545-551, 1998.

SENA, J.O.A. de. Caracterização bioquímica da depressão de crescimento de portaenxertos cítricos inoculados com fungos micorrízicos arbusculares em doses altas de fosfato. Piracicaba, 1998. 111p. Tese (Doutorado) - Escola Superior de Agricultua "Luiz de Queiroz”, Universidade de São Paulo.

SILVA, E.A.A.; PINHO, E. V. R.V.; VIEIRA, M.G.C.; DE CARVALHO, M. L. M.; MACHADO, J.C. Alterações dos padrões de isoenzimas em sementes de milho infectadas por fungos. Pesquisa Agropecuária Brasileira, v.35, n.9, p.1725-1732, 2000.

SPANU, P.; BONFANTE-FASOLO, P. Cell-wall-bound peroxidase activity in roots of mycorrhizal Allium porrum. New Phytologist, v.109, n.1, p.119-124, 1988.

STRIBLEY, D.P. Mineral nutrition. In: SAFIR, G.R. (Ed.). Ecophysiology of mycorrhizal plants. Boca Raton: CRC Pess, 1987. p.59-70.

TANAKA, S.; KONDO, N.; SUGAHARA, K. $\mathrm{O}_{3}$ tolerance and ascorbate-dependent $\mathrm{H}_{2} \mathrm{O}_{2}$ decomposing system in cloroplasts. Plant and Cell Physiology, v.26, p.1425$1431,1985$. 
VALLEJOS, C.E. Enzyme activity staining. In: TANKSLEY, S.D.; ORTON, T.J. (Ed.). Isozymes in plant genetics and breeding: part A. Amsterdam: Elsevier, 1983. p.469-516.

VANACKER, H.; CARVER, T.L.W.; FOYER, C.H. Pathogen-induced changes in the antioxidant status of the apoplast in barley leaves. Plant Physiology, v.117, n.3, p.1103-1114, 1998.

VERKLEIJ, J.A.C.; SCHAT, H. Mechanisms of metal tolerance in higher plants. In: SHAW, J. (Ed.). Evolutionary aspects os heavy metal tolerance in plants. Boca Raton: CRC Press, 1990. p.170-193.

VITÓRIA, A.P.; LEA, P.J.; AZEVEDO, R.A. Antioxidant enzymes responses to cadminum in radish tissues. Phytochemistry, v.57, p.701-710, 2001.

VITTI, G.C.; TREVISAN, W. Manejo de macronutrientes e micronutrientes para alta produtividade da soja. In: CÂMARA, G.M.S. (Ed.). Soja: tecnologia da produção II. Piracicaba: USP/ESALQ, 2000. p.383-422.

WILLEKENS, H.; INZÉ, D.; VAN MONTAGU, M.; VAN CAMP, W. Catalases in plants. Molecular Breeding, v.1, p.207-228, 1995.

WOODBURY, W.; SPENCER, A. K.; STAHMANN, M.A. An improved procedure using ferrycianide for detecting catalase isoymes. Analytical Biochemistry, v.44, n.1, p.301-305, 1971.

YAN, B.; DAI, Q.; LUI, X.; HUANG, S.; WANG, Z. Flooding-induced membrane damage, lipid oxidation and oxygen generation in corn leaves. Plant and Soil, v.79, p.261-268, 1996. 